Gustavo Luiz Frisso

Os circuitos afetivos das narrativas e contranarrativas transnacionais do HIV e da Aids

Dissertação de Mestrado

Dissertação apresentada como requisito parcial para obtenção do grau de Mestre em Relações Internacionais pelo Programa de Pós-Graduação em Relações Internacionais, do Instituto de Relações Internacionais da PUC-Rio.

Orientadora: Profa. Paula Orrico Sandrin

Rio de Janeiro setembro de 2021 


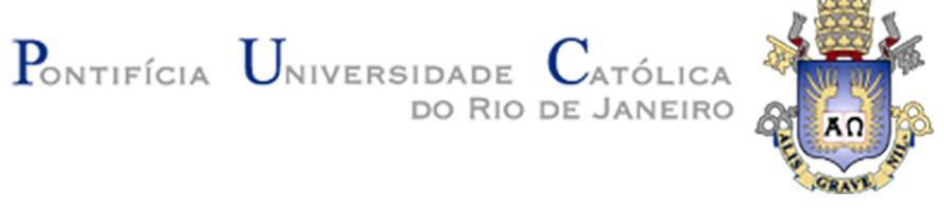

Gustavo Luiz Frisso

\section{Os circuitos afetivos das narrativas e contranarrativas transnacionais do HIV e da Aids}

Dissertação apresentada como requisito parcial para obtenção do grau de Mestre em Relações Internacionais pelo Programa de Pós-Graduação em Relações Internacionais, do Instituto de Relações Internacionais da PUC-Rio. Aprovada pela Comissão Examinadora abaixo:

Profa. Paula Orrico Sandrin

Orientadora Instituto de Relações Internacionais - PUC-Rio

Paula Drumond Instituto de Relações Internacionais - PUC-Rio

Lara Martim Rodrigues Selis Universidade Federal de Uberlândia - UFU 
Todos os direitos reservados. A reprodução, total ou parcial, do trabalho é proibida sem autorização do autor, do orientador e da universidade.

\section{Gustavo Luiz Frisso}

Graduado em Relações Internacionais e Integração pela Universidade Federal da Integração Latino-Americana (UNILA) em 2018. Seus interesses de pesquisa são a construção de narrativas e contranarrativas do HIV e da Aids, a Saúde Global e a Política Externa Brasileira.

Ficha Catalográfica

Frisso, Gustavo Luiz

Os circuitos afetivos das narrativas e contranarrativas transnacionais do HIV e da Aids / Gustavo Luiz Frisso; orientadora: Paula Orrico Sandrin. - 2021.

$153 \mathrm{f.} \mathrm{;} 30 \mathrm{~cm}$

Dissertação (mestrado) - Pontifícia Universidade Católica do Rio de Janeiro, Instituto de Relações Internacionais, 2021. 
A todos os pesquisadores e pesquisadoras do Brasil que, apesar das dificuldades, resistem. 


\section{Agradecimentos}

"O presente trabalho foi realizado com apoio da Coordenação de Aperfeiçoamento de Pessoal de Nível Superior - Brasil (CAPES) - Código de Financiamento 001.”

São tantos rostos, nomes, sobrenomes e lembranças passageiras que eu deveria citar nessa sessão como forma de agradecimento às inúmeras contribuições realizadas ao longo de minha formação. Mas como a sessão de agradecimentos não pode se tornar minha autobiografia de formação de mestre, mencionarei quem foi extremamente essencial para que essa sessão pudesse ser escrita.

Agradeço aos meus pais que, apesar de todas as dificuldades, acreditaram em minha loucura de sair de Foz do Iguaçu e vir estudar no Rio de Janeiro. Serviram de apoio emocional e, principalmente, financeiro em uma época escassa de bolsas para pós-graduação. Sem esse apoio, nessa época de destruição da ciência brasileira, não teria me tornado mestre. Agradeço ainda a minha irmã que foi fundamental nesse diálogo com meus pais, porque alguém precisava convencê-los que vir ao Rio de Janeiro seria uma escolha sábia para minha construção de carreira. Sem todas as nossas conversas e nossos carinhos, eu, definitivamente, não poderia ser quem hoje sou.

Agradeço à professora Paula Sandrin por ter me acolhido quando me senti sozinho. Ela foi fundamental na orientação do trabalho e fundamental na minha própria orientação. Nossas conversas e nossos e-mails me fizeram repensar minha vida inteira. Sua sabedoria, sua personalidade, sua convicção me impulsionaram a uma visão que eu não conseguia enxergar. Nem sempre a jornada pelo processo de mestrado é uma tarefa fácil, mas você me fez acreditar que era possível enxergar um fim. E nosso fim de mestrado, construído nessa dissertação que tenho muito orgulho, é a maior representação que é possível construir diálogos interessantes e importantes quando voltamos a acreditar em nós mesmos. Obrigado, Paula.

Agradeço ao Lucas Guerra, uma peça fundamental para essa realização. Foi ele quem se arriscou, um ano antes de mim, a ingressar no mestrado na PUC-Rio e a construir os sonhos dele. Em nossas conversas em Foz do Iguaçu, ele descrevia o Rio de Janeiro para mim. Descrevia com a riqueza de detalhes o que só um verdadeiro escritor consegue fazer. Motivou-me a buscar novos horizonte e me fez 
acreditar que eu era capaz. E aqui estou, agradecendo-lhe mais uma vez por ter me introduzido nessa loucura e ter me escutado reclamar o tempo todo. Nem todos os sonhos construídos são fáceis de serem vividos. Obrigado, Lucas.

Agradeço ao Rafael Moscardi e ao Mateus Catelan por terem dividido o apartamento 904. Além de excelentes roomates, eram excelentes colegas de mestrado. Ajudaram-me a viver sozinho pela primeira vez. Eles foram fundamentais na minha formação como mestre e na minha permanência no Rio de Janeiro. Obrigado, Galera do Apê.

Agradeço às pessoas da turma de mestrado de 2019 por trazerem considerações tão valiosas às nossas discussões. Apesar de parecer uma pessoa tímida, quieta, pensativa, quero agradecer pela compreensão dos momentos que fiquei em silêncio e por todas as vezes que eu recusei um convite de vocês para sair e beber. De fato, perdi quase todos esses momentos. Obrigado por me acolherem, obrigado por entenderem minhas reclamações sobre o coentro e sobre o Rio de Janeiro. São nossas solidariedades que nos unem!

Agradeço especialmente ao Gustavo Maciel que sempre me escutou e sempre me apoiou em todos os momentos difíceis que passei. Obrigado por acreditar em mim e por me incentivar, cada dia mais, o meu próprio crescimento.

Embora nem todo mundo apareça aqui, sei que muitos foram decisivos e importantes nessa longa jornada. Obrigado infinitamente! 


\section{Resumo}

FRISSO, Gustavo Luiz; SANDRIN, Paula Orrico. Os circuitos afetivos das narrativas e contranarrativas transnacionais do HIV e da Aids. Rio de Janeiro, 2021, 150p. Dissertação de Mestrado - Instituto de Relações Internacionais, Pontifícia Universidade Católica do Rio de Janeiro.

Essa dissertação busca compreender os efeitos e afetos gerados por narrativas e contranarrativas transnacionais do HIV e da Aids, partindo de expoentes da chamada "virada afetiva ou emocional" nas Relações Internacionais que se dedicam ao estudo da circulação de emoções, e da produção de economias afetivas, por meio de narrativas. Partindo do entendimento de que narrativas constituídas por figuras de linguagem, como a metáfora e a metonímia, são produtoras de afecções ou emoções que materializam as superfícies dos corpos individuais e coletivos, serão analisados dois conjuntos de narrativas do HIV e da Aids que desde a década de 1980 tentam fazer sentido da origem do vírus e do estado clínico. No primeiro conjunto, exploraremos como narrativas transnacionais constituídas por metáforas e metonímias como "peste gay", "câncer rosa" e o grupo de risco dos 5Hs (homossexuais, heroinômanos, haitianos, hemofílicos e hookers) se proliferaram, e junto com elas circularam emoções que produziram efeitos de fronteira, afastamento, discriminação e exclusão. No segundo conjunto, exploraremos como outra economia afetiva, impulsionada por contranarrativas que buscam ressignificar as narrativas do HIV e da Aids, é produzida por organizações não governamentais LGBTQIA+, pela UNAIDS, por blogs ou comunidades sociais online, obras cinematográficas, ou testemunhos de personalidades com HIV. Surgida em um contexto marcado por informações mais concretas sobre a infecção e o aparecimento de medicamentos mais eficazes ao controle viral, essa economia afetiva luta contra a sedimentação de emoções negativas em pessoas que vivem com HIV e se vale de estratégias narrativas como a aplicação de novos termos para explicar o HIV e a Aids, a desassociação de termos metonímicos, implicando que o HIV não é Aids e Aids não é morte, e de termos metafóricos, desconstruindo a ideia de "peste gay" ou "câncer rosa". Em uma tentativa de tecer as narrativas do HIV e da Aids com movimentos de contestação e ressignificação da epidemia das 
narrativas, essa pesquisa busca compreender as contranarrativas como imposições urgentes de uma nova construção do que o HIV e a Aids que desfaça efeitos de fronteira e produza possibilidades de afecções outras, que aproximem e conectem.

\section{Palavras-chave}

HIV e Aids; afetos e emoções; narrativas; contranarrativas. 


\section{Abstract}

FRISSO, Gustavo Luiz; SANDRIN, Paula Orrico. The affective circuits of transnational HIV and AIDS narratives and counter-narratives. Rio de Janeiro, 2021, 150p. Dissertação de Mestrado - Instituto de Relações Internacionais, Pontifícia Universidade Católica do Rio de Janeiro.

This master thesis seeks to understand the effects and affects generated by transnational narratives and counter-narratives of HIV and AIDS, based on exponents of the "emotional turn" in International Relations that are dedicated to the study of the circulation of emotions, and the production of affective economies, through narratives. Starting from the understanding that narratives constituted by figures of speech, such as metaphor and metonymy, are producers of affections or emotions that materialize the surfaces of individual and collective bodies, we will analyze two sets of HIV and AIDS narratives that since the 1980s have tried to make sense of the origin of the virus and the clinical condition. In the first set, we will explore how transnational narratives constituted by metaphors and metonyms such as "gay plague", "pink cancer" - associated to the gay community, and the 5Hs risk group (homosexuals, heroin addicts, Haitians, hemophiliacs and hookers) proliferated, and along with them circulated emotions that produced border effects, estrangement, discrimination, and exclusion. In the second set, we will explore how another affective economy, driven by counter-narratives that seek to resignify HIV and AIDS narratives, is produced by LGBTQIA+ non-governmental organizations, UNAIDS, online blogs or social communities, cinematic works, or testimonies of HIV personalities. Appearing in a context marked by more concrete information about the infection and the appearance of more effective drugs for viral control, this affective economy fights against the sedimentation of negative emotions in people living with HIV and uses narrative strategies such as the application of new terms to explain HIV and AIDS, the disassociation of metonymic terms, implying that HIV is not AIDS and AIDS is not death, and of metaphoric terms, deconstructing the idea of "gay plague" or "pink cancer". In an attempt to weave HIV and AIDS narratives with movements of contestation and resignification of the epidemic of 
narratives, this research seeks to understand counter-narratives as urgent impositions of a new construction of what HIV and AIDS is that undoes border effects and produces possibilities of other affections, that bring together and connect.

\section{Keywords}

HIV and Aids; affects and emoticons; narratives; conter-narratives. 
Sumário

1 Introdução

14

2 Construindo caminhos possíveis nas Relações Internacionais ....22

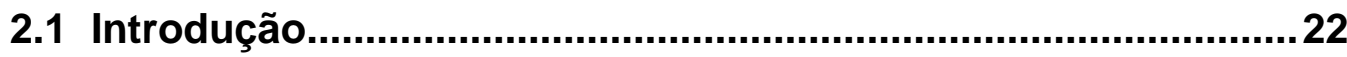

2.2 Metodologias possíveis nas Relações Internacionais:

Autobiografia, Autoetnografia, Narrativas.

24

2.3 A estruturação de narrativas a partir de figuras de linguagem:

metáfora e metonímia como elementos centrais 44

2.4 Uma abordagem estética das Relações Internacionais: os afetos e as emoções nas construções narrativas.............................48

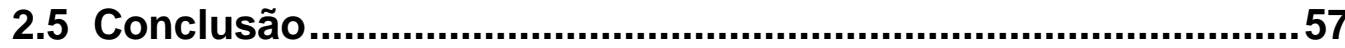

3 As narrativas do HIV e da Aids: a construção narrativa de uma

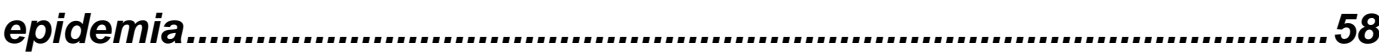

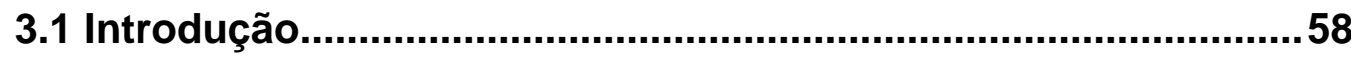

3.2 A doença e o HIV e a Aids como metáforas: narrativas de exclusão sobre corpos infectados ...............................................59

3.3 Outras formas de narrar: as múltiplas faces de uma infecção .86

3.4 Conclusão 104

4 Ressignificando as narrativas de uma epidemia: as contranarrativas do HIV e da Aids.................................................... 105

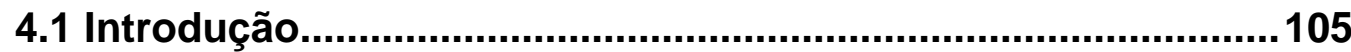

4.2 As contranarrativas do HIV e da Aids ......................................106

4.3 Tecendo Contranarrativas: Sujeitos que Ressignificam o HIV e

a Aids 126

4.4 Conclusão 138

5 Considerações Finais 


\section{Lista de Tabelas}

Tabela I - Pautas no Fantástico sobre o HIV e a Aids ...........................72

Tabela II - Termos que edificam as Contranarrativas...........................123 


\section{Introdução}

Um. Dois. Três amigos. Desconhecidos, conhecidos, escutei falar. Próximos. Distantes. Nos livros, na televisão, nas músicas, nas fotografias. Robert Mapplethorpe, Agenor de Miranda Araújo Neto (Cazuza), Renato Manfredini Júnior (Renato Russo), Caio Fernando Abreu, Farrokh Bulsara (Freddie Mercury), Sandra Bréa, Gaëtan Dugas, Cláudia Magno, Marcus Vinícius Resende Gonçalves (Markito), Michel Foucault, Magic Johnson, Eric Lynn Wright (Eazy-E), Wagner Bello (Etevaldo) que não pôde ir ao Castelo porque estava lá, entre as estrelas, brincando.

Estudar o HIV e a Aids não é nada fácil. Principalmente quando você conhece pessoas que vivem com HIV na sua comunidade afetiva. Você enxerga com seus próprios olhos o impacto das narrativas, das construções metafóricas sobre o vírus, das relações metonímicas sem nenhuma esperança, você entende porque seus amigos estiveram tristes em dias que lhe pareciam normais. Contaram-me de distintas maneiras que viviam com HIV. Um esperou certo tempo para me contar porque acreditou que eu não suportaria as narrativas do HIV e da Aids que lhe atingiram, atingindo a mim indiretamente. Outro me contou logo no início da descoberta do status sorológicos. Como um amigo a quem confia a própria vida, fiz tudo o que estivesse em meu alcance, ainda sem entender tudo o que o HIV e a Aids realmente representavam. Acompanhei-o em sua primeira consulta. Entrei na sala da médica infectologista e ela não parecia preocupada. Tinha um ar sereno, uma fala descontraída, um tom sem julgamento. Para ela, as narrativas do HIV e da Aids já eram conhecidas e seu papel era fundamental nos encontros cotidianos com novas pessoas que vivem com HIV para plantar movimentos contranarrativos. Ela lhe explicou que HIV não era morte e descontruiu as metáforas, principalmente àquelas atreladas a uma vida curta e de sofrimento diário. Era necessário tomar a medicação e fazer exames regularmente para saber se o tratamento surtia efeito desprovido de efeitos colaterais intensos. A partir desse encontro com dois amigos específicos, eu comecei a pesquisar e a entender melhor o que era o HIV e a Aids. Pois, para mim, até aquele momento, não era algo que eu pensava muito. 
Quando precisei escolher um tema para finalizar minha graduação em Relações Internacionais e Integração, o HIV e a Aids tornaram-se uma opção política. A partir da ótica da Cooperação Internacional, estudei a Sociedade Moçambicana de Medicamentos, fruto da parceria cooperativa entre Brasil e Moçambique. Minha perspectiva teórica pautava-se em uma atenção maior à Saúde Global e à cooperação internacional. Naquele momento, não pensei que pudesse me expressar minimamente em meu texto, muito menos dizer o que sentia. Eram realidades diferentes. Se eu quisesse expor minhas manifestações afetivas pela escrita, eu deveria escrever um diário ou rabiscar outros textos, não minha monografia. Quando entrei para o mestrado em Relações Internacionais, eu conheci as viradas afetiva e narrativa na disciplina e entrei em contato com textos tão íntimos, de uma escrita fluída e simples, que me fizeram refletir sobre o fato de escrever na academia. Tentando trazer um pouco das minhas reflexões movidas por meus afetos e emoções ${ }^{1}$, quis construir uma dissertação em primeira pessoa. Claro, escrevendo a introdução depois de ter escrito três capítulos pude notar que não foi uma tarefa fácil. Percebi, principalmente, que escrever em primeira pessoa não era colocar "eu penso" em todas as linhas, em todos os parágrafos, senão deixar marcado essa posição ocasionalmente e deixar sempre presente o que você enxerga com seus próprios olhos. Mas principalmente, agir como um tecelão de narrativas. Tentei trazer uma reflexão íntima em muitos momentos sem transformar esse trabalho em um diário. E se em algum momento houver trechos compreendidos como diário pessoal, então estarei feliz por ter atingido um nível muito intimista de escrita.

Para além de uma introdução de minhas motivações para construir essa pesquisa, preciso apresentar como ela foi construída e porque ela se faz importe na disciplina de Relações Internacionais. Primeiro, precisamos entender o espaço que o HIV e a Aids tomaram majoritariamente dentro da construção de pesquisa acadêmica em Relações Internacionais, em especial compreendendo as abordagens tomadas pelos estudos elaborados. A construção de uma agenda internacional voltada para o campo de saúde influenciou as abordagens para lidar com a Saúde Global, principalmente quando os objetivos são definidos em agendas multilaterais

\footnotetext{
${ }^{1}$ Os afetos e as emoções aos quais me refiro aqui constituem-se parte importante da minha revisão bibliográfica, além de conceitos-chave para discutir toda a minha pesquisa. Ambos serão discutidos no primeiro capítulo.
} 
ou coparticipativas, podendo ser divididas entre aquelas com foco na Segurança e aquelas com foco no bem-estar e nos direitos dos indivíduos (DAVIES, 2010). A agenda de pesquisa sobre o HIV e a Aids não se diferenciou muito dos estudos sobre Saúde Global mencionados por Davies (2010), pois os campos de estudo e desenvolvimento de projetos cooperativos mantiveram-se na Cooperação Internacional e Multilateralismo e Segurança, destacando-se, em cada grande área da disciplina, elementos específicos. A Cooperação em torno do HIV e da Aids relaciona-se muito ao compartilhamento de expertise utilizada na contenção da epidemia, assim como na doação de medicamentos a outros Estados. Dentro dessa seara, em minha monografia, estudei a Cooperação Internacional entre Brasil e Moçambique no intercâmbio de conhecimento qualificado e específico, principalmente aquele conectado à administração da nova instituição farmacêutica em Maputo, a Sociedade Moçambicana de Medicamentos, fruto da cooperação internacional entre dois Estados visando promover tratamento contínuo à população moçambicana e contribuindo com objetivos maiores de controle epidêmico do HIV e da Aids (FRISSO, 2018).

Para meu mestrado, pesquisei artigos que continham as palavras-chave "HIV" e "Aids" em alguns dos principais periódicos de Relações Internacionais, buscando em seus acervos publicações referentes ao tema que pudessem contribuir para a construção de meu projeto inicial. Os periódicos pesquisados foram: International Political Sociology; International Organization; International Security; International Affairs; European Journal of International Relations; Security Dialogue; Review of International Studies; e Cooperation and Conflict. A maioria dos estudos sobre o HIV e Aids encontrados se referiam à questão de Segurança Internacional, ou seja, pretendiam analisar como o HIV e a Aids se tornaram relevantes para as Relações Internacionais por meio de análises sobre conflitos na África (ELBE, 2002; FREEDMAN e POKU, 2005; MCINNES, 2010), na discussão sobre segurança global (PRINS, 2004; ELBE, 2012; MCINNES e RUSHTON, 2012; NUNES, 2014; MCINNES e ROEMER-MAHLER 2017;), na relação de segurança e política externa (MCINNES e LEE, 2006), na biossegurança (KOBLENTZ, 2010), na justiça global (HE, 2007) e na Cooperação internacional (HEINZEN, 1997). Claro, não se tratou de uma pesquisa exaustiva de bibliografias, porém, mesmo utilizando palavras chaves capazes de destacar os tópicos que eu 
procurava, não houve resultados afinados com o tipo de análise que eu pretendia seguir em minha pesquisa.

Tendo contato, durante toda a minha formação de mestre no Instituto, com bibliografias que explorassem além das perspectivas mainstream das Relações Internacionais, conheci novas formas de construir o mundo através da pesquisa. $\mathrm{O}$ encontro com a virada afetiva nas Relações Internacionais foi importante para que eu pudesse compreender como os afetos e as emoções se tornam possíveis guias para distintas indagações sobre o papel das afecções na Política Internacional, principalmente nas relações em torno da epidemia de HIV. Um encontro particularmente importante se deu com Sara Ahmed (2014), uma pesquisadora das emoções e da política internacional. Em sua obra "The Cultural Politics of Emotion", consegui perceber, entre tantas bibliografias com as quais eu tive contato, um estudo e uma reflexão que se destacavam nessas listas bibliográficas infinitas submetidas aos estudantes de pós-graduação. Como as emoções se tornavam relevantes para as Relações Internacionais? Como as emoções nos movem, nos afastam e aproximam? Como as emoções materializam as superfícies dos corpos individuais e coletivos? A partir desse momento, senti uma aproximação dos caminhos que eu desejava trilhar nas Relações Internacionais com uma bibliografia concreta, real e reconhecida dentro do Instituto. Tornou-se um caminho possível. Depois de entender a possibilidade - e compreender as dificuldades e os olhares tortos de adentrar em uma subjetividade íntima como possibilidade de pesquisa na disciplina - busquei outras discussões semelhantes ao trabalho de Ahmed (2014). Conheci os afetos a partir de Safatle (2015). Uma discussão realmente profunda e muito difícil e que me guiou ao mundo dos afetos e das emoções na política internacional, possibilitando o encontro com outros autores trabalhados ao longo dessa dissertação.

Embora os afetos e emoções fossem presentes na minha pesquisa cotidiana, parecia ainda muito distante descobrir essa relação já escrita e publicada em grandes periódicos a partir da perspectiva do HIV e da Aids como questão de Saúde Global. A construção dessa pesquisa, para mim, foi como andar no escuro, porque nas Relações Internacionais parecia impossível descobrir a relação dos afetos e das emoções com o HIV e com a Aids. Somente quando eu tive contato com Susan Sontag $(1984 ; 1989)$, eu consegui traduzir como a pesquisa poderia ser construída: a partir da linguagem, ou, de como a linguagem é a manifestação concreta das 
emoções e indireta dos afetos, assim como ela é responsável por construir narrativas sobre o HIV e a Aids. O estudo das metáforas por Sontag (1989) foi fundamental na definição de como eu poderia inserir essa discussão nas Relações Internacionais. As construções narrativas transnacionais do HIV e da Aids, as metáforas e as metonímias associadas à infecção, pautaram-se no mistério, na incerteza, na exclusão dessas pessoas. Os veículos midiáticos nos Estados Unidos falavam de "peste gay”, "câncer gay” e construíam essas relações místicas acerca das pessoas que viveram com HIV naquela época. Nos primeiros casos de HIV e de Aids no Brasil, a mídia nacional reproduzia grande parte do que a mídia estadunidense construiu. As narrativas do HIV e da Aids começavam a construir no imaginário popular relações semelhantes àquelas construídas nos Estados Unidos, principalmente àquelas que contribuíam para o distanciamento dessas pessoas.

A partir desse recorte, construí uma pesquisa que dialogasse com os afetos e as emoções dentro das Relações Internacionais a partir das narrativas construídas sobre o HIV e a Aids. Dos recortes efetuados, optei por me concentrar no Brasil, mobilizando como fontes trabalhos acadêmicos sobre as narrativas do HIV e da Aids, recortes de histórias de pessoas vivendo com HIV no Brasil e o documentário Cartas para Além do Muro, de André Canto (CARTA PARA ALÉM DOS MUROS, 2019). Compreender as Relações Internacionais a partir dos circuitos afetivos que são colocados em marcha pelas narrativas transnacionais do HIV e da Aids, que afetam e movem sujeitos, é minha contribuição para a disciplina, assim como compreender como podemos construir juntos a ressignificação dessas narrativas por meio do que chamo de contranarrativas do HIV e da Aids². Minha intervenção, portanto, também é sobre ressignificar narrativas que excluem, distanciam e afastam. As Relações Internacionais também precisam ressignificar o HIV e a Aids nas concepções acadêmicas, principalmente porque em todos os debates sobre Segurança e Cooperação, há indivíduos que sentem, são afetados, impactados pelas narrativas do HIV e da Aids, que, mesmo com tantas informações confiáveis sobre a infecção, ainda podem reforçar a atmosfera afetiva da década de 1980 e 1990.

\footnotetext{
${ }^{2}$ Contranarrativa é um conceito que também mobilizo e construo ao longo da minha dissertação. Mas para que se comece a visualizar o que são contranarrativas nessa introdução, explico, brevemente, que esse movimento narrativo surge a partir do contato com as narrativas do HIV e da Aids, e busca ressignificar a epidemia narrativa.
} 
Um dos movimentos naturais da crítica às narrativas geradas sobre o $\mathrm{HIV} \mathrm{e}$ a Aids é o processo de ressignificação e desmistificação da infecção. Desassociar construções narrativas que automaticamente ligam as pessoas que vivem com HIV a elementos depreciativos é fundamental para a desestigmatização e a inclusão. Assim, minha contribuição para Relações Internacionais a partir dessa dissertação se mostra como uma aliada das contranarrativas, dialogando com todas as pessoas interessadas em entender olhares não tradicionais da disciplina sobre o HIV e a Aids e compreendendo como essas narrativas se ressignificam na vida da pessoa que vive com HIV.

Dividi minha dissertação em três capítulos. No primeiro capítulo, eu faço uma discussão teórico-metodológica sobre alguns dos guias que eu utilizei para pensar as Relações Internacionais e entender como trabalhar com o HIV e a Aids pelas perspectivas dos afetos, das emoções, da importância de compreender o mundo a partir dos olhos do outro. Desbravei alguns caminhos sobre as narrativas e o ato de narrar. Compreendi a importância da diferença entre autobiografia e autoetnografia, para relacionar a necessidade de relatos autobiográficos de pessoas vivendo com HIV como fonte de contranarrativas no processo de ressignificação da epidemia do HIV e da Aids. Além disso, construí uma discussão sobre como o Estado, a partir de campanhas e políticas públicas, contribuiu para a expansão da ideia de "grupo de risco" como medida preventiva de saúde pública e acabou reforçando a ideia de grupos de pessoas perigosas à sociedade, criando e reforçando estigmas, além de produzir narrativas de segurança sanitária para as pessoas não enquadradas nesses tais grupos. Também incluo na minha discussão duas figuras de linguagem importantes na constituição das narrativas do HIV e da Aids: as metáforas e as metonímias, responsáveis por edificar uma visão limitada e estigmatizante do HIV e da Aids. Por fim, retomo a importância de meu tema nas Relações Internacionais a partir da virada afetiva na disciplina. Faço-me valer de reflexões estéticas das Relações Internacionais, principalmente na construção e na costura dos afetos e das emoções pelas narrativas da infecção.

O segundo capítulo recupera os elementos metodológicos do primeiro capítulo para descrever como as narrativas do HIV e da Aids ganharam força no momento da expansão transnacional da epidemia. Procuro entender como o HIV e a Aids tornaram-se narrativas repletas de metáforas e de metonímias sobre os corpos e constituíram importantes tópicos nas mídias estadunidenses e brasileiras, 
principalmente porque tornaram-se pautas transformadas em sensacionalismo. Utilizo de Susan Sontag $(1984 ; 1989)$ para compreender como as doenças são metaforizadas a fim de entender a constituição narrativa do HIV e da Aids. Porém, um dos meus focos de análise das narrativas transnacionais da epidemia é a partir do Brasil, entendendo como elas se propagaram na sociedade brasileira e a relação com os veículos de comunicação de grande alcance nas décadas de 1980 e de 1990. Para isso, utilizo o programa Fantástico, da Globo, como peça fundamental para apresentar a Aids e o HIV à sociedade brasileira, tecendo para os lares brasileiros uma narrativa sobre a epidemia que produzia efeitos de fronteira. É importante ressaltar que, embora a dissertação esteja interessada em descobrir as construções de metáforas e metonímias das narrativas do HIV e da Aids, outras formas de narrar a infecção serão apresentadas, dando-nos a possibilidade de repensar como nos foi apresentado o HIV e a Aids. Nessa parte final, discuto pontos importantes construídos a partir das narrativas, a exemplo do futuro, da velhice, dos movimentos queer ressignificando o luto e da questão do estrangeiro. É uma seção importante que busca, evitando qualquer mapeamento completo sobre o tema, introduzir às Relações Internacionais debates importantes sobre o HIV e a Aids.

O terceiro capítulo, por fim, busca trabalhar as contranarrativas, trazendo reflexões pessoais e construindo esse movimento junto com outros autores que descreveram como elas se constituem. Ressalto que os movimentos de contranarrativas são movimentos de ressignificação das narrativas, de desassociação metonímica e de desconstrução metafórica sobre o HIV e a Aids. Na internet, a criação de blogs por pessoas que vivem com HIV como forma de diálogo com novas pessoas que acabam de descobrir seus status tornou-se uma importante fonte de contranarrativa. Compartilhavam-se informações autobiográficas, geravase o sentimento de conexão entre os criadores dos blogs e as pessoas que procuravam por novos olhares sobre a epidemia. Além dos blogs, talvez não muito utilizados hoje, comunidades online no Facebook serviram como plataformas interativas para a troca de experiências sobre viver com HIV. Assim, novos membros são aconselhados e aprendem muito com as pessoas que já vivem com HIV há algum tempo. Essa troca de informações e, consequentemente, a ressignificação conjunta das narrativas do HIV e da Aids constroem e edificam as contranarrativas. Para além desses relatos, trago o documentário, Carta para Além dos Muros (2019), para discutir uma produção audiovisual das narrativas e das 
contranarrativas do HIV e da Aids. Compreender esse processo de ressignificação é fundamental para reinterpretar a epidemia das narrativas.

No final, trago as clássicas considerações finais da dissertação, que além de retomar os principais pontos e reflexões construídos ao longo dos capítulos, pretende construir também alguns possíveis caminhos futuros de pesquisa. Mas, não trago essa agenda de pesquisa apenas para mim, senão construo um diálogo com quem ler minha dissertação e se interessar por essa pesquisa e quiser, com suas próprias palavras, construir contranarrativas do HIV e da Aids em suas pesquisas com seus próprios olhares. 


\section{2 \\ Construindo caminhos possíveis nas Relações \\ Internacionais}

\section{1 \\ Introdução}

Começar é sempre um desafio. Começar por onde eu começo se tornou, para mim, um desafio ainda maior, como se fosse fácil mensurar os desafios. Nesse caso, o desafio que me propus nesse começo é maior que o desafio de simplesmente começar. Adentro em discussões turbulentas nas Relações Internacionais, em que temas não muito tradicionais se fazem presente. Opto por guiar esse capítulo na tentativa de construir, embora mínimo, o meu espaço dentro da academia.

Esse capítulo está dividido em três seções importantes. Na primeira seção, eu discuto metodologias possíveis nas Relações Internacionais, tecendo sobre reflexões acerca da autobiografia, da autoetnografia e das narrativas. Nessa parte, eu quero introduzir temas muito apreciados por mim, além de mostrar a outros pesquisadores em Relações Internacionais possíveis caminhos de pesquisa na disciplina. Adianto que a autobiografia e a autoetnografia, embora muito semelhantes na condução da escrita, diferenciam-se na condução da pesquisa. Enquanto a autobiografia parte do "eu" e como "eu" me insiro no mundo a partir de minhas feridas, a autoetnografia reflete sobre a construção e o debate sobre o "eu" a partir do encontro com o "outro", carregando todas as implicações éticas desse debate e todos os outros desafios envolvidos nesse contato. Acerca das narrativas, preciso frisar que durante toda essa dissertação eu retomarei esse ponto. No capítulo dois e três, eu teço, respectivamente, as narrativas específicas sobre o HIV e a Aids e as contranarrativas, aquelas que de várias formas desestabilizam aas narrativas dominantes e as economias afetivas que põem em marcha. Percebo-me como um pesquisador tecelão. Teço narrativas de pessoas que vivem com HIV com as bibliografias de Relações Internacionais, mas explorando outros caminhos, como as Ciências Sociais, principalmente porque a disciplina de Relações Internacionais se fortalece a partir de olhares multidisciplinares. As narrativas constroem o mundo 
a partir de determinados afetos e emoções, e o sujeito, quando de encontro com essas narrativas, assume uma posição narrativa, acolhendo-as, rejeitando-as, ignorando-as, ressignificando-as. Uma das abordagens narrativas utilizada para falar sobre a construção de narrativas é a política de narratividade, dividida em abordagens extensivistas e intensivistas, que exerceram manejo fundamental no controle da epidemia de HIV, principalmente relacionando o papel do Estado. Porém, as abordagens utilizadas pelo Brasil, por meio dos órgãos de saúde, perpetraram narrativas presentes até hoje sobre o HIV e sobre a Aids. A concepção de "grupos de risco", como estratégia de saúde do Estado para conter a epidemia criou fronteiras entre os indivíduos que vivem com HIV e o restante da população. Os grupos de risco, marco da abordagem extensivista, segregou parte da população, construindo narrativas de condenação para um público-alvo, enquanto propagava concepções errôneas de imunidade contra o HIV para a população que não se encaixava nas definições de grupo de risco. A abordagem intensivista surge como outro marco importante das contranarrativas do HIV e da Aids, empenhando-se em reverter as consequências estigmatizantes da abordagem extensivista, e atribuindo à expansão do HIV através de práticas vulneráveis, não mais grupos específicos.

A segunda seção reflete sobre elementos importantes nas estruturas narrativas, a exemplo das figuras de linguagem e de pensamento, a metáfora e a metonímia. Por meio da articulação de narrativas, e do uso das metáforas e das metonímias, a narrativa sobre o HIV e a Aids esboçou-se a partir de histórias mirabolantes e estigmatizantes sobre a vida e o estilo de vida das pessoas que vivem com HIV. A articulação de metáforas como "a peste gay" ou "o câncer rosa" tiveram grande influência na construção imaginativa sobre a origem do HIV e da Aids. Inclusive, a presença do vírus em homossexuais, haitianos, hemofílicos, heroinômanos e em hookers - profissionais do sexo - construiu uma barreira narrativa sobre quem estava sujeito à infecção e quem não estava. Mas as metáforas e as metonímias, incluídas na construção e no desenvolvimento de narrativas, incomoda-nos.

Assim, a terceira seção desse capítulo busca explorar o incômodo gerado por narrativas sobre o HIV e a Aids, adicionando à discussão perspectivas teóricas sobre os afetos e sobre as emoções. Se de um lado as narrativas são forças que constroem e descrevem o mundo a partir de uma perspectiva - ou de um grupo de perspectivas -, por outro lado, sentimos em nossos corpos, individuais ou coletivos, a influência 
dessas narrativas sobre nossa capacidade de agir diante de algum evento narrativo. A nossa tentativa de traduzir o que sentimos, mesmo por palavras confusas, chamase emoção. Sentimo-nos tristes, felizes, surpresos, medrosos, entre tantas outras formas traduzidas. Mas, o que não se traduz são os afetos. Estão em nossos corpos e circulam em circuitos sociais. As narrativas também acolhem os afetos e as emoções na sua própria constituição e colocam o indivíduo constantemente em contato com o mundo.

\section{2}

\section{Metodologias possíveis nas Relações Internacionais: Autobiografia, Autoetnografia, Narrativas.}

Ceci n'est pas une fiction ${ }^{3}$. Assim como René Magritte pintou em 1929 a ilustre imagem de um cachimbo sobre uma tela, compondo a série de obras conhecidas como La Trahison des Images (1928-1929), e escrevendo por meio de pinceladas “Ceci n'est pas une pipe”, eu inicio minha dissertação afirmando: essa não é uma ficção. Compreender metodologias nas Relações Internacionais pautadas em autobiografia, autoetnografia e narrativas é adentrar-se por discussões turbulentas. Afirmo que não é uma ficção escrever em primeira pessoa e utilizar de reflexões estilísticas (MONTEIRO, 2009) para construir um possível caminho de pesquisa dentro da disciplina. Como já dito por Dauphinee e Inayatullah (2016), independente do termo utilizado - autobiografia, autoetnografia e narrativas - tratase, em suma, de uma não ficção. Optar por esses caminhos metodológicos, ou simplesmente perceber como os únicos viáveis para saciar as inquietações da relação pesquisador/pesquisadora com a escrita de suas pesquisas e reflexões, é, primordialmente, desassociar a condução da pesquisa, da escrita e da estilística da ideia de ficção.

É importante destacar que meu posicionamento em primeira pessoa na pesquisa não é uma forma de escrever literatura, por mais satisfatório seja para mim a escrita ficcional. Inayatullah (1998) coloca as diferenças entre um texto literário e uma prosa científica, reforçando o papel da narração, da sugestão ao invés da

\footnotetext{
${ }^{3}$ Isto não é uma ficção.
} 
argumentação, da responsabilidade de interpretação sobre o leitor e não sobre o escritor, da ausência do modo imperativo em prol da postura modesta e paciente sobre a capacidade de influenciar os leitores (INAYATULLAH, 1998, p. 7). Mais questionador ainda é a relação da intimidade que o eu-pesquisador assume ao retratar na primeira pessoa suas observações. Inayatullah (1998) pergunta: "nós realmente precisamos de uma intimidade tão interna? Continuar com nossas vidas diárias e cumprir nossos projetos de longo prazo geralmente exige que criemos uma distância entre nós e certos problemas terríveis que podem atrapalhar nossas rotinas"4 (INAYATULLAH, 1998, p. 2). Em partes, ao assumirmos o olhar envolvente com a literatura e aderirmos a um olhar semelhante à prosa científica, resolveríamos essas questões do distanciamento com a pesquisa (INAYTULLAH, 1998, p. 6-7). Assim, construo um trabalho científico assumindo as responsabilidades emocionais e afetivas impregnadas em trazer os objetos de pesquisa para uma intimidade interna a fim de compreendê-los, porque eles estavam lá, antes mesmo de eu perceber esse fenômeno. No fim, a relação entre literatura e prosa científica parece ser semelhante nessas três abordagens metodológicas que se inserem na prosa e tornam-se capazes de revelar, em todas suas esferas linguísticas, estéticas, emotivas e afetivas, quem são construídos como os vilões, os homens de bem, os personagens do mundo real constituídos pelo próprio discurso e pelas próprias narrações (INAYATULLAH, 1998).

Aqui, pretendo discorrer sobre como a autobiografia, a autoetnografia e as narrativas funcionam como recursos metodológicos e discursivos sobre a relação com a pesquisa e com a escrita. Adianto que os recursos optados para continuar essa pesquisa respaldam-se, principalmente, sobre a constituição teórica da Narrativa (INAYATULLAH, 1998; AHMED, 2014; INAYATULLAH, 2010; DAUPHINEE e INAYATULLAH, 2016). Nessas construções teóricas, é fundamental compreender que a própria forma de escrita, como escolha particular de manifestação política (CRENSHAW, 1991) não deve se desassociar de seu conteúdo, dos relatos trazidos a partir da perspectiva do sujeito que escolhe construir sua pesquisa por esse caminho. As escolhas tomadas a partir de elementos de estética e de forma participam da pesquisa. Elas importam para contar essa

\footnotetext{
${ }^{4}$ Tradução livre. No original: "Do we really need such an internal intimacy? Carrying on with our daily lives and fulfilling our long term projects often requires that we create instead a distance between ourselves and certain dire issues that may disrupt our routines".
} 
história e é importante para o leitor, para o escritor e principalmente para a intimidade desses casos (COLLINGWOOD, 1963, p. 253 apud DAUPHINEE e INAYATULLAH, 2016, p. 1).

A autobiografia nas Relações Internacionais se contrapõe às intervenções metodológicas das teorias do Mainstream e à própria cadeia positivista de produção do conhecimento, ao mostrar e ressaltar que o escritor, o pesquisador de si próprio, não se encontra distante de seu próprio objeto, ele próprio (DAUPHINEE e INAYATULLAH, 2016; INAYATULLAH, 2010). Nessa tentativa de se desdobrar mais sobre o sujeito que escreve e pesquisa, Inayatullah (2010) busca contrastar essas duas abordagens - autobiografia e autoetnografia - a partir da disciplina: "Por que as Relações Internacionais precisam de um volume como esse?"5 (INAYATULLAH, 2010, p. 5). Ele se questiona, enfatizando a compilação de autobiografias de pesquisadores e pesquisadoras das Relações Internacionais. Mesmo compreendendo que no texto escrito, o escritor se encontra presente porque as ideias necessitam de uma expressão e de uma orientação, o escritor tornou-se ausente na disciplina. Essa ausência, de pronomes ou explicitação das individualidades, qualifica-o como "objetivo e científico" (INAYATULLAH, 2010, p. 5). Pela construção da objetividade e da cientificidade, a escrita tornou-se válida pelo caminho da neutralidade, embora em nada neutro seja essa condução de sua escrita. E inválido se tornou, ou resistente à validação, qualquer tentativa de construção do conhecimento desvinculada à suposta neutralidade da produção do conhecimento, como explica bell hooks (1992), cuja tentativa de construir a teoria como um lugar de cura mostrou-se mais questionador sobre a forma do que sobre o conteúdo. Ela acusou: “estudantes de várias instituições acadêmicas frequentemente reclamam que não podem incluir meu trabalho nas listas de leituras obrigatórias para exames de qualificação para a graduação porque seus professores não o consideram acadêmico suficiente"6 (HOOKS, 1992, p. 7).

\footnotetext{
${ }^{5}$ Tradução livre. No original: "Why does IR need a volume such as this one?". Nota de tradução e aplicação: ao ressaltar "volume", Inayatullah refere-se ao seu livro organizado "Autobiographical International Relations - I, IR" (2010) e busca também considerar dentro da disciplina de Relações Internacionais abordagens metodológicas a partir do "eu", ou seja, considerar os olhares particulares em suas relações com o mundo e com a própria disciplina. Esse compilado torna-se referência para as Relações Internacionais e é um excelente caminho introdutório para aprofundar na metodologia dos estudos autobiográficos.

${ }^{6}$ Tradução livre. No original: "Students at various academic institutions often complain that they cannot include my work on required reading lists for degree-oriented qualifying exams because their professors do not see it as scholarly enough."
} 
A forma de se escrever é totalmente relevante para os objetivos do pesquisador, da pesquisadora, com a escrita. Bell hooks (1992) escreve para engajar os leitores a se envolverem mais e a refletirem mais sobre a prática do feminismo (HOOKS, 1992, p. 8). Ainda, Inayatullah (2010) espera que, por exemplo, bell hooks, escreva como ela escreve, pois como leitores "nós pressupomos que a escrita emerja a partir de um ponto de vista, de um gênero, de uma classe, de uma raça, de uma nacionalidade, de uma herança cultural e de uma biografia"7 (INAYATULLAH, 2010, p. 5). Em contrapartida, a ausência do escritor em sua escrita, mesmo afirmada em princípios metodológicos positivistas, só finge estar ausente, pois os vieses pessoais eliminados pelo discurso da neutralidade estão apenas ocultos dentro e por trás da ciência (INAYATULLAH, 2010, p. 5). Como pesquisadores, não podemos nos encontrar em um espaço para além do mundo e, dessa forma, tentar não fazer parte desse mundo estudado é contraproducente, senão perigoso (INAYATULLAH, 2010). Mas, também ao desvirtuar-se de entendimentos aceitos pela academia sobre a condução da pesquisa científica, corre-se o risco de ser silenciado, como bell hooks apontou incansavelmente (HOOKS, 1992). É com esse dilema que visualizo minha pesquisa dialogar.

Não é por apontar esses três caminhos possíveis de metodologia na disciplina que eu esteja defendendo que, a partir dessa leitura, todos mudem a forma de construir a ciência. Não é sobre essa falsa ideia. É sobre perceber e acolher construções de conhecimento a partir dos sujeitos, colocados e apontados, como fonte de interpretações válidas para compreender a realidade internacional imbricada no indivíduo. Bell hooks (1992) traz a importância de sua teoria, do ato de teorizar, como movimento necessário para a cura de si mesma. Ahmed (2014) aponta as feridas (wound) nos indivíduos a partir das emoções que circulam no seio social, a exemplo da dor, do ódio, do medo, da aversão, da vergonha, e acusa como os afetos e as emoções envolvidos nas feridas individuais são forças progressivas e/ou retrógradas a partir de suas experiências. Ahmed (2014) ainda aponta a teoria das emoções como economia, pois as emoções circulam ou são distribuídas na sociedade, mas também por um campo psíquico e social. Além disso, a inclusão de

\footnotetext{
${ }^{7}$ Tradução livre. No original: "As readers, we suspect that the writing emerges from a point of view, a gender, a class, a race, a nationality, a cultural heritage, a historical specificity, and a biography".
} 
economias afetivas não inclui somente perspectivas de afetos ou de emoções, pois tantos os afetos quanto as emoções são intrinsicamente conectados. Ao falar sobre "economia do medo", Ahmed (2014) exemplifica - ao trazer o refugiado ao centro de sua análise - que o medo manifesta sobre os corpos afetos e emoções que se traduziriam a partir de inúmeras ações contrárias à presença dos refugiados, por exemplo; e como essas ações de exclusão dos refugiados da sociedade articulam a "economia do medo" ao apresentar a circulação social de afetos conectados ao medo e como eles são interpretados na sociedade. Assim, a identificação das feridas em nós mesmos possibilita também a escolha da autobiografia como metodologia possível.

Dessas feridas, Pin-Fat (2016) constrói um caminho possível, sem atribuir valor à escrita acadêmica nas Relações Internacionais, sem questionar se são boas, ruins, singulares, ou o que for, pois a escrita autobiográfica não merece e não deve ser atribuída de valores. A escrita autobiográfica surge despretensiosa de valoração, senão como um autoguia para a construção dos relatos urgentes da pessoa que decide escrever. Embora ela perceba que, a partir do lugar de escrita, das instituições às quais estamos vinculados, espera-se uma pesquisa e, consequentemente, uma escrita de alta performance, de alta qualidade, em padrões líderes de excelência no mundo acadêmico (PIN-FAT, 2016, p. 27). Na construção das pesquisas positivistas, o alto grau de excelência resultava na dissociação do pesquisador com a pesquisa. E retorno a esse ponto inúmeras vezes, porque ele é o cerne da resistência ao acolhimento de novas formas de escritas no mundo acadêmico.

Para Pin-Fat (2016), a autobiografia apoia-se no caráter filosófico do sujeito a partir do encontro com o mundo, com outros, com a forma de (des)comunhão. Ao menos, sua condução autobiográfica buscou refletir qual era o seu compromisso filosófico com "a ética global e, ao mesmo tempo, uma luta com profundo pesar" (PIN-FAT, 2016, p. 35). A morte de seu companheiro se insere e se torna marco na vida de Pin-Fat (2016), e a partir dessa ferida, ela reflete sobre os caminhos adotados entre essa vida privada e essa vida pública, nas distintas formas da pesquisa ser influenciada por fatores pessoais externos aos objetos pesquisados. Reforça que as teóricas feministas escrevem "sobre o lugar do gênero na constituição da multidão de práticas que produzem e policiam uma distinção entre o privado e o público, o pessoal e o político, bem como o pessoal e o publicável 
profissionalmente" ${ }^{\prime \prime}$ (PIN-FAT, 2016, p. 30). A autobiografia permite essa reflexão, esse momento de cura, para que o sujeito enxergue o seu papel diante dos eventos intrínsecos à sua própria existência e o conecte às Relações Internacionais em suas mais diversas manifestações, no seu caso, à academia.

A autobiografia começa para Naeem Inayatullah a partir dos bombardeios no Afeganistão, dos sentimentos brotados diante da realidade intrínseca à sua identidade, e diante da raiva e fúria emergida pela influência desses acontecimentos políticos. Sentiu a necessidade de fazê-lo alvo de suas próprias palavras (INAYATULLAH, 2010, p. 2). Tornou o caminho da autobiografia um caminho da compreensão de seus afetos e emoções e guiou-se por novas formas de tornar-se presente nas Relações Internacionais, de fazer-nos enxergar o que ele viu com seus próprios olhos (INAYATULLAH, 1998). Ao invés de adotar outras formas de construir conhecimento para a disciplina, Inayatullah (2010) preferiu realizar algumas escolhas metodológicas capazes de encaixar a si próprio, junto com os acontecimentos políticos em seu entorno, em um processo de descoberta, ao invés de um processo de contar e exibir uma conclusão (INAYATULLAH, 2010, p. 2). E de uma reflexão sobre a viabilidade de acadêmicos e não acadêmicos encontrarem-se como sujeitos com voz nas relações internacionais. A partir de um comentário notório feito para Naeem Inayatullah, durante uma apresentação autobiográfica sobre os bombardeios no Afeganistão e sobre a vida própria de Inayatullah, comentando-lhe "sua vida é tão interessante", Inayatullah não pôde deixar de se perguntar, "não são todas as vidas interessantes?" (INAYATULLAH, 2010). Na tentativa de conceber a validade de uma autobiografia na disciplina, aproprio-me da reflexão feita pelo autor: todas as vidas são interessantes.

Durante painéis na Conferência da ISA, International Studies Association, Inayatullah (2010) propôs exercícios autobiográficos para seus participantes. As apresentações formaram histórias, confissões e autobiografias. Olhares e ouvidos atentos, parecia existir algo que os unisse, e narrativas que os prendessem (INAYATULLAH, 2010, p. 3). Citando caminhos semelhantes ao adotado, Inayatullah (2010) coloca que através dos pós-colonialismos, feminismos e pós-

\footnotetext{
${ }^{8}$ Tradução livre. No original: "Feminists have long written about the place of gender in constituting the multitude of practices that produce and police a distinction between the private and the public, the personal and the political as well as the personal and the professionally publishable".
} 
estruturalismos, o questionamento expressivo sobre a condução da pesquisa, inclusive o olhar atento sobre o "eu", mostra-se presente (INAYATULLAH, 2010, p. 6). Assim, ele coloca um imperativo sobre seus leitores acerca da recuperação do "eu" e sua demonstração explícita no mundo e na escrita acadêmica. Em sua obra organizada anos depois, influenciada por experiências relevantes de pesquisadoras e pesquisadores durante os painéis da ISA em anos anteriores, a retomada consistente da efetividade da autobiografia como metodologia possível na disciplina é reforçada, inúmeras vezes, ao encarar a realidade teórica dos ensaios a partir das vidas de seus autores, também sujeitos acadêmicos tecelões de conhecimento nas Relações Internacionais. A autobiografia optada por um pesquisador, às vezes nem sempre optada, senão necessária à expressão de suas feridas e de suas descobertas, viabiliza-se como possível ao perceber que sua inserção dentro da Academia de Relações Internacionais também se fundamenta como participação política na disciplina e nas próprias relações com o mundo (AMY, 2010; EDKINS, 2010; PICQ, 2016; PIN-FAT, 2016).

Stephen Chan (2016) reflete sobre a necessidade de transcrever tudo em texto e de torná-lo objetivo dentro da academia, pois torna-se esperado, dos pesquisadores leitores de suas palavras, uma presunção sobre saber o que se fala (CHAN, 2016, p. 16). Embora Stephen Chan (2016) afirme que "você não pode ser um intelectual sem ser um acadêmico", relacionando sua argumentação à própria compreensão imaginária da academia, a respeito da produção e reprodução do conhecimento, dos nomes construídos e reconhecidos a partir de objetos de estudo que lhes associam, bell hooks (1992) discorreu sobre ser intelectual sem necessariamente ser acadêmica. O conhecimento prático, as narrativas de vivência, a perda no horizonte do academicismo desconectado do trabalho prático, abrange tantas intelectuais que não são acadêmicas (HOOKS, 1992). A sensibilidade da condução autobiográfica de nós mesmos - ou a partir de nossas escolhas - preenche uma parte da escrita sobre quem somos, conectando-nos em uma relação micro e macro, do sujeito, consciente de suas feridas, com o internacional (INAYATULLAH, 2010, p. 10-11). No fundo, é sobre cair como um pássaro e alçar voos com suas asas, na metáfora construída por Inayatullah (2010), interpretada por mim como a construção de uma narrativa sobre a liberdade de se movimentar, de pesquisar, de escrever. 
Para Lori Amy (2010), as reflexões sobre a autobiografia também pressupõem a necessidade de nos libertarmos do controle que velhas feridas exercem sobre nós, conjugadas às condições de possibilidade dos encontros com o outro (AMY, 2010, p. 105). A partir do quadro condicionado à possibilidade de escutar o outro, especialmente nossa relação com o outro ou com nosso assunto, viabiliza-se a discussão da autobiografia na academia (AMY, 2010, p. 105). Os elementos da metodologia proposta para atingir esse resultado é exposto a partir da "projeção, identificação, como os assuntos que escolhemos facilitam a pesquisa, e métodos para obter uma compreensão mais profunda e uma distância crítica de nosso passado turbulento",9 (AMY, 2010, p. 105).

Enquanto a autobiografia diz respeito ao sujeito que escreve a partir de suas próprias relações com o mundo, a autoetnografia esboça-se como metodologia nas Relações Internacionais a partir de uma série de dilemas éticos colocados diante do pesquisador (DAUPHINEE, 2010). A autoetnografia é discorrida por Dauphinee (2010) a partir de seu encontro com o outro. Com muitos debates compartilhados com a construção da autobiografia, principalmente no que diz respeito à relação do pesquisador com a escrita, a reflexão sobre a autoetnografia, como metodologia viável a partir do encontro com o outro e como as narrativas do outro influenciam as narrativas do pesquisador, sempre considera que as narrativas do pesquisador poderão surgir como narrativas violentas a partir desse encontro (DAUPHINEE, 2010), por isso, questões éticas são apresentadas para guiar esse encontro.

$\mathrm{Na}$ disciplina, também dentro da perspectiva da autoetnografia, existe uma constante invisibilização do "eu" (self), sendo desafiada constantemente por "novas" abordagens, embora o "eu" sempre estivesse presente (DAUPHINEE, 2010, p. 799). Ao mesmo tempo, a sua construção teórica sobre a autoetnografia busca blindar, dentro e fora da academia, concepções rasas que associam unicamente a autoetnografia, diria também sobre a autobiografia, à elaboração da "frase mais bonita"10 (DAUPHINEE, 2010, p. 799). Essa crítica em relação à estilística não se funda no vácuo. Técnicas usadas por romancistas e refletidas por acadêmicos sobre o processo de escrita influenciam no processo autobiográfico e

\footnotetext{
${ }^{9}$ Tradução livre. No original: "My opening vignette suggests some of the ways that auto/biography and our work converge: projection, identification, how the subjects we choose facilitate research, analysis, methods for gaining both a deeper understanding of, and a critical distance on, our troubled pasts."

${ }^{10}$ Tradução livre. No original: "The prettiest sentence".
} 
autoetnográfico, porque a estilística, referindo-se à escolha estilística do texto, é caracterizada "por uma intenção expressiva, carregando-se de valores afetivos e evocatórios” (MONTEIRO, 2009, p. 7). Pela junção da estilística à teoria literária, a concepção de que a forma e o estilo da escrita refletem o gênero do texto, desvios sobre a conduta da autobiografia e da autoetnografia se fazem presentes e são criticados por Dauphinee (2010) e Inayatullah (2010), que apontam para o risco de perceber essas duas abordagens como desprendidas do construir e escrever conhecimento dentro da disciplina. Esses desvios de conduta se referem à intencionalidade de escrever ficção, que estaria contrária a perspectiva de construir conhecimento a partir das reflexões e dos olhares do "eu" enquanto pesquisador de mim mesmo - autobiografia - e do "eu" enquanto pesquisador que se preocupa e conduz a sua pesquisa a partir da ética estabelecida para essa construção - a autoetnografia. Ou seja, há um movimento de validação do conhecimento a partir de escritas concernentes à construção estilística e a pensamentos contrários à realidade ficcional escrita em primeira pessoa e intencionada como ciência.

Assim, um dos primeiros limites éticos adotados por Dauphinee (2010) é explorar as limitações da voz acadêmica e seu impacto no que escrevemos, nas verdades que reconhecemos e sobre as quais escrevemos, nos caminhos por meio dos quais a voz acadêmica silencia o "eu" (self), em compreender quem é forçado a esconder ou minimizar as próprias e frequentes motivações pessoais por engajar na disciplina (DAUPHINEE, 2010, p. 799). Considerando os espaços de nossas próprias vozes acadêmicas a partir da autoetnografia, Dauphinee (2010) narra a construção de sua carreira com a vida e a perda de um homem chamado Stojan Sokolovic, mobilizado para uma guerra que ele não começou, nem queria participar (DAUPHINEE, 2010, p. 800). Desse encontro com o outro, ela o escutou e transcreveu reflexões importantes sobre a guerra na Bósnia. Quais as limitações da voz acadêmica com a voz do outro? Dessa pergunta, Stojan Sokolovic questiona Dauphinee sobre suas próprias escaladas de violência, colocando que "você escreve sobre violência, você diz que o medo é uma violência - que as coisas que causam medo e insegurança são violências. Mas você não sabe que o medo se instala como um urso em meu coração"11 (DAUPHINEE, 2010, p. 800). Sobre as relações do

\footnotetext{
${ }^{11}$ Tradução livre. No original: “'You write about violence', he said. 'You say that fear is a violence - that the things that cause fear and insecurity are violences. But you do not know how that fear sits like a bear on my heart".
} 
Internacional na Guerra da Bósnia, a participação e a atuação do corpo diplomático da ONU e da OTAN, sobre as análises de atores realizadas pelas correntes mainstream da disciplina, um homem esteve no caminho de Dauphinee e lhe questionou sobre a sua própria voz diante de ele próprio, colocando-se na sua relação com o mundo, e levando-a a questionar-se sobre o caminho viável para registrar esse encontro e torná-lo válido na academia, ao invés de contabilizá-lo, mais tarde, apenas como um ator não influente de uma guerra. E sobre isso, Dauphinee (2010) se questionou e interpôs que a disciplina das Relações Internacionais se construiu sobre as mortes e as perdas alheias (DAUPHINEE, 2010, p. 802). Como construir uma pesquisa autoetnográfica sem considerar as possíveis violências sobre o outro, sem deslegitimar a importância do "eu" na construção da pesquisa, mas sem torná-lo o foco-guia da pesquisa? Assim, enquanto a autobiografia registra os impactos do mundo sobre o "eu", a autoetnografia incorpora e considera as implicações éticas do contato com o outro sobre o "eu" (INAYATULLAH, 2010; DAUPHINEE, 2010; DAUPHINEE e INAYATULLAH, 2016).

Dauphinee (2010) busca se proteger através da condução autoetnográfica da tradição positivista de produção de conhecimento que nega todos os traços do "eu" na escrita acadêmica e disciplinar (DAUPHINEE, 2010, p. 803). Nas Relações Internacionais, assume-se certo elemento de veracidade em suas históricas documentadas, principalmente quando guiados por preceitos positivistas, deixando de fora dessa mesma narrativa outros documentos e expressões orais (DAUPHINEE, 2010, p. 810). Essa presunção de Dauphinee (2010) é válida para reforçar que a partir de metodologias acadêmicas aceitas, os dados coletados e relatados pelo pesquisador são tão suspeitos quanto qualquer expressão autoetnográfica. Inclusive, para Dauphinee, essas abordagens aceitas são ainda mais suspeitas porque a autoetnografia não pretende ser mais do que é: a reconfiguração do "eu", compilando as informações e fazendo o conhecimento (DAUPHINEE, 2010, p. 812-813). Por observar caminhos possíveis na construção da pesquisa, a autoetnografia não está livre de algum método para julgar suas atribuições, nem livre de armadilhas e dilemas como ser compreendida erroneamente como uma abordagem com frases bonitas e com intenção de formar uma geração de romancistas na academia (DAUPHINEE, 2010, p. 817). A autoetnografia não busca reduzir-se a uma questão estética, embora a estética da 
construção das frases carregue intencionalidades por parte do autor/escritor a fim de causar rebuliços em seus leitores, colocá-los a compreender os problemas levantados pelos afetos e emoções, impulsioná-los a observar escritas possíveis na academia (AHMED, 2014; MONTEIRO, 2009; DAUPHINEE, 2010).

Por fim, a autoetnografia respalda-se também na compreensão dos silenciamentos. Se por um lado, a autoetnografia permite ouvir as perguntas feitas, respondê-las, e quebrar a distância ilusiva entre o "pesquisador" e o "pesquisado", por outro lado, compreende-se como violência por parte do pesquisador ao não observar o narrador de suas histórias - a pessoa que está respondendo às perguntas - como inteligível, esperando uma erradicação dessa experiência do artigo, livro, ensaio ou palestra (DAUPHINEE, 2010, p. 809). Os limites éticos da autoetnografia levantam questões importantes para o trabalho de escuta, de reflexão e de escrita. Assim, existe uma consciência reflexiva de si mesmo como "um perpetrador de um certo tipo de violência no curso de todos os escritos e de todas as representações uma violência, aliás, que não pode ser evitada"12 (DAUPHINEE, 2010, p. 806). Ao refletir sobre as escolhas adotadas na condução da pesquisa e da escrita autoetnográfica, essa abordagem pode contribuir para a identificação de violências menores, pois, ao não escutar as narrativas alheias, seja pela incapacidade de falar, seja pela incapacidade de não as considerar como plausíveis à pesquisa, o silenciamento ainda se mantém presente, embora escondido pelo próprio pesquisador.

Em suma, a possibilidade da autoetnografia, após a reflexão sobre as implicações éticas envolvidas na abordagem, reforça-se a partir da ideia de que "a forma e o conteúdo da escrita contemporânea nas Relações Internacionais não são automáticas, ou necessariamente as únicas maneiras valiosas de conduzir uma vida acadêmica orientada para a pesquisa"13 (DAUPHINEE, 2010, p. 818). Assim como apresentado na descrição sobre a autobiografia e as possibilidades de sua representação na academia pelas escritas e pelas conduções da pesquisa - pois, compreender a si próprio, nessa relação sujeito-mundo, também ilustra

\footnotetext{
${ }^{12}$ Tradução livre. No original: "a perpetrator of a certain kind of violence in the course of all writing and all representation - a violence, incidentally, that cannot be avoided".

${ }^{13}$ Tradução livre. No original: "Autoethnography is one way through which we are reminded that the form and content of contemporary writing in IR are not automatically or necessarily the only valuable ways to conduct a scholarly, research-oriented life".
} 
representações importantes para compreender partes da disciplina não alcançadas por outras abordagens - a autoetnografia se expande por caminhos semelhantes, sendo, inclusive, compreendida como sinônimo para a autobiografia (INAYATULLAH e DAUPHINEE, 2016). Dessa forma, adotar a autoetnografia como metodologia possível na disciplina é compreender os riscos "de ver mais do que nós ignoramos, tanto em nós mesmos quanto nos outros, levantando as razões pelas quais nós ignoramos, e o que poderíamos fazer sobre isso"14 (DAUPHINEE, 2010, p. 818).

Acredito que seja muito válido ter discorrido sobre as abordagens autobiográficas e autoetnográficas como metodologias possíveis. A abordagem escolhida para compor parte de minha pesquisa se refere mais aos preceitos da autobiografia do que da autoetnografia. Essa, embora não circunde o trabalho como metodologia inclusa para guiar minhas reflexões, mostra-se válida na complementação e diferenciação com a autobiografia. Assim, diferenciá-las e ressaltá-las como distintos caminhos para a inclusão do "eu" nas Relações Internacionais foi um de meus objetivos nesse capítulo. A inclusão da perspectiva autobiográfica estará presente em outras partes desse trabalho, principalmente quando eu manifestar meus afetos e minhas emoções em relação às narrativas e às contranarrativas do HIV e da Aids. Além de se tornarem essenciais como manifestações individuais e coletivas na expansão de contranarrativas. Ainda, parece-me fundamental discorrer sobre as abordagens autobiográfica e autoetnográfica como metodologias possíveis de pesquisa e trabalhá-las juntas, explicando suas nuances. A descoberta dessas duas abordagens representou um importante momento para mim, o momento em que eu descobri que a escrita acadêmica poderia se conectar diretamente com minhas experiências no mundo.

Apresentei duas abordagens metodológicas possíveis para a condução de pesquisas nas Relações Internacionais e, agora, pretendo tecer sobre as narrativas como um emaranhado metodológico para a condução da pesquisa, de conceitos, de reflexões, sem excluir as singularidades das representações na escrita acadêmica. Mas, antes de continuar, preciso discutir dois termos importantes para o resto da

\footnotetext{
${ }^{14}$ Tradução livre. No original: "The risk of autoethnography opens us to the possibility of seeing more of what we ignore in both ourselves and others, asking why it is ignored, and what we might need to do about it."
} 
dissertação: emaranhado e tecer. Assumo-me como um pesquisador que tece narrativas nas Relações Internacionais. Tecer (vtd), de acordo com dicionário Aurélio, significa: "1. Entrelaçar regularmente os fios de. 2. Fazer (teia ou tecido) com fios. 3. Engendrar, armar. 4. Compor, entrelaçando. 5. Fig. Compor (obra que exige trabalho e cuidado). int. 6. Exercer o ofício de tecelão. p. 7 Enredar-se" (FERREIRA, 2010). Mas, ao invés de trabalhar com fios, eu trabalho com narrativas. Minha intenção é entrelaçar as narrativas sobre o HIV e a Aids com narrativas de pessoas vivendo com HIV para construir esse trabalho. As narrativas, dessa forma, ilustram a relação sujeito-mundo para o pesquisador, sem que ele faça parte desse processo diretamente, tornando-o um tecelão das narrativas contatadas, permitindo-o enxergar, ao menos, o que os sujeitos das narrativas viram com seus olhos (INAYTULLAH, 1998). Assim como o tecelão é responsável por desemaranhar os fios e transformá-los em tecido, o pesquisador, que opta por abordar as narrativas, torna-se responsável por desemaranhá-las e transformá-las em uma escrita menos confusa, coerente e coesa com a profundidade e complexidade envolvida no ato de narrar as histórias alheias.

Retomo uma reflexão feita por Dauphinee (2010), na qual ela sugere que a disciplina de Relações Internacionais é formada por narrativas que contam história do passado e de teorias construídas em cima de eventos internacionais repletos de narrativas (DAUPHINEE, 2010, p. 809). As narrativas seguem "convenções de história, como o uso de enredos comuns, sequências temporais lineares ou caóticas e escrita dentro/contra gêneros de textos"15 (DAUPHINEE, 2010, p. 807). Observo a existência de limites entre os tipos de narrativas. Uma narrativa pode se originar a partir da relação do sujeito com o mundo, assim como uma narrativa sobre o mundo pode influenciar a própria relação do sujeito com o mundo. Sobre isso, ilustro o caso das narrativas sobre o HIV e a Aids. Existem as narrativas que constituíram o imaginário da infecção (SONTAG, 1989; AHMED, 2014; BARATA, 2006; PASSOS e BARROS, 2009) e existem as narrativas do sujeitomundo inserido em um mundo repleto de narrativas, constituídas por metáforas e metonímias, construídas sobre o HIV e a Aids (SONTAG, 1989; TIMERMAN e

\footnotetext{
${ }^{15}$ Tradução livre. No original: "both stories and narratives proceed along 'storying conventions such as the use of common storylines, linear or chaotic temporal sequences, and writing within/against genres".
} 
MAGALHÃES, 2015; CARTA, 2019). Ou seja, existem as narrativas construídas sobre o HIV e a Aids e as narrativas construídas a partir do encontro desses sujeitos com essas narrativas. Enfatiza-se o que está em jogo aqui não é a veracidade objetiva de qualquer afirmação particular, mas sim a questão de como essa veracidade é gerada e por quem (DAUPHINEE, 2010). Assim, engajo as narrativas com o objetivo partilhado por Inayatullah (2010): “mover o campo das Relações Internacionais para uma maior franqueza sobre como as narrativas pessoais influenciam as articulações teóricas""16 (INAYATULLAH, 2010, p. 6).

Para construir parte do caminho das narrativas nessa dissertação, considero essencial compreender a política da narratividade, que empreende o papel do pesquisador enquanto obstinado a abordar a Saúde, e a forma pela qual se constitui como força social. Ao estruturar uma dissertação respaldada em um importante segmento da Saúde Global, não posso desassociar a constituição das narrativas com a política da narratividade utilizada do campo da pesquisa em saúde (PASSOS e BARROS, 2009). A base da política da narratividade se forma a partir de diferentes técnicas, a exemplo de entrevistas, questionários, grupos focais, observação participante e elas demonstram maneiras de narrar, tanto pelos sujeitos das pesquisas quanto pelo próprio pesquisador, elaborando, no fim de cada atividade, as análises e conclusões de acordo com certa posição narrativa (PASSOS e BARROS, 2009, p. 150). No livro "Histórias da Aids" (TIMERMAN e MAGALHÃES, 2015), pelo qual recuperarei as contranarrativas sobre o HIV e a Aids, o registro das narrativas se divide em dois momentos importantes. O primeiro, refere-se à política da narratividade descrita por Passos e Barros (2009), quando as narrativas ganham escopo a partir de entrevistas. O segundo momento, contribuindo com a abordagem autobiográfica, os escritores escrevem suas posições como médicos trabalhando diretamente com pacientes vivendo com HIV.

A política da narratividade é expressa como "uma posição que tomamos quando, em relação ao mundo e a si mesmo, definimos uma forma de expressão do que se passa, do que acontece. Sendo assim, o conhecimento que exprimimos acerca de nós mesmos e do mundo não é apenas um problema teórico, mas um problema político" (PASSOS e BARROS, 2009, p. 151). Dessa forma, assim como os

\footnotetext{
${ }^{16}$ Tradução livre. No original: "Our goal is to move the field of International Relations towards greater candidness about how personal narratives influence theoretical articulations".
} 
discursos são fenômenos sociais, unindo os indivíduos e os capacitando a se envolver, interagir e funcionar socialmente (EPSTEIN, 2008, p. 2), a construção e a compreensão das narrativas também se ilustram como fenômenos sociais e políticos, representando sujeitos, sociedades e estados, narrando-os com seus modos de vida e do mundo ao seu redor (EPSTEIN, 2008).

A política da narratividade sobre o HIV e a Aids percorreu duas análises distintas sobre a explicação da infecção a partir da perspectiva do Estado como articulador do Sistema Público de Saúde para prevenir a manifestação descontrolada do vírus no país (PASSOS e Barros, 2009). Ressalto que as abordagens extensivistas e intensivistas enquadram-se no campo da pesquisa de saúde e se referenciam a partir da escala adotada de observação, enquadrando, por exemplo, a questão de saúde debatida em uma macro ou microescala (MAIA e NEVES, 2014). A questão de compreender essas abordagens, seja macro ou seja micro, é analisar quais são as questões envolvidas no processo decisório e nos planos adotados para o enfrentamento de uma epidemia. As questões macro se referenciam principalmente a partir da abordem extensivista, que busca em sua extensão uma resposta imediata. Como observado por Passos e Barros (2009) a partir da observação extensivista do combate à epidemia, nota-se que

\begin{abstract}
em 2006, por exemplo, o Programa Nacional (PN) de DST/Aids do Ministério da Saúde conseguiu garantir R\$ 1 bilhão do orçamento para a compra de medicamentos antirretrovirais, cobrindo 170 mil brasileiros, $100 \%$ dos pacientes, que estão com AIDS e que são atendidos no SUS - isso equivale a $0,1 \%$ da população brasileira, sendo que hoje a taxa média de prevalência dos infectados está entre $0,61 \%$ no Brasil. Poderíamos, numa primeira aproximação afirmar aí a ação de um programa cujo método é extensivista. (PASSOS e BARROS, 2009, p. 152)
\end{abstract}

No caso da resposta ao HIV e à Aids, a abordagem se pautou na contenção epidêmica, desprezando as consequências geradas a partir dessa escolha. Embora tenha sido uma ruptura social, a partir da estigmatização das pessoas definidas como "grupo de risco", essa abordagem representou a maior cobertura possível diante do HIV (PASSOS e BARROS, 2009). Ainda pautado em uma questão extensivista, pouco se obteve a partir de campanhas publicitárias "quando a palavra de ordem 'use camisinha' se impôs nos anos 80 com o advento do risco do HIV. Como nos alerta Ayres (1996, apud PASSOS e BARROS, 2009, p. 16) os "conceitos de fator, 
grupo e comportamento de risco (...) têm servido de base para sucessivas estratégias de conhecimento e controle epidemiológico" (PASSOS e BARROS, 2009, p. 152).

Assim, ilustrando a abordagem extensivista, percebe-se que "a máquina do Estado é convocada a realizar diante da amplitude da nação, o método por ser aquele que impõe determinado procedimento por força da lei” (PASSOS e BARROS, 2009, p. 151-152). Para garantir esse controle do Estado sobre a epidemia, utilizouse de conceitos como "fator", "grupo" e "comportamento" de risco como base para estratégias de conhecimento e controle epidemiológico. Entretanto, como nos mostra os autores, "o conceito risco tem, frequentemente, apresentado 'custos' técnicos, sociais e políticos superiores a seus benefícios" (PASSOS e BARROS, 2009, p. 152). A partir da abordagem extensivista, o Estado articula uma narrativa sobre o HIV e a Aids pautada em limites sobre a infecção, como se ela apresentasse limites tão nítidos logo no começo. Ao circular alguns grupos e classificá-los como "grupos de risco", a narrativa criada fora desses grupos é: I- existe uma proteção para todos aqueles excluídos dos grupos, fatores ou comportamentos de "riscos"; II- compreende-se uma exclusão dos indivíduos desses "grupos de risco" da sociedade porque, de alguma forma ou de outra, eles se desvinculam do caráter ético e moral preexistente na sociedade. Assim, Passos e Barros (2009) perceberam que os custos derivados da classificação de "risco" incluem em preconceito, estigmas, além da pouca atenção para questões que poderiam a todos atingir, como é o caso do HIV e da Aids (PASSOS e BARROS, 2009). Ficava-se claro que a abordagem deveria mudar porque para além da extensão material, através do fornecimento de tratamento e de métodos preventivos amplamente difundidos, independente do resultado alcançado, expandiam-se narrativas que estigmatizavam certos grupos da população.

Um dos resultados do mapeamento sobre as pessoas infectadas pelo vírus do HIV ou já desenvolvendo o estado clínico da Aids em seus corpos na década de 1980, principalmente nos Estados Unidos, narrou a classificação de pessoas vivendo com HIV pertencentes a um desses cinco grupos: Homossexuais, Hemofílicos, Haitianos, Heroinômanos e Hookers $^{17}$ (TIMERMAN e MAGALHÃES, 2015). Enquanto uma das primeiras abordagens de compreensão sobre quem eram as pessoas vivendo com HIV nos Estados Unidos, e a constituição

\footnotetext{
${ }^{17}$ Gíria, em inglês, que designa as profissionais do sexo (TIMERMAN e MAGALHÃES, 2015).
} 
sucessiva de narrativas que resultou na definição de 5 grupos específicos, no Brasil, narrativas transnacionais influenciadas pela mídia estadunidense já constituíam os personagens das narrativas daqui. Ressalto ainda que o Estado brasileiro, ao invés de adotar as classificações presentes na mídia estadunidense e, consequentemente, na mídia brasileira, optou por construir uma política de narratividade menos direcionada a partir da criação do termo "grupo de risco". Mas, ao tirar o foco da expansão da epidemia sobre os $5 \mathrm{Hs}$, a política de narratividade extensivista não eliminou efeitos de fronteira sobre as pessoas que vivem com HIV. Isso porque, ao criar o termo "grupo de risco", na tentativa de fugir do foco midiático sobre os $5 \mathrm{Hs}$, a fronteira entre as pessoas que vivem com HIV foi somente redesenhada. O desembaraçamento narrativo de "grupo de risco" levou à sociedade a entender ainda que se tratavam de pessoas específicas, com comportamentos específicos e que, no fim, essas pessoas eram conhecidas: os homossexuais, os hemofílicos, os heroinômanos e os/as profissionais do sexo, embora tenha desaparecido das narrativas brasileiras a perspectiva sobre os haitianos (BARATA, 2006; TIMERMAN e MAGALHÃES, 2015). Existem narrativas em volta de cada uma dessas classificações e nem todas as narrativas buscaram prevenir a infecção; algumas buscam excluir esses sujeitos do seio social. As primeiras narrativas sobre o HIV e a Aids se construíram a partir da incompreensão científica em torno do vírus, em especial a construção metafórica de que se tratava de um enigma e de um mistério até mesmo para os cientistas (BARATA, 2006), e de seus efeitos e do sensacionalismo midiático. Enquanto a mídia já batizava a nova enfermidade como “câncer gay” ou "câncer rosa”, por causa das características até então identificadas, no meio acadêmico começou-se a adotar a sigla DIRG, designando a Doença Imunológica Relacionada aos Gays (DIRG) (BARATA, 2006; TIMERMAN MAGALHÃES, 2015).

Embora a adoção por parte do Estado, também construtor de narrativas, do combate à epidemia ter se orientado, a princípio, sobre a abordagem extensivista, ou seja, a partir de um recorte direcionado de atuação para a contenção epidêmica desconectada de qualquer preocupação de possíveis consequências sociais, impulsionando a manifestação de distintas narrativas sobre o HIV e a Aids e seus "grupos de risco", a adoção nos anos posteriores da abordagem intensivista - a abordagem que visou desestigmatizar as consequências narrativas causadas pela abordagem extensivista - buscou reverter as consequências das narrativas já em 
voga, ressignificando as narrativas criadas dos grupos de risco (PASSOS e BARROS, 2009, p. 152). Essa resposta oriunda da abordagem intensivista se deve majoritariamente ao fato de que a condução intensivista trabalha com uma postura ético-política como pilar condutor (PASSOS e BARROS, 2009; MAIA e NEVES, 2014). Assim, tentando consertar os "custos técnicos" provocados pela abordagem extensivista, a abordagem intensivista começou a trazer ressignificações para a questão do HIV e da Aids no país. Todavia, não se pode dizer que as campanhas de combate à manifestação do HIV e da Aids tenham se pautado exclusivamente na abordagem extensivista, ou totalmente na abordagem intensivista. $\mathrm{O}$ sucesso, em partes, do controle da epidemia de HIV no Brasil se deu à execução das duas abordagens, embora as consequências sociais tenham permanecido nas narrativas da infecção. Compreendendo os efeitos dessa maneira de narrar a infecção, e de como essa prática narrativa produziu e modificou subjetividades a partir dos critérios marcados pelo pertencimento e pela identificação de alguns grupos sociais incluídos como suscetíveis ao "risco", observou-se uma reformulação da abordagem guiada pelo Estado nas suas diretrizes e nos seus órgãos de saúde, que se concluiu na compreensão intensivista. Uma das principais viradas narrativas do combate ao HIV e à Aids pela abordagem intensivista foi a aquiescência dos custos políticos e sociais do limite excludente de "risco" como categoria de prevenção. A abordagem intensivista se organizou como "um trabalho de capilarização, de transversalização e de criação de novos modos de produzir saúde e sujeitos e de outras maneiras de narrar a experiência de cuidado no campo das DST/AIDS" (PASSOS e BARROS, 2009, p. 153). Dessa forma, o Brasil articula uma política de narratividade ao fazer do conceito de "vulnerabilidade", em substituição ao "risco", como um eixo organizador das ações preventivas, dissolvendo a dimensão identitária e de pessoalidade que a noção inicial impunha (PASSOS e BARROS, 2009, p. 153-154). De todo o modo, a noção construída e estabelecida pelo termo "vulnerabilidade" implica deslocar a relação naturalizada infecção/indivíduo para acrescentar novas questões em diálogo com o termo: fala-se de vulnerabilidade estrutural, social, programática, além da individual (PASSOS e BARROS, 2009, p. 154). A adoção do termo vulnerabilidade também se refere 


\begin{abstract}
AIDS. Os fatores subjacentes à vulnerabilidade podem reduzir a capacidade de indivíduos e comunidades de evitar o risco de infecção pelo HIV, e podem estar fora do controle dos indivíduos. Tais fatores podem incluir: a falta de conhecimentos e habilidades necessários para se proteger e proteger os outros; acessibilidade limitada, qualidade e cobertura dos serviços; e fatores restritivos na sociedade como violações de direitos humanos, leis punitivas ou normas sociais e culturais prejudiciais (incluindo práticas, crenças e leis que estigmatizam e desempoderam determinadas populações). Esses fatores, sozinhos ou em conjunto, podem criar ou exacerbar a vulnerabilidade individual e coletiva ao HIV. (UNAIDS, 2017, p. 26)
\end{abstract}

O objetivo dessa virada narrativa, embora não reflita explicitamente na supressão das consequências narrativas colocadas em marcha pela abordagem extensivista, é apagar os custos impostos por utilizar-se "risco" e por delimitar seus sujeitos. Em suma, a intenção intensivista é desfocar o indivíduo, ou falar diretamente ao indivíduo pertencente àquele "grupo de risco", para alocar vetores do coletivo como política de narratividade, a exemplo dos vetores de gênero, vetores culturais, vetores socioeconômicos, vetores das políticas e de governo e públicas (PASSOS e BARROS, 2009, p. 154). Enfatizando à eficácia do Programa Nacional de DST/Aids, observou-se que a partir da inclusão de práticas narrativas capazes de enfrentar também às epidemias narrativas obteve-se sucesso, que se deve

à reinvenção do modo de dizer, da maneira de formular o problema, da maneira de se comunicar com a população. Foi preciso enfrentar uma política da narratividade presente nas práticas inicias de combate à epidemia ligada ao HIV. Tais práticas expressam, para além do que poder-se-ia mapear como questões epidemiológicas, um certo modo de recortar o socius, um certo modo de produzir subjetividade a partir de critérios marcados pela pertença e identificação a certos (sub) grupos sociais. (PASSOS e BARROS, 2009, p. 153)

A partir da incorporação do conceito de vulnerabilidade é que se pode construir uma cobertura ampla de apoio à contenção epidêmica do HIV. Não se deve reduzir somente às práticas extensivistas, manejadas e comandadas pela força da lei. A ressignificação das narrativas do HIV e da Aids a partir do Estado representou um grande embasamento para as contranarrativas, que utilizaram e reproduziram o conceito de vulnerabilidade ao invés do conceito de grupos de risco. Olhar a saúde e o sujeito individual e coletivo representou construir práticas cidadãs 
de inclusão. Revigorou a concepção de pertencimentos das pessoas que vivem com HIV na sociedade. Desemaranhando as práticas intensivistas, observou-se que

a equipe coordenadora do Programa Nacional apostou num método intensivista que se faz por um movimento para fora da máquina do Estado (BENEVIDES e PASSOS, 2005a; 2005b), incluindo as redes sociais, os direitos dos usuários de drogas ilícitas, a prática da redução de danos e, sobretudo, incluindo as minorias, como os usuários de drogas, profissionais do sexo, transexuais, homossexuais que impõem outras políticas de subjetivação e de narratividade. (PASSOS e BARROS, 2009, p. 153)

Assim, o que se notou nessa transição narrativa de enfrentamento à epidemia de HIV no Brasil respaldou-se na ressignificação de grupo de risco e do conceito de risco para o apoio fundamental no conceito de vulnerabilidade, assim como à possibilitação do protagonismo de suas vidas das pessoas que eram consideradas "grupos de risco" para participar "da cogestão de uma política que por isso mesmo se torna pública" (PASSOS e BARROS, 2009, p. 153). A abordagem extensivista "deixa de ser a meta previamente importante para se tornar um efeito de práticas intensivas em um plano coletivo de forças instituintes (LOURAU, 2004; BELLEGARDE, 2002 apud PASSOS e BARROS, 2009, p. 153). Novamente, analisando os efeitos narrativos causados por duas abordagens em relação ao HIV e à Aids, percebeu que esse sucesso relativo ao programa de prevenção da Aids "se deve ao fato de que a extensão é efeito de um modo de fazer intensivo que aposta nos processos de contágio ou propagação. Eis o modo de fazer intensivista: reverter o sentido negativo do contágio, colocando-o a serviço da vida" (PASSOS e BARROS, 2009, p. 154).

Em uma comparação narrativa sobre as abordagens extensivista e intensivista, Passos e Barros (2009) descrevem duas reflexões sobre a mudança narrativa e política incluída na forma de lidar com a epidemia de HIV. O primeiro ponto se refere

do positivo como índice de morte, para o positivo como afirmação da vida, isto é, do contágio como característica própria de alguém ou de um grupo ao contágio ao contágio como experiência impessoal, coletiva, que orienta uma política pública de DST/AIDS. (PASSOS e BARROS, 2009, p. 155) 
O segundo ponto, já se inserindo como produtor de contranarrativas, ou seja, produtor de ressignificação sobre as narrativas do HIV e da Aids, os autores compreenderam que ocorreu a

\begin{abstract}
a reversão da posição de menoridade para a experimentaçãominoritária, isto é, da identidade de soropositivo e de jovem soropositivo (o doente, o infectado, o acometido) para um protagonismo ativo daquele que, na condição de soropositivo, sai da posição passiva de quem sofre para a atividade de quem se engaja em um processo de mudança de si e do mundo. (PASSOS e BARROS, 2009, p. 155)
\end{abstract}

Desses dois pontos ressaltados pelos autores, percebo que a produção de contranarrativas já se inseria nos efeitos da abordagem intensivista, principalmente porque essa é voltada à contenção dos efeitos "técnicos" causados pela abordagem extensivista. A produção de contranarrativas e a transformação de práticas de cogestão insere uma nova perspectiva sobre o olhar do HIV. Embora edificada essa manifestação intensivista, não se pode acreditar que sua estrutura é sólida o bastante para persistir no tempo e a governos, principalmente às narrativas circuladas e predominantes dos governos que mudam e reformulam as políticas de combate à epidemia de HIV. Mas o que é importante destacar por último da abordagem intensivista, e que será fundamental também para compreender como as contranarrativas são produzidas, considerando seus sujeitos e seus lugares de produção, é notar que a "desestabilização dos eixos dominantes de organização da comunicação nas instituições: o eixo vertical de hierarquização da comunicação entre os diferentes e o eixo horizontal de homogeneização da comunicação entre os iguais" (PASSOS e BARROS, 2009, p. 155). As contranarrativas também se perpetuam em ambientes descentralizados na comunicação, sendo observadas em redes sociais, em rodas de conversa, em torno de personalidades que vivem com HIV, em produções literárias, jornalísticas e audiovisuais que almejam ressignificar as narrativas transnacionais do HIV e da Aids.

\title{
2.3
}

A estruturação de narrativas a partir de figuras de linguagem: metáfora e metonímia como elementos centrais 
Compreendo as metáforas e as metonímias para além do processo de definição único de figuras de linguagem. Elas representam estruturas linguísticas e cognitivas variáveis em tempos e em culturas. Por isso, Punter (2007) argumenta que não existe definição única, universal e concreta na história do que se define como metáfora. As metáforas funcionam em toda parte da linguagem. Para Garcia (2010), a metáfora "é um dos meios mais importantes para a criação de denominações de complexos de representações para os quais não existem ainda designações adequadas" (GARCIA, 2010, p. 106). Além disso, "a existência de similitudes no mundo objetivo, a incapacidade de abstração, a pobreza relativa do vocabulário disponível em contraste com a riqueza e a numerosidade das ideias a transmitir, e ainda, o prazer estético da caracterização pitoresca constituem as motivações da metáfora" (GARCIA, 2010, p. 106). Em suma, Garcia (2010) compreende que as metáforas se expressam na participação de representar a realidade de uma maneira transfigurada (GARCIA, 2010, p. 110-111).

A metonímia é percebida por Littlemore (2015) como uma figura de linguagem e do pensamento em que uma entidade está acostumada a referir-se, ou em termos cognitivos, "fornecer acesso a" outra entidade que está de alguma forma relacionada (LITTLEMORE, 2015, p. 4). Torna-se uma ferramenta usada para pensar sobre as coisas e a usamos para comunicar nossos pensamentos (LITTLEMORE, 2015). Para Garcia (2010) “a metonímia se expressa a partir das relações reais de ordem qualitativa que levam a empregar metonimicamente uma palavra por outra, a designar uma coisa com o nome de outra" (GARCIA, 2010, p. 115). Assim, percebo que as metonímias são elementos fundamentais, independentemente do valor adotado, apresentadas também dentro da construção narrativa do HIV e da Aids.

As metáforas representam uma construção narrativa sobre processos culturais, econômicos, sociais, políticos, linguísticos, presentes dentro da narrativa. Dessa forma, compreender metáforas sobre o HIV e a Aids significa compreender um processo narrativo, construído através do tempo, sobre figurações acerca da infecção e acerca da doença. Sontag (1989), ao mostrar similaridades entre o processo metafórico em torno do HIV e Aids com a Sífilis, reconstrói todo um conjunto narrativo para relacionar as duas representações. A sífilis, compreendida como uma poluição no corpo, estende parte de sua configuração metafórica ao HIV e à Aids, cuja transmissão pode ocorrer por fluídos corporais. A metáfora se 
legitima a partir da construção narrativa de que um vírus, capaz de evoluir a um estado clínico susceptível a doenças oportunistas, detém uma característica de poluir a partir de sua replicação nas células. Punter (2007) entende que a metáfora é talvez o principal sinal de que as palavras não ficam isoladas (PUNTER, 2007, p. 144). Dessa forma, compreender metaforicamente o HIV e Aids a partir da própria construção de "poluição" é reforçar que a metáfora é capaz de construir processos narrativos com palavras distintas.

A partir da compreensão da metáfora como um processo narrativo, compreendo a metonímia como a constituição de elementos importantes dentro desse processo. Punter (2007) associa a metonímia à capacidade de reduzir um elemento a uma única representação (PUNTER, 2007, p. 2). Ao trabalhar com HIV e Aids, a metonímia se faz muito presente à definição de que "HIV" é "Aids". Utiliza-se da metonímia, nesse processo de representação a um único elemento, que o próprio vírus do HIV, mesmo quando controlado por antirretrovirais, resume-se a um estado clínico e social que é a Aids. São dois elementos distintos que não se diferenciam muito na linguagem, embora exerçam diferença significativa na saúde de uma pessoa: o HIV como um vírus controlado pelos antirretrovirais; a Aids como um estado clínico susceptível a infecções oportunistas. A metonímia se forma a partir de um processo cognitivo e linguístico segundo o qual usamos uma coisa para se referenciar a outra (LITTLEMORE, 2015, p. 1). Nesse caso, usa-se a Aids para se referenciar ao HIV. Isso se demonstra porque na metonímia a relação entre um termo e o seu referente é muito mais próxima do que na metáfora (LITTLEMORE, 2015).

Além do carácter referencial da metonímia, utilizar-se de um termo para representar outro, a metonímia se molda a partir da impossibilidade de capturar todos os aspectos da realidade por meio da linguagem (LITTLEMORE, 2015). Isso significa dizer que se emprega a metonímia a partir de símbolos, ou a partir de generalizações amplas, para representar o que queremos dizer, sem se preocupar com todas as especificidades do elemento que se quer representar. Littlemore (2015) exemplifica essa simbologia da metonímia a partir da Torre Eiffel, um símbolo que, para além de um ícone arquitetônico e artístico, representa todo o conjunto de uma Nação: a França. Assim como se utiliza "a França" para representar o povo francês, ações governamentais e estatais. Ou seja, relaciona-se a esse fato a ideia de que pensamos metonimicamente, porque, nas palavras de 
Littlemore (2015), “é fisicamente impossível ativar conscientemente todo o conhecimento que temos de um determinado conceito de uma vez, então tendemos a nos concentrar em um aspecto saliente desse conceito e usar isso como ponto de acesso a todo o conceito"18 (LITTLEMORE, 2015, p. 4-5). Dessa forma, representar HIV como Aids, ou Aids como morte, é focar em um aspecto metonímico de todo o processo narrativo construído para representar o vírus e o estado clínico, ao invés de associar Aids à decorrência da diminuição de células CD4 e à manifestação de infecções oportunistas que podem levar o paciente à morte.

As metáforas e as metonímias se configuram nas narrativas como processos de tradução de uma determinada realidade social (PUNTER, 2007). E, em geral, as traduções podem apresentar falhas significativas. Enfatiza-se ainda que essas figuras de linguagem e figuras de pensamento, pelas quais as narrativas se moldam, não são inocentes. Nesse sentido, existem dois aspectos importantes para compreender como as narrativas se efetivam sobre os sujeitos e os inibem ou os estimulam a agir: os afetos e as emoções.

Reflito constantemente sobre o papel das figuras de linguagem e de pensamento, em especial as metáforas e metonímias, em proporcionar-nos afetos e emoções específicos a partir das narrativas nas apresentadas. Ahmed (2014) sugere que essas figuras de linguagem, as metáforas e as metonímias, são cruciais para a emocionalidade dos textos (AHMED, 2014, p. 12). Dessa forma a emocionalidade de textos, aspecto central desse trabalho, pode ser aferida partir da descrição de como as narrativas nos movem ou como geram efeitos (AHMED, 2014). A partir das narrativas torna-se possível compreender como os elementos afetivos e emotivos se solidificam no estudo da política internacional.

\footnotetext{
${ }^{18}$ Tradução livre. No original: "because it is physically impossible to consciously activate all the knowledge that we have of a particular concept at once, so we tend to focus on a salient aspect of that concept, and use this as point of access to the whole concept."
} 


\section{4 \\ Uma abordagem estética das Relações Internacionais: os afetos e as emoções nas construções narrativas}

A partir da estética como um arcabouço teórico-metodológico na disciplina, Roland Bleiker (2001) insere duas análises interessantes para explicar como abordar as Relações Internacionais: a partir da mimese e a partir da estética. Entretanto, para compreender ambas as abordagens, torna-se necessário compreender antes que toda análise sobre Relações Internacionais, ou sobre qualquer objeto tomado para a pesquisa, é concebida a partir de uma perspectiva. Ou seja, a compreensão de um fenômeno internacional consiste em relatá-lo a partir de elementos já pré-estabelecidos por perspectivas teóricas, a exemplo da análise mimética do realismo, uma das correntes mainstream da disciplina. Implica dizer que o realismo tenta apagar todos os traços de interferência humana, e parte do pressuposto da perfeita semelhança entre significante e significado (BLEIKER, 2001). A abordagem estética, diferente do apagamento do elemento humano e do conjunto de sensibilidade que a representa, recupera esses traços de interferência humana perdidos na análise e na construção do conhecimento. Assim, a compreensão de um fenômeno internacional é feita a partir dos fluxos produtivos entre sensibilidade, razão, memória, imaginação, afetos, emoções que dão "voz e destaque a perspectivas e atores marginalizados nas abordagens dominantes e à natureza e às consequências emocionais dos eventos político-sociais mundiais" (JESUS e TELLEZ, 2014, p. 59).

Baseando-se nas implicações levantadas acerca do papel do estético nas Relações Internacionais e relacionando as perspectivas discursivas com as emoções, é válido questionar "por que estudamos emoções através do discurso?" (KOSCHUT, 2017). Para ilustrar um caminho dessa resposta e dessa contribuição metodológica, Koschut et al (2017) propõe três critérios aos quais o estudo do discurso emocional deve responder, concernente à teoria - o que é emoção? -, à expressão - como as emoções são comunicadas? -, e aos efeitos - o que as emoções fazem? Complemento nessa construção teórica compreender os afetos junto com as emoções, reformulando esse mesmo caminho de Koschut et al (2017) e acrescentando: o que são emoção e afeto? Como as emoções e os afetos são comunicados? E, por fim, o que as emoções e os afetos fazem? 
Ressalto que essas compreensões outras da análise do discurso e de todos os seus efeitos estão inseridos dentro de um "emotional turn" nas disciplinas. Aradau e Huymans (2014) criticam que qualquer novo assunto trazido de fora da disciplina capaz de provocar rebuliços entre seus pesquisadores provoca essa onda de novos "turns". Por constar como uma abordagem recente, a relação do discurso com as emoções e os afetos colocam algumas dificuldades presentes: pouca elaboração dos métodos apropriados e critérios para estudar emoções em discurso (KOSCHUT et al, 2017).

Porém, Koschut et al (2017), junto com outros pesquisadores sobre discursos e emoções, explicam possíveis caminhos para a construção teórico-metodológica das emoções nos discursos. Uma dessas abordagens é compreender como um dos métodos de acessar um elemento empírico do discurso, termos emocionais, conotações, metáforas, assim como comparações e analogias (KOSCHUT et al, 2017). Meu caminho como método é buscar a presença das metáforas e das metonímias nas narrativas (SONTAG, 1984, 1989; AHMED, 2014; BARATA, 2006; TIMERMAN e MAGALHÃES, 2015), que circulam emoções e dos afetos entre interlocutores. Esse tema é relacionado pois

\begin{abstract}
uma característica típica da linguagem afetiva é que ela é altamente figurativa. Figuras de linguagem, em particular metáforas, comparações e analogias, desempenham um papel importante na codificação de expressões emocionais. A metáfora da emoção é um ato simbólico da fala, que deve ilustrar um estado emocional. (KÖVECSES, 2013 apud KOSCHUT et al, 2017)
\end{abstract}

O que a linguagem captura do que é experimentado no corpo é o que se chama emoção, o que não é capturado é o afeto (MASSUMI, 2002). Assim, o afeto atua como uma intensidade "pré-pessoal correspondendo à passagem de um estado experiencial do corpo para outro e implicando um aumento ou diminuição desse corpo de agir" (GILBERT, 2013, p. 145). E a emoção é entendida como "o que experimentamos uma vez que identificamos uma mudança afetiva e a representamos como algo que pode ser nomeado e que pode ser entendido como acontecendo conosco internamente como indivíduos (GILBERT, 2013, p. 145).

Compreendendo os afetos a partir de seus circuitos, uma rede de relações sociais pelas quais a manifestação dos afetos torna-se compreensível, seja a partir da manifestação ou da recepção dos afetos alheios, Safatle (2015) compreende a 
existência da circulação de afetos que nos atraem ou nos repulsam. A partir dos vínculos sociais, dos vínculos pessoais, os afetos tornam-se compreendidos, mas não nomeados. A manifestação das narrativas sobre o HIV e a Aids, dessa forma, constitui-se em um mesmo corpo político pelo qual o circuito dos afetos é manifestado. As sociedades se constituem de afetos específicos e reproduzem a formas hegemônicas de organização da vida "ao produzir continuamente afetos que nos fazem assumir certas possibilidades de vida a despeito de outras" (SAFATLE, 2015, p. 17). As formas de produção da vida, discutidas por Safatle (2015) para falar sobre os efeitos da circulação dos afetos na constituição de subjetividades, fundamentam-se em afetos específicos, ou seja, "elas precisam de tais afetos para continuar a se repetir, a impor seus modos de ordenamento" (SAFATLE, 2015, p. 17). A partir dessa produção de vida, percebe-se outras formas mais singulares, capazes de produzir outros objetos e efeitos a partir da adesão social construída através das afecções (SAFATLE, 2015). Adentrando-se nessa argumentação, as narrativas sobre o HIV e a Aids produzem e fazem circular afetos específicos e delimitados por seus próprios elementos narrativos, a exemplo das metáforas e das metonímias, e produzem, reproduzem, vidas a partir da circulação desses afetos circulados por meio das narrativas. As narrativas são partes constituintes do corpo político e parte fundamental da estruturação da sociedade.

Assim, compreender as sociedades como circuitos de afetos "implicaria partir dos modos de gestão social do medo, partir de sua produção e circulação enquanto estratégia fundamental de aquiescência à norma" (SAFATLE, 2015, p. 18). A implicação de tornar os circuitos de afetos chave central para compreender os efeitos das narrativas sobre o HIV e a Aids, enquanto forças para a produção e modificação de vidas, é vista como estratégica à uma norma intencionada a se prevalecer sobre corpos humanos. Destarte, a inclusão dos $5 \mathrm{H}$ no começo da epidemia do HIV e da Aids como categorias de risco os estigmatizam em relação à norma heterossexual, branca, central e cristã vigente. Pois, a produção de narrativas sobre a infecção pauta-se sobre afetos não-heterossexuais, não-brancos, periféricos e, fundamentalmente, não enquadrados em expectativas cristãs. Enquanto que por um lado, Spinoza (2000) descreveria a manifestação desses afetos como sendo afetos tristes ou afetos felizes, esses estando condicionados ao valor afetivo de aumentar a nossa capacidade de agir, espelhada em aspectos positivos ao sujeito, e aqueles inibindo nós próprios de agirmos, Safatle (2015) coloca que talvez não 
exista paixões tristes ou paixões afirmativas - descrevendo qualitativamente a manifestação afetiva - "existem paixões, com sua capacidade de às vezes nos fazer tristes, às vezes felizes" (SAFATLE, 2015, p. 22).

A capacidade das narrativas sobre o HIV e a Aids de mover as paixões nesse circuito de afetos reforça a compreensão de que os afetos são elementos importantes na política, pois qualquer circulação de afetos em tons inibidores sobre nossa capacidade de agir paralisa e desacelera o corpo político. Ressalta-se ainda que "não há política sem corpo, dizem, cada um à sua maneira, Rousseau, Hobbes, Spinoza, e não deveríamos esquecer de tal premissa (SAFATLE, 2015, p. 21)”. O corpo, dessa forma, não é apenas “o espaço no qual as afecções são produzidas, ele também é produto de afecções. As afecções constroem o corpo em suas regiões de intensidade, em sua responsividade" (SAFATLE, 2015, p. 22). Assim, o corpo não só produz afecções como as afecções também constroem o corpo. As narrativas não apenas constroem o corpo político e social e uma representação do sujeito, mas também o sujeito constrói narrativas e representações de si próprio, a partir dos elementos narrativos e afetivos que circulam no corpo político e social.

Nas relações entre o sujeito e o corpo social, Safatle (2015) representa as metáforas como circulantes ao circuito de afetos e cuja natureza deriva do regime de afecções que sustentam a adesão social, ou seja, as metáforas aglutinam a representação de indivíduos no corpo social (SAFATLE, 2015, p. 22). Entretanto, é valido ressaltar que o processo inverso, de desaglutinação dos indivíduos no corpo social, impulsionando a representação de que eles não são bem-vindos ou pertencentes à norma social, também se vincula à representação metafórica. Nas narrativas sobre o HIV e a Aids, torna-se perceptível a caracterização pitoresca dos sujeitos com HIV e Aids e como eles, a partir dos elementos narrativos metafóricos e metonímicos, tornam-se sujeitos perecíveis na sociedade e descartados (SONTAG, 1989; BARATA, 2006).

Compreendendo os afetos como circulantes no corpo social e político, Simondon (2005) discorre que nossas capacidades individuais de ação são dependentes de nossas relações com os outros, que constituem nossa agência e subjetividade e que nem sempre podem ser representadas de forma consciente (SIMONDON, 2005 apud GILBERT, 2013, p. 144). O espaço onde essas relações ocorrem estão no nível de emoção e de afeto. Pela capacidade de os afetos circularem no corpo político a partir das narrativas, seus efeitos impactam os 
sujeitos. Abalar a capacidade de agir conecta-se à compreensão de Massumi (2002) sobre a descrição do afeto, que o escreve como uma intensidade pré-pessoal correspondente à passagem de um estado experiencial do corpo para outro e implicando em um aumento ou diminuição da capacidade desse corpo de agir, complementando ainda "o corpo" em seu sentido mais amplo possível, incluindo “corpos mentais ou ideais" (MASSUMI, 2002; GILBERT, 2013). A dimensão afetiva é "uma extensão de corpos que estão constantemente se influenciando e que, por isso Simondon insiste, essas relações de influência mútua são frequentemente constitutivas de suas capacidades de agir de maneira geral" (GILBERT, 2013, p. 146). Embora eu perceba o uso contínuo de "afeto" - e de outras classes de palavras referentes ao "afeto", como afetuoso, afetivo, afetar, entre outras - não se enquadra, exclusivamente, o uso de "afeto" como característicos de forças positivas. Afetos são vistos também como antagonistas a qualquer manifestação positiva ou feliz. Assim como Spinoza (2000) os adequa como felizes e tristes e Safatle (2015) os compreende como paixões que ora nos deixam tristes, ora nos deixam felizes, de um modo geral, a capacidade de sermos afetados por essas experiências subjetivas não nomeáveis não deve ser conectada ao que o significado da palavra nos remete em nosso vocabulário. Em suma, devemos sempre nos recordar que possuímos corpos e somos constantemente influenciados por intensidades e ressonâncias afetivas distintas, capazes de nos influenciar ou nos condicionar em nossas políticas e em outras crenças (RUTH, 2011, p. 436).

Porém, como conseguimos sentir ou até mesmo identificar nossos afetos? É importante destacar, embora não seja o ponto principal dessa dissertação, uma discussão acerca da neurociência na compreensão dos afetos (RUTH, 2011; GILBERT, 2013). Essa particular "virada" da neurociência para estudar afetos e emoções tomou lugar recentemente nas ciências humanas e sociais (RUTH, 2011, p. 434). Além de compreender e discutir como a nossa formação neurológica capta e identifica os afetos dentro do seio social, além de discutir como somos vetores de afetos a outrem, há um considerável campo a ser explorado acerca das relações culturais do sistema endocrinológico em relação aos afetos (GILBERT, 2013, p. 151). As relações olfativas - a produção, a tradução, a formação - de afetos de outros sobre nós, e nós sobre os outros, é um importante caminho a ser considerado, pois os nossos cheiros e o cheiros do mundo e de seus sujeitos exercem influência fundamental em nossa própria relação com os outros e com o mundo (GILBERT, 
2013, p. 150-151). Em partes, percebo que nossos próprios sentidos - atendidos aqui como olfato, paladar, visão, tato e audição - são nossa principal conexão com o mundo e são importantes produtores, tradutores e formadores de nossos afetos (RUTH, 2011; GILBERT, 2013; BRETON, 2016).

Nessa discussão sobre os receptores afetivos, Massumi (2002) discute que a partir da superfície dos corpos, nesse contato de interface com as coisas, a intensidade é incorporada em reações puramente autônomas mais diretamente manifestadas na pele (MASSUMI, 2002, p. 25). Discutir a recepção a partir da pele, do contato, como um canal de recepção e manifestação desses afetos permite introduzir pontos afetivos importantes sobre a concepção do outro. A partir dessa relação de recepção, somos capazes, mas talvez não plenamente, de nomear as intensidades sentidas e qualificá-las. A qualificação de nossos afetos, vislumbrados também como a nossa tentativa em nos entender e nos traduzir, adentra-se ao campo das emoções. Se sentimos e dizemos: "que triste estou; que feliz estou; que estressado estou", traduzimos nossos afetos em palavras e nomeamos as emoções. E quando não nomeamos, mas percebemos intensidades distintas sobre nós, compreendemos os afetos como implicados a ressoar, interferir, amplificar ou amortecer nossos corpos, nossas capacidades de agir a partir de um encontro (MASSUMI, 2002, p. 25). O encontro é sobre encontrar alguém, um objeto, um fato, um evento, uma inquietude, um "perceber-se diante de algo", tendo esse algo inúmeros sinônimos. E desse encontro, podemos nos aproximar ou nos afastar (AHMED, 2014).

Na tradução de nossos encontros, perdemos muito dessa tradução ao encaixar os afetos em estruturas linguísticas simbólicas (MASSUMI, 2002). Ao classificarmos nossos afetos como "isso me deixa triste", referindo-se à qualificação do nosso encontro com algo, parte dos afetos não compreendidos como tristes, pertencentes até mesmo de outras traduções dentro das emoções, acaba se perdendo na tradução. Nas narrativas, a ênfase em tocar o outro a partir das palavras permite, a partir das metáforas e das metonímias, não entregar propriamente ao receptor dessa narrativa os elementos afetivos traduzidos como emoções. As narrativas possuem a dimensão de manifestar, por seus elementos de linguagem e de pensamento, afetos diversos em nós mesmos, sem necessariamente guiar-nos por emoções traduzidas e compreender, desde cedo, uma narrativa como triste, feliz, estressante, mirabolante, encantadora. 
As economias afetivas também são vistas como imprescindíveis nesse processo de circulação de afetos, porque as emoções também são circulantes nesses circuitos. A própria dinamicidade do conceito de economias por Ahmed (2014) já insere e concretiza a perspectiva de que na sociedade os afetos e as emoções circulam entre os corpos individuais e coletivos, impregna-os de narrativas, redesenha o espaço de inclusão e exclusão. Apreendendo da crítica marxista da lógica do capital, Ahmed (2014) vai construir a compreensão de economias afetivas para sugerir que os objetos de emoções são circulantes e distribuídos por um campo social e psíquico (AHMED, 2014, p. 45). Em diálogo com Safatle (2015) sobre os circuitos afetivos, Ahmed (2014) também contribui dizendo que “o afeto não reside positivamente no signo ou mercadoria, mas é produzido como um efeito de sua circulação"19 (AHMED, 2014, p. 45). O fato de circularem - os afetos e as emoções - na sociedade e produzirem efeitos afetivos e emocionais nos corpos representa as economias afetivas. A ideia principal das economias afetivas é que os afetos e as emoções não residem particularmente em um objeto ou em um signo, elas são circulantes entre os objetos, os signos e os corpos. Por compreender a circulação de afetos e emoções, podemos também visualizar como o processo de ressignificação das narrativas do HIV e da Aids depende da circulação desses afetos e dessas emoções presentes nessas narrativas, a fim que novos afetos e novas emoções tomem o espaço e contribuam com a ressignificação da epidemia narrativa do HIV.

Quando abordo que as narrativas do HIV e da Aids constituem economias afetivas, eu me refiro à essa compreensão de Ahmed (2014), principalmente porque as narrativas circulam afetos e emoções nos signos e nos corpos, como também entre signos e corpos, ou seja, entre os elementos constituídos das narrativas e entre os corpos individuais e coletivos. As narrativas sobre o HIV a Aids moldam as superfícies dos corpos individuais e coletivos, criando orientações em relação aos outros: afastar-se ou aproximar-se (AHMED, 2014). Essas orientações se originam a partir de nossas interpretações afetivas, de nossas traduções emocionais. Assim, ao conhecermos o mundo a partir de nossos sentidos (BRETON, 2016), e senti-lo vivamente, compreendemos como nossos afetos e nossas emoções nos movem em relação a pessoas e a objetos sempre a partir de duas orientações afastar-se ou aproximar-se (AHMED, 2014). Insiro ainda que as emoções são capazes,

\footnotetext{
${ }^{19}$ Tradução livre. No original: "affect does not reside positively in the sign or commodity, but is produced as an effect of its circulation".
} 
juntamente com os afetos, de criar o efeito das superfícies e das fronteiras, possibilitando moldar os corpos e distingui-los em moldes diferentes, além de distinguir os de dentro dos de fora (AHMED, 2014). Somos moldados a partir do contato com o outro e somos movidos pelas emoções. As narrativas, especificando aquelas sobre o HIV e a Aids, descrevem e moldam as superfícies dos corpos individuais e coletivos, assim como influenciam na narrativa dos sujeitos, dos objetos e das palavras (AHMED, 2014). A partir da reação afetiva e emotiva dos perpetradores discursivos, conseguimos compreender quais são seus efeitos: se a partir desse contato nós nos aproximamos ou nos afastamos dos sujeitos, dos objetos e das palavras.

Grande parte da construção das narrativas sobre os outros é, justamente, ressaltar que a existência do outro não é "a nossa existência". Essa relação eu e outro, compreendida por Ahmed (2014) a partir da existência de imigrantes e refugiados em busca de asilo, implica que as narrativas funcionam por meio da alteridade (AHMED, 2014, p. 1). Aplicando-se ainda a ideia do imigrante ou do refugiado, Ahmed (2014) aponta um caráter central sobre a intencionalidade narrativa, que convida o leitor a adotar uma posição dentro da narrativa, em posições mais nacionalistas, a posição convocada pela narração é guiar os afetos e as emoções por meio do desenvolvimento de "certa raiva contra esses outros ilegítimos, que são representados como 'enxames' na nação" (AHMED, 2014, p. 1). Outra posição discutida a partir das emoções sobre a intencionalidade narrativa é sentir-se "ferido" pelos outros, que estão "pegando o que é seu” (AHMED, 2014).

Concernente ao HIV e à Aids, as narrativas orientam os afetos e as emoções a afastar-se da infecção, a tê-la como o vírus alheio, a encaixá-la como não pertencente aos sujeitos fora dos grupos ditos de "risco", a compreendê-la como inexistente para os heterossexuais e incondizente com a realidade, mesmo que, pelo lado da saúde e da ciência, os dados revelem a maior taxa de contágio entre os heterossexuais, entre aqueles excluídos das narrativas sobre o HIV e a Aids (SONTAG, 1989; BARATA, 2006). Dados apontam que de 2007 a 2019, os heterossexuais foram responsáveis por $58 \%$ dos novos casos de infecção por HIV (CIMINO, 2020).

Existe uma conexão entre os afetos e as emoções na linguagem metafórica e metonímica. As metáforas nos mostram como as emoções se constituem como atributos do coletivo. A partir das narrativas, percebe-se através desse recurso 
linguístico a manipulação e a descrição de sentimentos que deveriam manifestar-se nos sujeitos ouvintes (AHMED, 2014, p. 2). Dessa forma, Ahmed (2014) não pensa sobre a emocionalidade como característica de corpos, sejam individuais ou coletivos, a emocionalidade é compreendida como responsável por moldar as superfícies dos corpos através da repetição de ações pelo tempo, incluindo orientações no direcionamento a outros e no afastamento de outros (AHMED, 2014, p. 4).

Parto para a mobilização da literatura de afetos e emoções para recuperar, como pregado pela abordagem estética das Relações Internacionais, os traçados humanos perdidos em seu caminho quando a análise mimese se torna mais presente (BLEIKER, 2001). Desses traços e traçados, eu coloco a compreensão das emoções pelas superfícies corpóreas ou não como parte dos traços humanos perdidos nas análises em Relações Internacionais. Deixou-se de fora talvez a única potência que movesse os humanos na sua relação com o mundo, deixou-se de fora elementos fundamentais na constituição estética, na constituição dos próprios humanos, deixou-se de fora todo o sentir e os efeitos de constituir-se de carnes e ossos e sofrer por nossa própria descoberta e captura com o mundo (AHMED, 2014; BRETON, 2016).

Mas as emoções não partem apenas de nossas traduções. A língua cotidiana das emoções está baseada nas presunções da interioridade (AHMED, 2014, p. 8). Ahmed (2014) ainda se junta a ideia de sociólogos e antropólogos, cuja argumentação implica que as emoções não deveriam ser entendidas como estados psicológicos, senão como práticas sociais e culturais. Sempre recuperando nossa inserção no mundo, é importante colocar que "as emoções não são simplesmente sensações que 'eu' ou 'nós' temos, senão é através das emoções que nós respondemos aos objetos e aos outros, que as superfícies ou as bordas são feitas: o ‘eu' e o ‘nós' são moldados pelo contato com outros"20 (AHMED, 2014, p. 10).

\footnotetext{
${ }^{20}$ Tradução livre. No original: "So emotions are not simply something 'I' or 'we' have. Rather, it is through emotions, or how we respond to objects and others, that surfaces or boundaries are made: the 'I' and the 'we' are shaped by, and even take the shape of, contact with others'.
} 


\section{5}

\section{Conclusão}

Um dos pontos fundamentais abordados nesse primeiro capítulo foi compreender as metodologias possíveis para a pesquisa acadêmica em Relações Internacionais. A autobiografia, a autoetnografia e as narrativas se mostraram como instrumentos viáveis para explicar realidades transnacionais, sem excluir perspectivas que enfatizam os traços e traçados humanos dessas análises. É necessário enfatizar que se trata de metodologias possíveis, reforçando o caráter de possibilidades outras na academia, sem impor nenhuma perspectiva sobre as demais. A construção acadêmica é composta por olhares múltiplos e essa multiplicidade enriquece a academia e o diálogo científico.

A compreensão das abordagens extensivistas e intensivistas também auxilia na edificação da pesquisa, representando como escolhas adotadas pelo Estado para manejar uma epidemia impactaram na própria produção da narrativa epidêmica. Tanto as abordagens extensivistas quanto as intensivistas representaram pontos construtores ao narrar o HIV e a Aids. Nem sempre essas narrativas se direcionaram à liberdade e ao acolhimento dos sujeitos, como foi o caso das ações extensivistas. Tentando reverter as consequências políticas dessas narrativas, expandiu-se a abordagem intensivista. Houve um constante processo de narrar e contranarrar a epidemia.

Nas narrativas encontramos figuras de linguagem, metáforas e metonímias, que ditam como a realidade é construída. A realidade do HIV e da Aids se pautou nessa construção narrativa, que será explorada a partir do próximo capítulo. Além disso, percebemos como os afetos e as emoções são manifestados a partir da linguagem, seja ela traduzida ou não. Os afetos e as emoções também constituem outro tópico fundamental na estrutura de minha pesquisa, além de estarem conectados às narrativas do HIV e da Aids.

Por fim, ressalto que a junção dos elementos metodológicos esboçados aqui, juntamente as estruturas das narrativas e os afetos e emoções como forças atreladas ao ato de narrar, serão desdobradas nos próximos capítulos. Em especial, o capítulo dois buscará retomar e adentrar nas narrativas do HIV e da Aids e entender quais afetos e emoções são manifestadas sobre o sujeito coletivo e individual. 


\section{As narrativas do HIV e da Aids: a construção narrativa de uma epidemia}

\section{1}

\section{Introdução}

A caracterização do HIV e da Aids não é um fenômeno exclusivo do ano que escrevo, 2020 e 2021, principalmente porque as narrativas circulam afetos e emoções na sociedade juntamente com o aparecimento da Aids e do HIV nas décadas de 1980 e 1990. Nessas décadas, a infecção desdobrava-se em caminhos enigmáticos, misteriosos, poucos acessíveis aos cientistas em um primeiro momento. Trataram-na como DIRG, Doença Imunológica Relacionada aos Gays. O processo de conhecimento da infecção ocorreu paulatinamente, a cada nova descoberta do HIV em pessoas não pertencentes à comunidade gay, foi-se incorporando ao conhecimento dos cientistas e médicos novas características de infecção do vírus. Destarte, incorporava-se também essas pessoas a novos grupos susceptíveis à infecção, renomeando, dessa forma, quem era atingido pelo vírus. Mas esse quadro epidemiológico, traçado principalmente pela inclusão dos homossexuais na relação com o HIV e a Aids, embora representasse uma incógnita a princípio, não foi isento de representações metafóricas e metonímicas. Além disso, conforme os novos grupos suscetíveis à infecção eram desenhados pela ciência e pela mídia, as narrativas do HIV e da Aids também os incorporava representando-os no mundo social.

Mesmo sem determinar cientificamente os caminhos pelos quais o vírus do HIV percorre para deixar o corpo aberto às infecções oportunistas, reinterpretandoo como um corpo com Aids e construindo-o como uma impressão também social, o HIV e a Aids se apropriaram de narrativas sobre a doença já existentes nos circuitos sociais de afetos. Como argumentarei, Susan Sontag (1984) ilustra as metáforas sobre a doença presentes na sociedade, que mesclam narrativas desde a época da Peste Bubônica até a persistente construção narrativa sobre os Cânceres. Sontag (1984) mostra como determinados corpos humanos não ficaram imunes às 
narrativas de exclusão desses corpos, considerados impuros, do resto da sociedade, considerada pura. A ideia de poluição presente na narrativa sobre a doença, em contraste com a ideia de pureza, em especial em relação à Sífilis, e retomada pelo HIV e pela Aids, torna-se uma das primeiras fronteiras marcadas sobre esses corpos, como compreende Ahmed (2014), reinserindo-os na sociedade a partir de novas emoções e novos afetos, que sempre estiveram presentes, mas que pouco eram notados pelos corpos isentos das narrativas sobre a infecção.

A partir dessa reflexão, divido esse capítulo em duas seções. Na primeira seção, eu buscarei discutir a doença como metáfora e compreender como as narrativas do HIV e da Aids se moldaram no início da epidemia. As primeiras interpretações sobre o HIV e a Aids e a utilização de figuras de linguagem para elucidar a relação entre a infecção e a sociedade serão importantes para compreender as consequências e reinterpretações dessas narrativas décadas depois. O papel da mídia foi central nesse processo de escalonamento de narrativas sobre o HIV e a Aids a partir dos primeiros casos da infecção. Compreender esses traços constituídos no passado nos permitirá adentrar à próxima seção. Na segunda parte desse capítulo, pretendo trazer à discussão outras faces das narrativas do HIV e da Aids que são complementares às narrativas dominantes. Elucidar questões temporais, sobre o futuro das pessoas vivendo com HIV no início da epidemia, além de compreender como discernimentos morais estão associados às narrativas, permite desdobrar-nos sobre as complexidades das narrações e do HIV e da Aids. Além disso, trago desdobramentos das narrativas em rumores, e brevemente discuto as fronteiras da infecção e seus desafios.

\section{2}

\section{A doença e o HIV e a Aids como metáforas: narrativas de exclusão sobre corpos infectados}

A expressão da doença como metáfora, a partir da obtenção de uma cidadania, talvez seja um dos pontos mais marcantes de Sontag (1984) para revelar a dimensão dos efeitos narrativos sobre os corpos. Nós possuímos um passaporte, e ele permite nos colocar em dois reinos: o reino da saúde e/ou o reino da doença. Com o passaporte carimbado, estamos no reino da doença e enfrentamos toda a diferença 
que estar nesse reino significa. Esse é um reino abarcante de pensamentos metafóricos, constituintes de uma prisão em torno da doença, uma condenação. Em descrição sobre o câncer, Sontag (1984) revela um afastamento existente entre os familiares da pessoa com câncer, algo moralmente contagioso. O câncer é visto como uma maldição, como um destruidor invencível. Superar parte dessas metáforas não se direciona em sonegar a verdade ao paciente, mas em retificar a concepção da doença por meio de sua desmistificação. Conecta à possibilidade de o câncer ser um escândalo, que coloca em perigo a vida, os sentimentos, uma perda, de promoção ou de emprego, um momento de segredos quando os pacientes se tornam mais reservados em relação à doença. $\mathrm{O}$ câncer, nessa época descrita por Sontag (1984), carregava consigo essas metáforas da deterioração humana, uma deterioração celular lenta, e representava aspectos imaginativos e reais de pacientes frágeis. Era tratado como algo vergonhoso, "porque é considerado obsceno, no sentido original da palavra: de mau presságio, abominável, repugnante aos sentidos" (SONTAG, 1984, p. 7).

As metáforas ligadas ao câncer são de natureza particularmente horrível, segundo Sontag (1984), ao contrário das doenças cardíacas: não existe vergonha sobre um ataque cardíaco, nem mesmo se esconde da família as condições impostas pelo coração. Em metáforas topográficas, diz-se que o câncer se espalha, se prolifera, se difunde (SONTAG, 1984). Nos casos de tuberculosos, envolvem-se metáforas como uma doença da pobreza, da privação e da paixão, principalmente associada a grandes escritores que morreram de tuberculose. Associa-se o câncer a uma doença punitiva: “por que eu?", tendo como sentido a expressão de uma doença punitiva, que seleciona indivíduos e os corrói. Ao contrário do ataque cardíaco descrito anteriormente, o paciente cardíaco pouco enxerga em seu abatimento um castigo corrosivo, nem se questiona muito o motivo desse ataque. São processos metafóricos diferentes. O câncer representa um longo processo de sofrimento, metaforizado em corrosão, enquanto o ataque cardíaco é um acontecimento rápido, sem tempo para reflexão e indagação para além da dor sentida naquele instante. Por conceber o câncer como doença punitiva, percebe-se, enfim, um caráter de luta, ou até mesmo de cruzada - daquelas religiosas - para enfrentar a doença do câncer. Vitimiza-se seu paciente: a pessoa foi "vítima" de câncer. Também a glorifica: a pessoa "venceu uma batalha". Sontag (1984) enfatiza uma contínua necessidade de todos ao redor da pessoa com câncer - ou com tuberculose, ou com HIV, ou com 
qualquer doença metaforizada - evitam falar constantemente o nome da doença insinuando-a como a síntese do mal.

A doença como metáfora se constrói como processo narrativo de enfermidades não apenas a partir da compreensão metafórica, mas também a partir da ênfase metonímica dessas doenças. Toma-se a palavra "câncer", pelo menos a partir da obra de Sontag (1984), como conectado a metonímias sobre a deterioração da vida pela morte, pelo sofrimento, pela dor e pelo medo. Essas emoções e esses afetos circulam em torno do paciente e de sua comunidade afetiva. Por um instante, quiçá até o fim da enfermidade, o câncer será visto como uma doença viva no espaço corporal. A partir disso, constroem-se também mitologias em torno das doenças. Enquanto a tuberculose era ilustrada como como a doença da paixão, e o desenvolvimento sintomático a partir da febre visualizada como ardência interior (SONTAG, 1984, p. 15), o câncer é construído a partir da mitologia da repressão, a partir da insuficiência de paixão (SONTAG, 1984, p. 16). Pelas Artes e pelas literaturas, percebeu-se que as emoções eram as causadoras de doenças, e essa construção narrativa sobreviveu em grande parte do século XX, até achar a cura (SONTAG, 1984, p. 35).

As narrativas sobre a tuberculose construíram-se diferentes das narrativas do câncer e das narrativas do HIV e da Aids. A expressão romântica, inclusive influente na literatura brasileira durante a segunda fase do Romantismo, permeou as narrativas sobre a tuberculose. Enquanto grandes epidemias do passado, a exemplo da peste bubônica, tifo, cólera, atacavam cada pessoa como membro de uma comunidade atingida, a tuberculose desvirtuava-se dessa relação, obrigando a pessoa doente a se isolar de sua comunidade (SONTAG, 1984). A tuberculose, por mais incidente na sua população, também se constituiu ao redor de mistérios aos indivíduos, mas sendo apreendida como uma flecha mortífera capaz de atingir qualquer um e, em suma, personalizando suas vítimas uma a uma (SONTAG, 1984, p. 27). Por suposto, a personalização das pessoas infectadas tornou-se frequente quando essas pessoas representavam personalidades públicas. O câncer continua personalizando as pessoas, principalmente quando elas se conectavam à vida pública. A personalização das pessoas infectadas pelo HIV, principalmente a partir da ênfase midiática, foi fundamental para mostrar à população sobre a possibilidade de qualquer um adquirir o vírus (BARATA, 2006). Em tempos pandêmicos, a mídia constantemente personaliza as pessoas com COVID-19, principalmente quando as 
pessoas falecem em decorrência do vírus, seja a partir de pessoas públicas - para mostrar a truculência do vírus sobre a fragilidade humana -, seja a partir das outras pessoas - para humanizar e personalizar a vida humana e fugir dos números escandalosos. Como todas as narrativas, a personalização das "vítimas", como descrito por Sontag (1984), ilustra os sujeitos dessas histórias, seus dramas, suas emoções, seus afetos, suas deteriorações diante das epidemias e das pandemias.

A construção das narrativas sobre o câncer pautava-se na personificação da dor, a pessoa com câncer e que sofre dessa enfermidade (SONTAG, 1984). A dor, como emoção, molda-se também com o contato com os outros, não mais sendo associada e descrita como uma experiência privada, muitas vezes solitária, como um sentimento pertencente somente a alguém, excluindo os outros de senti-la (AHMED, 2014, p. 20). Os afetos circulam na comunidade ao redor da pessoa com câncer, e desses afetos destaca-se a dor sentida em comunidade. As metáforas construídas e as narrativas empregadas são compartilhadas por todos (SONTAG, 1984; AHMED, 2014). Ahmed figura a dor como frequentemente apresentada como sentimento isolado no ocidente (AHMED, 2014, p. 28-29). Pelo isolamento da dor, constrói-se a impossibilidade de habitar o corpo do outro criando um desejo de saber "como é isso", pois "ninguém pode saber o que é ter a minha dor, mesmo querendo que os outros reconheçam o que eu sinto"21 (AHMED, 2014, p. 29). O desejo de compartilhar a dor, de sentir a dor do outro através de meu corpo, é muitas vezes compreendido pela construção do amor: "eu quero ter sua dor para que possa se livrar dela, para que não tenha que sentir"22 (AHMED, 2014, p. 30). Assim, a sociabilidade da dor, como representou Ahmed (2014), pode permear e adentrar-se nos circuitos afetivos daqueles que estão envolvidos mais intimamente com a doença.

A dor também se associa às noções punitivas da doença, a exemplo da discussão sobre as construções narrativas sobre o câncer. Associa-se a uma luta ou à cruzada contra o câncer, a uma batalha a ser enfrentada com muito sofrimento, com muita dor, pois se compreende, por meios de suas narrativas, que o câncer é o vilão e se configura como uma doença assassina (SONTAG, 1984, p. 38). Nessa

\footnotetext{
${ }^{21}$ Tradução livre. No original: "It is because no one can know what it feels like to have my pain that I want loved others to acknowledge how I feel”.

22 Tradução livre. No original: "I want to have her pain so she can be released from it, so she doesn't have to feel it'".
} 
narrativa, as pessoas com câncer são vítimas, "a doença é o réu, mas ao doente também cabe culpa. Teorias psicológicas da doença amplamente difundidas atribuem ao infeliz canceroso tanto a responsabilidade de ter caído enfermo quanto a de curar-se" (SONTAG, 1984, p. 38).

Apreender as doenças como metáforas é compreender seu uso para reforçar ou acusar uma sociedade de ser injusta ou corrupta (SONTAG, 1984, p. 46). Ao questionarmos sobre as narrativas das doenças e visualizarmos os elementos narrativos, tanto as metáforas quanto as metonímias, podemos invocar interpretações punitivas sobre os corpos humanos. Sontag (1984) relembra que "tanto a tuberculose como o câncer foram regularmente invocados para condenar práticas e ideais repressivos, sendo a repressão concebida como uma situação que priva as pessoas de força (tuberculose) ou de flexibilidade e espontaneidade (câncer)" (SONTAG, 1984, p. 48).

Assim como adotado por Passos e Barros (2009), acerca da política de narratividade da saúde, mencionando as tratativas em torno do HIV e da Aids, Sontag (1989) reflete, mais tarde, sobre a doença e as metáforas, embora, diferente de enfatizar o câncer, a partir da própria construção autobiográfica, retome esse movimento a partir da epidemia de HIV. Em uma de suas observações, assemelhando-se da política de narratividade, Sontag (1989) relata que "a metáfora mais generalizada sobrevive nas campanhas de saúde pública, que rotineiramente apresentam a doença como algo que invade a sociedade, e as tentativas de reduzir a mortalidade causada por uma determinada doença são chamadas de lutas e guerras" (SONTAG, 1989, p. 45). Uma batalha travada por todos nós, sem recursos e ferramentas medievais, sem enfrentamentos corpo a corpo, a sistematização da doença como uma guerra a ser enfrentada reflete na conscientização coletiva do papel individual no enfrentamento de pandemias, seja a partir do papel do Estado na maneira de enfrentar as infecções (PASSOS e BARROS, 2009), seja a partir da experiência humana, dos circuitos afetivos ao nosso redor, no compartilhamento de emoções daqueles que encontraram a doença em suas comunidades afetivas (AHMED, 2014; SAFATLE, 2015).

Porém, assume-se uma vantagem em construir metáforas militares - uma batalha ou guerra a vencer, a construção do inimigo a partir da invisibilidade de seu propagador e da visibilidade de seus efeitos. A partir da narrativa militar, a projeção de apelos por mais empenho e mais gastos na área da pesquisa, como "uma 
emergência na qual nenhum sacrifício é considerado excessivo" (SONTAG, 1989, p. 46), o Estado articula-se no enfrentamento dessas novas ameaças. As metáforas, mesmo constituindo processos narrativos temidos, fornecem possibilidades orçamentárias e científicas para o enfrentamento desse inimigo. Porém, como se percebeu em Passos e Barros (2009), as metáforas também se constroem a partir desse enfrentamento, a partir da delimitação dos grupos de riscos, provocando um movimento já explicado, por suposto através de metáforas, por Sontag (1989). O enfrentamento da doença, das infecções como um todo, dá forma à visão de uma doença particularmente temida como um "outro" alienígena, e se for narrada como um inimigo a ser vencido, essas metáforas encaminham, por mais cruel que essa narrativa possa representar, "a culpa sobre o paciente, muito embora ele continue sendo encarado como vítima" (SONTAG, 1989, p. 46). Assim, o movimento de narrativas para a prevenção do HIV e da Aids, visto em Passos e Barros (2009) a partir do movimento extensivista da abordagem da infecção, permitindo a delimitação dos "grupos de riscos", gerou narrativas sobre os culpados dessa infecção.

Vislumbrando o HIV e a Aids a partir de uma narrativa enigmática, cujas origens tornam-se misteriosas, assim como a atuação do vírus nos corpos humanos, Mirko Grmek (1995), historiador franco-croata da medicina, escritor e cientista, considerado um dos pioneiros e fundadores da história da medicina (REGINA, 2013), explica as faces sociológicas de sua interpretação sobre a expansão do HIV e da Aids no mundo, principalmente nos Estados Unidos, um dos primeiros epicentros no norte global, relembrando a si mesmo que sua explicação "nada tem de particularmente original" (GRMEK, 1995, p. 233). Em suas palavras e em sua forma narrativa de explicar a emergência do HIV e da Aids, Grmek (1995) narra que

a emergência da epidemia atual está ligada a algumas mudanças sociais que caracterizam a segunda metade do século XX: o caldeamento das populações, um novo tipo de relacionamento sexual (liberalização dos costumes, promiscuidade homossexual organizada), o uso maciço das drogas intravenosas, os progressos da transfusão de sangue etc. (GRMEK, 1995, p. 233).

Para além disso, Grmek (1995) reforça a existência de uma "promiscuidade homossexual" entre homens para reforçar quem seriam alguns dos "culpados" pela 
epidemia de HIV, narrando que "a promiscuidade homossexual, organizada em ampla rede internacional, tem funcionado como um verdadeiro caldo de cultura para o vírus da Aids. A novidade histórica não estava, evidentemente, na homossexualidade em si, mas na amplitude e no grau da promiscuidade" (GRMEK, 1995, p. 235). A construção narrativa do HIV e da Aids, tendo Grmek (1995) como um de seus colabores, reitera que as narrativas sobre o HIV e a Aids abarcam também narrativas já existentes sobre os homossexuais, mas, nesse caso descrito por Grmek (1995), essas narrativas aportam uma nova característica: a culpabilidade de seus corpos e de suas práticas na poluição da sociedade. Essas narrativas, como mencionado anteriormente acerca do não ineditismo, guiam parte do pensamento social e científico para relembrar que se não fossem as mudanças dos costumes mantidos até aquele período, o impacto da Aids na sociedade não seria tão amplo como entendido pelo autor (GRMEK, 1995, p. 236).

Robert Gallo, considerado, mais tarde, um dos descobridores do vírus do HIV, reforçava o discurso de que a "transmissão da doença poderia ser exclusivamente por via anal, reforçando a construção da Aids como doença de homossexuais, e simplesmente fechando os olhos para a possibilidade de os heterossexuais também praticarem sexo anal” (BARATA, 2006, p. 40). E foi necessário apenas os primeiros anos das manifestações clínicas do HIV e da Aids na sociedade para concretizar as narrativas da infecção sobre corpos homossexuais a princípio. Segundo os dados do Ministério da Saúde do Brasil, "aponta-se que, entre os anos 1980 e 1998, ocorreu uma nítida inversão no quadro de transmissão da Aids, que, se até 1992 atingia majoritariamente os homossexuais; a partir deste período, passou a infectar a população heterossexual com maior intensidade" (BARATA, 2006, p. 40). Existem metáforas sobre o HIV e a Aids que abrangem a população heterossexual, mas nenhuma delas se justificou, ou se justifica, por suas práticas sexuais adotadas. Porém, é curioso notar que, como será visto mais para frente, as narrativas sobre os heterossexuais se constroem principalmente sobre as mulheres que vivem com HIV e dão à luz e acabam transmitindo o HIV para a criança através da transmissão vertical durante o parto. A mulher é vista como vítima quando o marido se infecta em outras práticas e é vista como culpada se durante o parto a criança é exposta ao vírus.

Dessa forma, Sontag (1989) compreende que o câncer deixou de ser a doença mais temida de todas, perdendo grande parte de seu estigma devido ao "surgimento 
de uma doença cuja capacidade de estigmatizar, de gerar identidades deterioradas, é muito maior" (SONTAG, 1989, p. 46). Como Grmek (1995) mostrou, a deterioração das identidades e de associações simples, como processos metonímicos - de ligar a compreensão de "A" pela existência de "B", em outras palavras, de ligar o comportamento de Homossexuais à Aids - é capaz de configurar e reforçar processos narrativos acerca da infecção. Sontag (1989) teoriza, embora compreenda como um processo previsível, visto em seu trabalho sobre a doença como metáfora (1984), as sucessíveis doenças com suas sucessíveis metáforas, a exemplo da tuberculose e o câncer explicados no começo dessa seção, que "em se tratando de uma doença ainda não inteiramente conhecida, além de extremamente resistente a tratamentos, o advento desta nova e terrível doença [...] proporcionou uma excelente oportunidade para a metaforização da moléstia (SONTAG, 1989, p. $48)$.

A Aids como metáfora, de acordo com Sontag (1989), é vista como um duplo processo. Por um lado, enquadra-se como microprocesso, a Aids é encarada como um câncer, ou seja, como uma invasão ao corpo e uma multiplicação incontrolável do vírus. Por outro lado, quando se muda o foco de análise e enfatiza-se a transmissão da doença, retoma-se como uma metáfora mais antiga, relembrada também a partir das narrativas sobre a sífilis, a da poluição (SONTAG, 1989, p. 48). A poluição é construída pela propagação do vírus através do sangue ou dos fluídos sexuais de pessoas infectadas (SONTAG, 1989, p. 48). Assim, o corpo, ou o conjunto de corpos, é marcado como poluído, como impuro, enquanto a pureza, a não poluição, para além de representar a inexistência de infecções metaforizadas nos corpos, retoma à concepção de alinhamento aos costumes heterossexuais e cristão.

A Aids é um estado clínico e social do tempo (SONTAG, 1989). A progressão desse estado clínico pode ser muito rápida quando existem uma certa densidade de sintomas, como as doenças oportunistas mais comuns, a exemplo de um raro tipo de câncer na pele, o Sarcoma de Kaposi, e um tipo de pneumonia (SONTAG, 1989). A partir dessa variedade de sintomas, o paciente torna-se cada vez mais fraco, indefeso, incapacitado e desconfigurado por conta dos efeitos das doenças e infecções oportunistas. Desse estado clínico, o estado social torna-se visível. Reconhece-se em uma enfermaria os pacientes com Aids e, com exceção dos cuidados hospitalares, o distanciamento social desse paciente torna-se ainda mais 
evidente (SONTAG, 1989; TIMERMAN e MAGALHÃES, 2015). A invisibilidade do HIV torna-se a Aids visível nos corpos. O passaporte é carimbado e essas pessoas são transportadas para o Reino da doença (SONTAG, 1989), acolhendo todas as metáforas que lhes são reservadas. Diferente da mitologia acerca da tuberculose ou do câncer, "a Aids não dá margem a idealizações românticas, sentimentais, talvez por demasiadamente forte a associação entre doença e morte" (SONTAG, 1989, p. 50). Apoiada nessa forte associação, incorpora-se às narrativas do HIV e da Aids uma importante metonímia, a associação direta de Aids e Morte. No circuito dos afetos, transitam paixões capazes de deixar pessoas que vivem com HIV tristes, ao menos no primeiro contato com o exame sorológico (TIMERMAN e MAGALHÃES, 2015). As narrativas sobre a Aids movimentam tristes paixões, pois "a doença que representa uma censura genérica à vida e à esperança é a Aids" (SONTAG, 1989, p. 50).

É importante enfatizar que a época na qual Susan Sontag escreveu a Aids e suas metáforas, no final da década de 1980, o HIV e a Aids representava um diagnóstico diferente do qual eu escrevo, no ano de 2020 e 2021. Naquela década, a maioria das pessoas com Aids morria, tratava-se um diagnóstico certeiro, pois era uma época sem tratamentos eficazes em um horizonte perto, e mesmo quando as primeiras medicações apareceram, elas provocavam fortes efeitos colaterais nos corpos (SONTAG, 1989; BARATA, 2006; TIMERMAN e MAGALHÃES, 2015).

Como usado naqueles tempos e ainda representado para descrever quem estaria mais propício para desenvolver sintomas de infecções, Sontag (1989) narra que "contrair Aids equivale precisamente a descobrir - ao menos na maioria dos casos até agora - que se faz parte de um determinado 'grupo de risco' ${ }^{23}$, uma comunidade de párias". Ou seja, a doença expunha

uma identidade que poderia ter permanecido oculta dos vizinhos, colegas de trabalho, familiares e amigos. Ao mesmo tempo, confirma uma identidade e, no grupo de risco mais atingido nos Estados Unidos num primeiro momento, o dos homossexuais masculinos, chegou a dar origem a uma comunidade, bem como a uma experiência que isola e expõe os doentes a discriminações e perseguições. (SONTAG, 1989, p. 51)

\footnotetext{
${ }^{23}$ Ênfase de Susan Sontag (1989). Para a autora, “a Aids é concebida de maneira pré-moderna como uma doença provocada pelo indivíduo enquanto tal e enquanto membro de algum "grupo de risco" - essa categoria burocrática, aparentemente neutra, que também ressuscita a ideia arcaica de uma comunidade poluída para a qual a doença representa uma condenação" (SONTAG, 1989, p. 60).
} 
A Aids, por representar também figuras de linguagem nas narrativas sobre si própria, construiu as pessoas infectadas como pertencentes a essa "comunidade de párias" - principalmente às pessoas enquadradas e classificadas pelos $5 \mathrm{H}$ - e essa exposição, descrita por Sontag (1989), permitiu revelar o que Ahmed (2014) compreendeu mais tarde que "diferentes figuras são 'grudadas' a determinadas emoções, e esse 'ato de grudar' depende de histórias passadas de associação que muitas vezes são ocultadas"24 (AHMED, 2014, p. 12-13). Nessa exposição, de descobrir certa identidade oculta dos "vizinhos, colegas de trabalho, familiares e amigos" (SONTAG, 1989, p. 51), a identidade exposta, a suposição da homossexualidade, advém da infecção do HIV e da posterior transformação ao estado clínico da Aids. A figura do homossexual ficou grudada nas narrativas do HIV e da Aids como sujeito para além da representação do "grupo de risco", mas principalmente como um dos principais responsáveis pela infecção (GRMEK, 1995; SONTAG, 1989). Por onde os corpos homossexuais caminhavam, mesmo livre da infecção, elas, as narrativas sobre o HIV e a Aids, acompanhavam-nos de mãos dadas.

A Aids foi narrada como uma condenação à morte. Sua associação metonímica, associar Aids à morte, espelhou a face da infecção. Tratava-se "apenas de uma questão de tempo" (SONTAG, 1989, p. 53). Nessa relação de condenação, condenava-se as pessoas pelas ações de afastar-se dela a partir de suas impressões: "pessoas estão sendo despedidas quando vem à tona que são portadoras do HIV, de modo que os portadores devem sentir-se fortemente tentados a esconder o fato" (SONTAG, 1989, p. 53). Cruza-se semelhanças com o câncer. Se por um lado, o câncer era mantido em segredo pelos familiares e não revelado ao próprio paciente seu diagnóstico, o movimento inverso tornou-se ferramenta de segurança pelas pessoas com HIV, "o mais comum é o paciente não revelar o fato a seus familiares" (SONTAG, 1989, p. 54). As histórias envolvidas na exclusão do seio social de corpos infectados, negação, muitas vezes, da própria sobrevivência ao vincular-se a um trabalho, reforçava a urgência de manter os afetos e as emoções envolvidas pela descoberta e pelo desenvolvimento do HIV e da Aids à própria intimidade.

\footnotetext{
${ }^{24}$ Tradução livre. No original: "I examine how different 'figures' get stuck together, and how sticking is dependent on past histories of association that often 'work' through concealment. The emotionality of texts is one way of describing how texts are 'moving', or how they generate effects."
} 
Estar inserido nas narrativas do HIV e da Aids independe do status sorológico, pois a construção dessa narratividade não diferencia o status, senão aglutina as comunidades, provocando o movimento de aproximação e de afastamento em relação a esse corpo (AHMED, 2014). Esse afastamento ocorre pela perspectiva de transmissão da infecção. O HIV e a Aids são encarados como uma "calamidade da qual a própria vítima é culpada, é mais censurada do que a de outras - particularmente porque a Aids é vista como uma doença causada não apenas pelos excessos sexuais, mas também pela perversão sexual" (SONTAG, 1989, p. 51). Os afetos e emoções mobilizados e circulados pelas narrativas edificam as fronteiras dos relacionamentos. Os afetos e as emoções propagadas pelas narrativas moldam as superfícies dos corpos individuais e coletivos, e por isso criam-se orientações em relação aos outros: afastar-se, aproximar-se. Somos moldados a partir do contato com o outro e por histórias de contato com o outro e movidos por narrativas que "grudam" emoções em determinados outros. Nesse exemplo sobre perversão sexual, embora Sontag (1989) não explicite a fundo o que é uma perversão sexual, muito menos quais corpos estão figurados como perpetradores de perversão sexual, atribui-se à vítima a culpa pela manifestação do HIV e da Aids. Por um lado, enquanto outras pessoas com HIV não são consideradas como responsáveis pela infecção, a exemplo dos "hemofílicos e pacientes que receberam transfusões de sangue" (SONTAG, 1989, p. 51), por outro, essas pessoas "são por vezes tão discriminados quanto os outros, por pessoas amedrontadas, e potencialmente representam uma ameaça ainda maior, pois, ao contrário dos que já estão estigmatizados, são mais difíceis de ser identificados" (SONTAG, 1989, p. 52). A orientação dos corpos, por vez, não se apoia unilateralmente nos homossexuais, por exemplo, senão pela própria infecção do HIV e da Aids. As narrativas sobre a infecção circulam afetos e emoções, narram com o tempo, e com o acolhimento dessas versões na sociedade, os personagens dessa epidemia, desfigurando e escondendo as práticas vulneráveis.

Uma das metáforas mais recorrentes nas narrativas do HIV e da Aids referese à compreensão da epidemia como a "peste", pois "as epidemias são consideradas pestes" (SONTAG, 1989, p. 59). Sontag (1989) relembra a fala de Cotton Mather, pregador e escritor puritano, concebendo a Aids como uma espécie de peste, uma condenação moral da sociedade. Além de dois destacados religiosos brasileiros, “o cardeal-arcebispo de Brasília, d. José Falcão, para quem a aids é 'consequência da 
decadência moral', e o cardeal-arcebispo do Rio de Janeiro, d. Eugênio Sales, que vê na Aids ao mesmo tempo um 'castigo de Deus' e 'a vingança da natureza"” (SONTAG, 1989, p. 66). Trinta anos depois desses escritos de Susan Sontag, as narrativas sobre o HIV e a Aids vinculadas a um "castigo divino" continuam presente por novos atores importantes de comunidades religiosas. Em setembro de 2020, a cantora e pastora Ana Paula Valadão disse que "a Aids está aí para mostrar que a união sexual entre dois homens causa uma enfermidade que leva à morte" (LERAY, 2020). Ao que tudo indica, Ana Paula Valadão será indiciada pelo crime de LGBTfobia a partir de denúncias feitas por ONGs ativas na proteção de direitos LGBTQIA+ (LERAY, 2020). Em suma, a construção metafórica de peste nas narrativas sobre a infecção reforça "a ideia de que a Aids vem castigar comportamentos divergentes [...] e que ela permite que uma doença seja encarada ao mesmo tempo como castigo merecido por um grupo de "outros" 25 vulneráveis e como uma doença que potencialmente ameaça a todos" (SONTAG, 1989, p. 66).

A Aids foi entendida como um interesse extremamente relevante dentro do fenômeno midiático ao se relacionar simultaneamente com o global e o local, nesse comportamento previsível de uma epidemia (BARDHAN, 2001, p. 284). Ao contrário de uma narrativa ficcional, construída sobre um arquivo digital, como o e-book, ou analógico, como o livro em papel, ou até mesmo oral, como o audiolivro, seu universo não é limitado a um começo e a um fim. O HIV e a Aids, assim como o desenvolvimento de suas narrativas, não se construíram em cima de um começo delimitado, muito menos apresentou um fim. Essa relação tornou-se desafiadora para a autoridade biomédica (BARDHAN, 2001).

A rede transnacional de notícias teve problemas éticos em capturar as complexidades da epidemia, como foi elucidado nos componentes das narrativas dessa infecção, e atribui-se certa responsabilidade à mídia por suas manifestações incertas (BARDHAN, 2001, p. 284-85). Um dos caminhos adotados ao estudo midiático do HIV e da Aids é direcionar as reflexões ao tipo de enquadramento (frame) utilizado nas narrativas. Algumas perguntas são levantadas: “Qual é o quadro (frame) aqui? Por que esse e não outro? Quais padrões são compartilhados pelos quadros fixados sobre este evento e os quadros presos sobre aquele, por quadros de mídias diferentes de diferentes lugares e diferentes momentos?"

\footnotetext{
${ }^{25}$ Ênfase de Susan Sontag (1989).
} 
(ENTMAN, 1991 apud BARDHAN, 2001). Em suma, Entman (1991) indaga que os quadros emergentes como dominantes ao longo do tempo trazem implicações significativas para a atitude do público, as interpretações culturais e os resultados de políticas. Compreendo que o processo midiático é uma construção conjunta com o pensamento de uma sociedade, com seus próprios circuitos afetivos, e que moldou as narrativas do HIV e da Aids com os quadros apresentados primeiramente à sociedade por autoridades sanitárias, reinterpretadas por seus próprios saberes e crenças e reproduzindo essas narrativas. O enquadramento adotado para informar a população sobre o HIV e a Aids, para além das descobertas científicas, que já influenciavam narrativas sobre a transmissão do vírus e dos grupos determinados como possíveis propagadores da infecção, refletiu interpretações e crenças que já circulavam acerca de doenças infecciosas e acerca de determinados "outros" em diferentes contextos.

Assim, enquanto nos Estados Unidos houve uma forte tendência em atribuir a "culpa" da origem do HIV e da Aids aos estrangeiros, principalmente a responsabilização ao continente africano no primeiro momento (SONTAG, 1989; BARATA, 2006), houve um movimento midiático africano de reação às acusações recebidas pelo enquadramento midiático ocidental. Mas, a culpabilização não ocorreu apenas por parte da África. A França e a Alemanha acusaram os Estados Unidos que, por sua vez, após cogitar o surgimento do vírus no continente africano, atribuiu culpa ao Haiti, principalmente pela descoberta de haitianos vivendo com HIV em território estadunidense. Inclusive a ex-União Soviética sugeriu que o vírus foi criado pelos estadunidenses em algumas unidades de inteligência para ser usado como meio de guerra biológica (GILMA, 1988 apud BARDHAN, 2001) ou através da reprodução de rumores de que o vírus do HIV foi inventando dos Estados Unidos em um laboratório militar (HELLER, 2015). Em muitos países asiáticos, a cobertura midiática consistiu em temas de negação, atribuição de culpa ao outro, sem contar com o controle dos sistemas de imprensa em alguns países (BARDHAN, 2001). Em suma, a internacionalização da pauta tornou-se também uma ramificação de estudos sobre a comunicação em massa através das notícias sobre o HIV e a Aids (GRUBE e BOEHME-DUERR, 1988, p. 686).

O tópico mais importante a ser abordado na construção das narrativas sobre o HIV e a Aids, seja por falas de religiosos reconhecidos, seja pelas primeiras interpretações sobre a origem e o desenvolvimento da infecção, leva em 
consideração o papel da mídia na difusão e na criação de parte dessas narrativas. Ao ser apresentada no Brasil, a infecção do HIV e da Aids teve como a principal fonte de informação da população a televisão (BARATA, 2006, p. 6). Muito antes de os pesquisadores e o governo terem segurança científica sobre o assunto, as informações descritivas sobre o HIV e a Aids já começavam a ganhar presença nas falas cotidianas. Um dos primeiros espaços ocupados pela retratação dos primeiros casos no mundo e no Brasil aconteceu pelo Fantástico, programa jornalístico, exibido na Globo aos domingos de noite, pioneiro na divulgação do nome da Aids ao exibir, pela primeira vez, em 27 de março de 1983 uma reportagem intitulada “epidemia do século", introduzindo os primeiros panoramas da epidemia de HIV nos Estados Unidos e a possível expansão para o Brasil (BARATA, 2006, p. 7). A autora ainda reforça que o espaço no Fantástico dedicado à Aids advém das primeiras características encontradas na infecção, seu desconhecimento, sobretudo, sua mortalidade e sua transmissibilidade por via sexual foram relevantes ao enquadramento jornalístico executado pelo Fantástico na década de 1980, quando o programa valorizava as histórias extraordinárias, bizarras e grotescas, inspiradas no gênero fait divers ${ }^{26}$, em uma busca frenética por fatos pitorescos para entreter o público (BARATA, 2006, p. 7).

As pautas relacionadas à Aids e apresentadas pelo programa Fantástico se basearam principalmente nos elementos ilustrados na Tabela I:

Tabela I: Pautas no Fantástico sobre o HIV e a Aids

\begin{tabular}{|l|l|}
\hline \multicolumn{1}{|c|}{ Pauta } & \multicolumn{1}{c|}{ Descrição } \\
\hline Eventos & Eventos científicos; dia internacional da Aids; manifestações públicas; \\
\hline Novidades & $\begin{array}{l}\text { Descobertas científicas; desenvolvimento de medicamentos, testes; } \\
\text { primeiro hospital do mundo para tratar a doença; }\end{array}$ \\
\hline Estatísticas & $\begin{array}{l}\text { Nos chamados grupos de risco (homossexuais, usuários de drogas } \\
\text { injetáveis e hemofílicos, sobretudo), em presidiários, entre mulheres e } \\
\text { heterossexuais; distribuição da doença nas diferentes regiões do país; }\end{array}$ \\
\hline
\end{tabular}

\footnotetext{
${ }^{26}$ Como relata Barata (2006), "O fait divers proporciona assuntos que desviem da norma, levando o público a sentir-se melhor sobre si mesmo e descompromissando o autor da responsabilidade de analisar a história, ou seja, ao narrador cabe o papel de simplesmente mostrar/contar esta história" (BARATA, 2006, p. 19).
} 


\begin{tabular}{|l|l|}
\hline Interesse Público & $\begin{array}{l}\text { Nova legislação; situação dos hospitais públicos; falta de controle em } \\
\text { bancos de sangue; campanhas de saúde; educação sexual; comportamento } \\
\text { de risco; sexo seguro; }\end{array}$ \\
\hline $\begin{array}{l}\text { Fatos pouco } \\
\text { comuns }\end{array}$ & $\begin{array}{l}\text { Jovem se casa com portador de Aids; crianças portadoras do vírus da Aids } \\
\text { sofrem preconceito; infecção de enfermeiras; julgamento de homem que } \\
\text { tenta doar sangue mesmo sabendo ser soropositivo; pacto entre } \\
\text { portadores da Aids para disseminar o vírus; pessoa que contrai o vírus no } \\
\text { dentista; }\end{array}$ \\
\hline Personalidades & $\begin{array}{l}\text { Morte de celebridades como Lauro Corona, Freddy Mercury; anúncio de } \\
\text { infecção de pessoas conhecidas como Herbert de Souza, Magic Johnson, } \\
\text { Rock Hudson; festival de música em benefício das vítimas de Aids. }\end{array}$ \\
\hline
\end{tabular}

Fonte: Elaboração do autor a partir de BARATA, 2006, p. 106.

Construindo reportagens em cima do gênero fait divers, tornou-se nítida a relação da mídia no fortalecimento de narrativas em relação à infecção, pois mitos e metáforas inseridas nessa construção narrativa eram transmitidos na televisão, fortalecendo, talvez inintencionalmente, os preconceitos e os estigmas contra os pacientes, principalmente àqueles enquadrados em um "grupo de risco" (BARATA, 2006, p.7). Como visto, Passos e Barros (2009) advertiram das implicações em classificar pessoas, formadas por suas próprias narrativas complexas, em grupos de riscos, ao invés de direcionar à impessoalização, à existência de práticas vulneráveis para a infecção. A mídia, além de tornar mais intrínseco esse papel, contribuiu para "distanciar o telespectador da realidade da doença" (BARATA, 2006, p.7), ou seja, o telespectador, isento de enquadramento, afastou-se do problema sanitário retratado naquele momento e criou, como manifestação dos afetos e emoções ligadas à narrativa do HIV e da Aids, um distanciamento em relação aos corpos infectados.

A construção da narrativa do fait divers influencia a circulação dos afetos e das emoções dos telespectadores ao utilizar expressões linguísticas de considerável impacto: "assunto grave, doença misteriosa, epidemia mais violenta, mal fulminante, avanço assustador, resultado dramático, estatísticas estarrecedoras, esperança na luta, melhores perspectivas" (BARATA, 2006, p. 108). Cria-se uma atmosfera dramática, apreensiva, indagadora para os ouvintes que estão inseridos nos holofotes dos "grupos de risco", como a todos os que têm consciência, nesse primeiro momento, sobre a possibilidade de qualquer um se infectar. As imagens ilustradas do HIV e da Aids na televisão ajudam a traduzir os elementos escritos 
em elementos visuais, a exemplo da sequência de imagens de hospitais e laboratórios, equipamentos hospitalares, como se todas essas expressões estivessem presentes nas narrativas visuais da infecção. O mistério era desenhado por músicas de suspense e por esses cortes de figuras hospitalares e de pessoas deitadas em macas. A Aids é descrita, construída sobre narrativas headlines, como:

\footnotetext{
'doença misteriosa', 'totalmente desconhecida há dois anos', 'epidemia mais violenta do século', 'a Aids é fatal', 'mal fulminante', 'mais implacável que a leucemia e mais contagiosa que a hepatite', 'doença terrível', 'nova doença', 'a doença que vem assustando o mundo inteiro', 'o chamado câncer gay', 'doença que destrói as defesas naturais do organismo', 'epidemia'. (BARATA, 2006, p. 115)
}

As chamadas de atenção, desconectadas em partes da função de responsabilidade social da mídia, serviram para circular afetos e emoções específicos na população. Em geral, a adjetivação nas narrativas serviu para impulsionar o medo, o pânico e concretizar a metáfora do mistério e do medo da morte em relação à "nova doença fatal” (BARATA, 2006, p. 115).

É certo, as primeiras notícias divulgadas acerca da doença letal ajudaram a construir "o imaginário da doença na população e moldaram ou reforçaram o comportamento social diante da doença e de seus pacientes" (BARATA, 2006, p. 12). Os meios de comunicação fizeram parte da construção narrativa histórica do HIV e da Aids. Desse desenvolvimento da infecção até 1985, a agenda governamental brasileira não incluía o HIV e a Aids como "ameaça" à população, pois ainda era visto como "doença de ocorrências isoladas, restrita a segmentos sociais específicos", mas com o aparecimento de casos no Brasil, estabeleceram-se as diretrizes para o Programa de Controle da Aids, ao passo que já circulavam as vagas informações e desinformações na mídia (BARATA, 2006, p. 16). Mas, a mídia também se viu diante de um desafio. Era necessário, embora não fosse possível controlar seus efeitos e suas interpretações, falar sobre a infecção de uma forma responsável, capaz de informar sem inflamar e educar sem alardear (BARATA, 2006). Era necessário "um equilíbrio entre tratar a questão pelo viés da moralidade, condenando os comportamentos dos grupos mais infectados pelo HIV, e o da saúde pública, procurando garantir aos infectados uma qualidade de vida e tratamento médico" (BARATA, 2006, p. 16). O quadro narrativo do HIV e da Aids pela mídia, e pelas primeiras abordagens do governo (PASSOS e BARROS, 2009), 
construiu-se sobre alertas a grupos específicos, implicando-lhes questões morais, e sobre a busca por ampará-los em um momento incerto do desenvolvimento da infecção.

Nos Estados Unidos, nos primeiros sinais da Aids, a imprensa já manifestava suas primeiras metáforas e metonímias narrativas, batizando-a como "câncer gay" ou "pneumonia gay" (TIMERMAN e MAGALHÃES, 2015), por isso a adoção, mais tarde, da sigla DIRG, Doença Imunológica Relacionada aos Gay. Nas manifestações midiáticas mais conservadoras, a narrativa se construía pela "peste gay". Reforçando, Sontag (1989) já afirmava que a construção narrativa de "peste" que afligia a comunidade de pessoas com a doença implicava uma forma de castigo (SONTAG, 1989; BARATA, 2006).

Um adendo, a metáfora do "câncer gay", junto com essas outras expressões linguísticas associadas à comunidade homossexual, representou imageticamente a figura da Aids como estado clínico, pois os pacientes imunodeprimidos desenvolviam, como mencionado acima, um tipo de câncer causador de úlceras na pele, o sarcoma de Kaposi (BARATA, 2006, p. 38). Na mais fiel imagem de um médico que trabalhou nos primeiros momentos da manifestação e expansão clínica da Aids no Brasil, percebe-se como a influência da metáfora "câncer gay" ganhou os palcos e as telas em um primeiro momento:

a imagem das alas hospitalares ocupadas por pacientes com AIDS era muito triste. Homens jovens, a maioria na faixa dos 30 anos, com o rosto cadavérico e o corpo consumido pela doença. Tinham a pele descamando, o cabelo ralo e as unhas tomadas por micose - sintomas da debilidade imunológica. Muitos estavam com pernas, braços, tronco e até o rosto tomados por manchas protuberantes em tom vermelho, arroxeado ou marrom, características do câncer de pele que acometia os primeiros pacientes de AIDS, chamado sarcoma de Kaposi. Alguns queixavam-se de visão turva ou estavam já cegos, vitimados por um vírus de nome complicado, da família do herpes, que não causa mal algum a pessoas saudáveis, mas pode deixar sequelas em sujeitos com a imunidade altamente comprometida. Tossiam muito, devido a tuberculose. A pneumonia lhes tirava o ar. Quando a depressão ou infecções atingiam o cérebro, deixavam os sujeitos fora de sintonia. Durante os primeiros 10 anos de epidemia, não tínhamos muito o que oferecer além de cuidados de fim de vida. (TIMERMAN e MAGALHÃES, 2015, p. 8)

Desse relato, observo que as narrativas do HIV e da Aids não estão flutuando no vazio. Associam-se a uma realidade material, nesse caso, à realidade encontrada 
nos hospitais, nas alas específicas para pacientes apresentando algum tipo de sintoma ou doença relacionada a esse estado clínico. O "câncer gay" se materializa na manifestação clínica do sarcoma de Kaposi sobre corpos homossexuais. De corpos excluídos da sociedade, em que já lhes eram atribuídas rejeição e impureza por suas práticas desviantes dos dogmas cristãos, impulsionou-se uma das primeiras narrativas sobre o HIV e a Aids. Aos homossexuais, restou-lhes chorar por seus mortos e transformar seu luto em movimento (AHMED, 2014).

A imagem construída a partir do texto escrito por Artur Timerman representa uma singularidade narrativa de quem viveu esse momento atuando na linha de frente dessa infecção até então pouco conhecida. Essas relações descritas com os pacientes, em suma, repletas de singularidades generalizadas, são capazes de manifestar afetos e emoções em pessoas que vivem com HIV ou de seus conhecidos. Essa época, descrita pelo médico, remonta a um tempo pouco imaginável de uma representação do HIV e da Aids se comparada à acessibilidade de prevenção e tratamento encontrada hoje, em 2021. Artur Timerman narrava acima de tudo sobre cuidados paliativos. Tratava-se o fim da vida, as doenças oportunistas. A pergunta que se coloca, mesmo conscientes da existência de uma cadeia de prevenção e tratamento capaz de tornar o HIV e a Aids uma infecção crônica, não mais a uma sentença de morte, é: por que as imagens que registramos sobre o HIV e a Aids ainda remontam a essas épocas distantes de hoje? Por que ainda existe esse imaginário mortífero e persistente do HIV e da Aids?

Ao que parece, a mortalidade gerada no começo da infecção continua persistente em narrativas, a ponto de relacioná-la metonimicamente à infecção: Aids é morte. Embora saibamos que a realidade não é mais essa, a realidade de quem tem acesso à prevenção e ao tratamento contínuo, a mortalidade foi um dos maiores temores narrados pelo HIV e pela Aids. Talvez este relato de Artur Timerman nos induza a outra imagem narrativa:

fazia as visitar sempre acompanhado da minha maleta, que tinha basicamente estetoscópio, aparelhos de medir a pressão, termômetro, abaixador de língua, caneta, receituário, carimbo e uma folha de atestado de óbito que eu deixava bem lá no fundo, escondida. De repente, com a epidemia de AIDS, vi-me fazendo visitas domésticas com muito mais frequência e já levava um bloco inteiro de atestados de óbito comigo - e, pior, sabia que iria usá-los em pouco tempo. Quando tocava o meu bip - o código 
era 27BK, ainda me lembro -, a primeira coisa que eu pensava era: "quem morreu? (TIMERMAN e MAGALHÃES, 2015, p. 8)

Os atestados de óbito tornaram-se, infelizmente, frequentes para quem descobria o vírus do HIV em seu corpo. Artur Timerman continuou a usar seus atestados de óbitos em pacientes com Aids. Ele continua:

depois de algum tempo nessa toada, recebi uma carta da administração do Hospital das Clínicas solicitando que eu comparecesse à diretoria para resolver um problema do meu interesse. Chegando lá, o diretor pediu que eu justificasse aquela situação totalmente anormal - lembro-me dele dizendo que, nos dois meses anteriores, eu tinha usado 45 folhas de atestado de óbito do hospital. A desconfiança era de que eu estaria vendendo aqueles documentos. Expliquei a situação. Falei que todos os casos eram de pacientes que eu acompanhava e que haviam morrido em sua própria residência. Ele, então, perguntou: Todos tinham Aids como causa da morte? Eu respondi: - Quase todos. Em alguns casos, atendi à solicitação da família e omiti o diagnóstico. O 'pecado' que eu poderia ter cometido era esse. Para alguns dos pacientes, anotei como causa da morte 'tuberculose', 'pneumonia', 'neurotoxoplasmose' ou alguma outra infecção oportunista que a pessoa tinha tido, em função da AIDS. Ou, então, usei apenas a palavra 'imunodepressão'. O grande complicador, naquela época, era escrever, com todas as letras, 'síndrome da imunodeficiência adquirida', seguido da sigla 'AIDS'. Havia companhias que se recusavam a pagar o seguro de vida às famílias se a causa da morte do segurado fosse a síndrome. Havia muito estigma em relação à doença. (TIMERMAN e MAGALHÃES, 2015, p. 8-9)

Assim, colocar no atestado de óbito a causa como "AIDS" significava condenar o corpo do paciente mesmo depois de sua morte, em uma época quando a infecção representava um castigo e uma inquietude moral. Era revelar segredos. Revelar alguns corpos que sempre se esconderam e que foram expostos à família, à sociedade, como castigados. As narrativas tiveram um papel muito forte de perpetuar essa relação nesse tempo.

Como toda narrativa, a ilustração dos personagens responsáveis por envolverem-se nos conflitos, nesse caso o HIV e a Aids, pessoaliza e intensifica a realidade das doenças. A partir de um cruzamento de dados, o CDC, Centro de Controle e Prevenção de Doenças dos Estados Unidos, identificou quem, supostamente, seria o "paciente 0" do HIV e da Aids nos Estados Unidos. Embora tenha sido desmentido mais tarde por estudos genéticos, Gaëtan Dugas foi considerado pelo CDC o primeiro personagem dessa narrativa (TIMERMAN e 
MAGALHÃES, 2015). Enquadrado nos sintomas da DIRG, Gäetan foi facilmente assimilado como uma manifestação "real" das narrativas já vinculadas acerca dos homossexuais. Era um comissário de bordo franco-canadense que tinha como hábito frequentar saunas em São Francisco, Los Angeles e Nova York, as cidades que frequentava por conta de seu ofício. O CDC concluiu que Gäetan Dugas estava conectado a pelo menos 40 dos quase 300 casos de Aids identificado no primeiro ano da epidemia (TIMERMAN e MAGALHÃES, 2015, p. 44). Essas quarenta pessoas tiveram, em algum momento, relações sexuais com Gäetan. A vida sexual de Gäetan Dugas foi ilustrada como "promíscua" pelo número de pessoas a quem estava conectado com a infecção, adicionando elementos importantes às narrativas sobre o HIV e a Aids nesse período e em épocas subsequentes. O fato é que Gäetan Dugas, independente das ações de sua vida privada, sentiu as manifestações afetivas e emotivas por ser apontado como "paciente 0", que se fosse um romance, seria visto como o vilão de toda essa história. A demonização de seu personagem se construiu. Anos mais tarde, o equívoco de sua classificação foi revelando. Ao relacioná-lo como "paciente 0", não se atentaram que,no seu exame, havia a vogal "O" ao lado de paciente, e não o algarismo "0". Ao invés de considerá-lo como "paciente O", significando "paciente Out-of-California", interpretaram como “paciente 0", a origem de todo mal na América (MATTEO, 2020).

Douguie, como era conhecido Gaëtan Dugas, foi um dos personagens ilustrados nas narrativas do HIV e da Aids. Posteriormente, a mídia atentava-se aos famosos, pessoas conhecidas de diversas áreas, infectadas pelo HIV e pela Aids. Algumas foram rapidamente associadas à homossexualidade, como o emblemático Farrokh Bulsara, cuja narrativa nessa trajetória se reproduziu por outras formas de manifestação artística e entretenimento, a exemplo do filme Bohemian Rhapsody, longa-metragem biográfico do vocalista da banca de rock Queen, mais conhecido como Freddie Mercury. Os personagens do HIV e da Aids transcendiam o anonimato da infecção e aproximavam-se cada vez mais da população (TIMERMAN e MAGALHÃES, 2015). Aproximavam-se porque o HIV e a Aids deixavam de representar uma infecção distanciada, pertencente a um grupo seleto de párias (SONTAG, 1989), e começavam a se manifestar em personalidades conhecidas e amadas pelo público. O circuito dos afetos, que já ligava fãs aos seus objetos de identificação e investimento afetivo, manifestava novas paixões ao focalizar, com uma luz condenatória, a própria personalidade infectada pelo HIV e, 
com o tempo, na condição clínica expressa pela Aids. Há dor, medo, distanciamento, tristeza, revolta. As emoções manifestadas pelos fãs, pelas pessoas conectadas, embora apenas pelo conhecimento de sua existência, implicam aos corpos uma decisão: afastar-se ou aproximar-se. Na incerteza da decisão, a solidão pairava.

Não se pode desconsiderar que a contração do vírus pela estrela hollywoodiana Rock Hudson alavancou os tabloides e acalentou as narrativas sobre o HIV e a Aids na mídia, tornando um evento essa revelação (BARDHAN, 2001, p. 290). Entretanto, a conexão de Rock Hudson ao HIV e à Aids não foi uma surpresa para muitos fãs e conhecedores dessa estrela, porque Rock Hudson já tinha um histórico semelhante àquele adotado pelas narrativas: uma lista de contatos sexuais com homossexuais. A divulgação de seu status sorológico não foi uma surpresa, pois ele já estava enquadrado no chamado "grupo de risco" e, assim, não desencadeou um medo popular. E com o aparecimento do HIV e da Aids, acreditouse ser "esperado" que algo dessa natureza pudesse lhe ocorrer (BARDHAN, 2001, p. 290). O fato é que Rock Hudson, independentemente de seu histórico e de suas paixões, representou uma dupla guinada no início das narrativas sobre a infecção. De um lado, tornou-se peça-chave para ilustrar que o vírus infectava pessoas incluídas na construção de um grupo de risco, focalizando o seu corpo, já incluído nos holofotes de Hollywood, para além de seu trabalho artístico, incluindo-o na comunidade de corpos excluídos. Por outro lado, embora não seja uma grande revelação a sua aquisição viral, Rock Hudson desdobrou as narrativas da infecção ao torná-las sem fronteiras, pois o vírus atingiria outras estrelas, e alegou que o vírus circulava com veracidade: o HIV era real, a Aids se tornaria real para Hudson. Além disso, Rock Hudson preenchia um dos requisitos importantes quando a mídia começou a ter muitas pautas sobre a epidemia: uma pauta de destaque. Segundo um repórter de Nova York, durante uma convenção em Atlanta em 1994, para noticiar o HIV e a Aids "você tem que trabalhar mais duro quando estiver vendendo uma história de Aids, porque ela existe há muito tempo. Editores dirão que estão cansados de ouvir isso"27 (HERNANDEZ, 1994 apud BARDHAN, 2001, p. 292).

No Brasil, o personagem ilustrado com essa infecção foi o estilista Marcos Vinicius Resende Gonçalves, mais conhecido como Markito (SILVA e GUEDES,

\footnotetext{
${ }^{27}$ Tradução livre. No original: "you have to work harder when you're selling an Aids story, because it's been around for so long. Editors will tell you they're tired of hearing it".
} 
2020). Ele tornou-se o marco zero da ameaça da Aids (BARATA, 2006, p. 100).

Por representar grande relevância em seu mundo, totalmente vinculado ao mundo artístico e midiático, principalmente por ter vestido "socialites e atrizes, Pat Cliveland, Zezé Mota e cantores e cantoras como Ney Matogrosso, Diana Ross, Simone, Gal Costa e Fafá de Belém" (SILVA e GUEDES, 2020, p. 9), a sua morte por Aids chamou grande atenção da mídia. Se antes, os periódicos Jornal do Brasil, Folha de São Paulo e revistas como Veja e Istoé já ilustravam seus trabalhos, com a sua morte, tornaram-se pioneiras nas manifestações narrativas do HIV e da Aids. E ela foi anunciada dessa forma no Jornal do Brasil, em 5 de junho de 1983, na página 28 do caderno 1, na seção de falecimentos:

\begin{abstract}
Marcos Vinicius Resende Gonçalves, o Markito, 30, de doença diagnosticada como câncer gay ${ }^{28}$. Em hospital de Nova Iorque, mineiro, de Uberaba, era costureiro e figurinista dos mais famosos do Brasil, chegando a ser chamado de costureiro das estrelas. [...] Vivia há 10 anos em São Paulo e há seis meses começou a ter sintomas da doença. Inicialmente foi tratado pelo médico Paulo Mesquita e depois, aconselhado por outro médico, Jorge Bastos Garcia, a ir se tratar nos Estados Unidos [...]. (SILVA e GUEDES, 2020, p. 9)
\end{abstract}

Por suposto, a morte de Markito foi contada no país a partir da narrativa já conhecida nos Estados Unidos de castigo, reforçando a associação aos homossexuais, outorgando-lhes a culpa pelo mal do século, pela promiscuidade, pelas práticas “desviantes" dos atos sexuais (SILVA e GUEDES, 2020). As notícias em torno de Markito, e a construção do dossiê sobre as narrativas da infecção, tiveram como principal fonte as agências norte-americanas de notícias, assim, as notícias reproduzidas por lá tinham reflexo nos noticiários brasileiros e, por consequência, no imaginário social da doença (BARATA, 2006; SILVA e GUEDES, 2020). Além disso, o jornal "Le Figaro afirmou que a 'Aids era a primeira doença da mídia', demonstrando a grande difusão de notícias pela mídia sobre o assunto e chamando atenção do público para um novo fenômeno social: a Aids-notícia" (SILVA e GUEDES, 2020, p. 5). A Aids, de fato, tornava-se um produto midiático com o teor sensacionalista nas suas primeiras aparições (BARATA, 2006; TIMERMAN e MAGALHÃES, 2015; SILVA e GUEDES, 2020).

\footnotetext{
${ }^{28}$ Destaque feito por mim, o autor.
} 
Por outro lado, as narrativas precisaram se modificar ao perceber-se, estranhamente, que uma criança apresentava os "sintomas da peste gay" após receber uma transfusão de sangue. Além de anunciar esse caso no final de 1981, o CDC ainda notificou outras crianças imunodeprimidas com infecções oportunistas, sem apresentarem explicações explícitas (TIMERMAN e MAGALHÃES, 2015, p. 44). O HIV e a Aids deixou de ser uma doença destinada a castigar homossexuais e começou a espalhar-se por outros grupos definidos de pessoas, reforçando a barreira entre os contaminados e os não contaminados a partir do "estar ou não incluído e excluído". E por uma vez mais, as práticas vulneráveis de contato com o HIV e a Aids não eram anunciadas como prioritárias para o controle da epidemia, senão apenas a reformulação das fronteiras desses grupos "de risco". A aquiescência de outras pessoas infectadas, para além dos homossexuais, também influenciou a abordagem da mídia para narrar a infecção. Deixou-se a exclusividade discursiva sobre a "praga do homossexual" 29 para incluir, agora, crianças e hemofílicos (BARATA, 2006, p. 116). Desse momento, da percepção não exclusiva do HIV e da Aids aos homossexuais, impõe-se outra concepção da infecção, a "doença dos 5H": homossexuais, hemofílicos, haitianos, heroinômanos e hookers. Além de abranger os possíveis grupos susceptíveis à infecção do HIV, mudou-se também a nomenclatura da infecção, de DIRG para AIDS, nesse mesmo período narrativo. A mudança de nomenclatura, embora pareça, para os olhares menos atentos, uma ressignificação para redirecionar a questão, não produziu efeitos significativos nas narrativas sobre o HIV e a Aids. Deixou-se de ser usado "Doença Imunológica Relacionada aos Gays", acusando-os diretamente de responsabilidade sobre a nova epidemia, para se utilizar "Vírus da Imunodeficiência Humana" (TIMERMAN e MAGALHÃES, 2015). Entretanto, as narrativas já construídas em torno da DIRG estabeleceram-se em bases sólidas, pois, ao surgimento da sigla "HIV", não se criaram novas narrativas em torno do vírus ou novas possibilidades de compreender a incógnita sanitária, senão um deslocamento nada sutil das narrativas. O HIV era a nova DIRG, ao menos nas suas narrativas. Por isso, as metonímias inscritas no HIV são reflexos da DIRG. Associar dois elementos, HIV

\footnotetext{
${ }^{29}$ Um pequeno adendo estatístico dos primeiros anos da epidemia: "de cada 10 pessoas (infectadas), 9 são homens, alguns hemofílicos e outros refugiados haitianos. 25\% são viciados em drogas e certamente usam injeções com agulhas contaminadas, $70 \%$ das vítimas são homossexuais, razão pela qual no início a Aids era chamada de praga do homossexual" (BARATA, 2006, p. 116).
} 
a Gays, é a perpetuação da primeira relação metonímica da DIRG, a nova Doença a Gays. E as metonímias são estruturas importantes na construção das narrativas.

A relação aplicada à ideia de grupos de riscos, vistos já em Passos e Barros (2009), é observar, nesse caso sobre o HIV e a Aids, um conceito cristalizado reservado a um grupo pré-definido de infecciosos, nesse caso os homossexuais (TIMERMAN e MAGALHÃES, 2015). Construir a intocabilidade do conceito e das pessoas susceptíveis à infecção também implica a percepção, ressignificando Ahmed (2014), do aproximar-se e afastar-se. Os heterossexuais sentiram-se imunes à infecção, afastaram-se das formas preventivas e afastaram de si as narrativas não lhes pertencentes, pois era repetido "o mantra de que a AIDS era coisa de homossexual" (TIMERMAN e MAGALHÃES, 2015). Ao mesmo tempo, a significação de "grupo de risco" aproximava todos os envolvidos e lhes impunha as mesmas narrativas. Supunha-se a ideia de "um grupo fechado, de onde ninguém entrava, ninguém saía, todos os que não eram gays se consideravam a salvos" (TIMERMAN e MAGALHÃES, 2015, p. 45). O direcionamento do Estado em lidar com a infecção em um primeiro momento contribuiu fortemente à perpetuação narrativa dos grupos de riscos, porque ao definir os infecciosos definia-se também as barreiras sanitárias: era só não se envolver com esses grupos, excluí-los, se já não eram excluídos, do cotidiano social (PASSOS e BARROS, 2009; TIMERMAN e MAGALHÃES, 2015).

Assim, com a ausência de explicações científicas acuradas para algumas infecções, encaixa-se aqui a construção narrativa de gênero mistério, o início do HIV e da Aids se retratou através de crenças e mitos alimentados através de um dos meios "mais eficientes de disseminação destes sentidos [que] é a imprensa, justificando-se por prestar serviços a ser porta-voz dos cidadãos” (BARATA, 2006, p. 29). Percebo que é revelado, tanto na construção explícita de Barata (2006), quanto nas inflexões de Sontag (1984; 1989), que as narrativas se constroem no e contribuem para o circuito dos afetos de uma sociedade e, assim, são transmitidas e ampliadas para toda sociedade a partir de canais oficiais de manifestações narrativas: a televisão, o rádio, os jornais, as revistas, os livros. Não é uma construção unilateral midiática sobre as metáforas e metonímias do HIV e da Aids, senão a intensificação dessa reprodução já existente na sociedade. Direcionam-se as capacidades imaginativas e criativas na produção de conteúdo para a produção de mitos e imagens específicas dos pacientes com HIV e Aids. Assim, a mídia 
realimenta, reforça e reconstrói os arcabouços descritivos já existentes. Não se trata de responsabilizar a mídia, ou açoitar à população, porque "o fato de esses mitos alimentarem o imaginário popular não é responsabilidade do meio de comunicação apenas, pois ele também é influenciado pelo seu público, em um processo de eco, de reflexo" (BARATA, 2006, p. 53). E como colocam Silva e Guedes (2020), o jornalismo vai contribuir para a percepção do mundo, sendo parte do cotidiano na construção das ideias e opiniões sobre determinados temas e assuntos (SILVA e GUEDES, 2020, p. 5).

A manifestação narrativa por meio dos meios de comunicação foi fonte primária de informação para grande parte da sociedade. Assimilar suas perspectivas e reproduzi-las nos circuitos de afetos tornou-se parte dessa legitimação sobre as metáforas da infecção. Reforça-se, "a TV representa o principal meio esclarecedor da doença entre a população, uma vez que o meio através do qual a sociedade recebeu as primeiras informações a respeito e que pode ter influenciado fortemente a maneira pela qual as pessoas lidaram e se relacionaram com a doenças e os doentes" (BARATA, 2006, p. 59). A aquiescência narrativa implica a manifestações afetivas e emotivas sobre os corpos humanos, dessas manifestações o fato de lidar com "a doença e os doentes" representou a posição do ser diante da enfermidade e com a escolha de afastar-se ou aproximar-se dos doentes, conhecer ou desconhecer ainda mais a infecção, reproduzir ou indagar as suas narrativas. Não podemos esquecer que a manifestação midiática e governamental na abordagem do HIV e da Aids no país também se responsabilizou na concretização dos grupos de riscos e eram eles que estampavam o rosto, inexistente, de um vírus.

A humanização do HIV e da Aids era turva, obscura e distorcida em um primeiro momento. Através das análises levantadas pelos programas do Fantástico, Barata (2006) discorre como a sociedade assistia às pessoas que vivem com HIV. Eram apresentados sobretudo brasileiros, representantes da presença da infecção no território nacional, e apareciam sem rosto e sem identidade, como se estivessem marginalizados e ocultados. A única identificação era as iniciais de seus nomes, ou chamados por nomes fictícios, sendo geralmente filmados de costas, colocando visivelmente apenas uma parte de seu corpo. Eram enxergados pela própria sombra. Nos casos extremos, uma fotografia surgia com seus olhos tapados com uma faixa preta de censura. Era necessário censurar suas identidades por proteção, não apenas contra agressões físicas, mas, principalmente, para mascarar brevemente essa 
identidade sobressalente de viver com HIV e evitar exclusões afetivas, emotivas e espaciais em suas próprias comunidades. Ainda eram tratados e direcionados como "aidéticos". E se não bastasse essa aparição turva de seu corpo como ilustração da infecção, era necessário constrangê-los ainda mais perguntando-lhes como contraíram a doença, apenas para reforçar o julgamento da infecção e de seu caráter culpabilizador. Se apreendessem essas informações e as transformassem em verdadeiras pautas de prevenção e diminuição do avanço do vírus, grande parte da função social da mídia estaria completa. Desses encontros midiáticos, as metáforas e metonímias do HIV e da Aids estavam estampadas no anonimato de seus portadores, pois mostrá-los nessa época era condená-los socialmente pelas narrativas.

Com o tempo, após a primeira fase noticiada do HIV e da Aids, considerada mais atrativa pelos mistérios e enigmas da infecção, além da reunião de polêmicas e das histórias por trás das pessoas infectadas, há uma reinterpretação dos elementos narrativos da Aids (BARATA, 2006, p. 98-100), pois "na tentativa de simplificar e traduzir em palavras e imagens o universo misterioso da doença, os jornalistas americanos criaram expressões, aprofundaram preconceitos e distorções que foram apropriados pela Imprensa brasileira" (BARATA, 2006, p. 99). Embora a imprensa tenha elencado esses elementos, considerados preconceituosos com o tempo, para narrar a infecção, a exemplo da palavra "aidético" para se referir à pessoa com Aids, há uma reinterpretação da abordagem narrativa. Palavras como "aidético", "grupos de risco" e "drogados", foram substituídas respectivamente por "doentes de Aids ou portadores do HIV", "grupos mais expostos ao risco" e "dependentes ou usuários de drogas" (BARATA, 2006, p. 100).

Até aqui, quis descrever parte das narrativas transnacionais do HIV e da Aids que atingiram diretamente as pessoas vivendo com o HIV e do estado clínico da Aids. Foram elas as grandes responsáveis pela manifestação de paixões tristes no início das infecções. Atingiam histórias completas e as reformulavam com perspectivas degradantes das pessoas que tiveram em seu caminho o encontro com o vírus. Essas primeiras narrativas, formadas por inúmeras metáforas e metonímias dos mais diversos grupos sociais, complementam-se com outra abordagem das narrativas de uma infecção: as metáforas de guerra. Sem levar em consideração $a$ priori as pessoas infectadas, senão o vírus como epidemia, orientam-se as narrativas ao combate do inimigo externo (SONTAG, 1984; BARATA, 2006). Alguns dos 
discursos adotados para referir-se ao combate do HIV e da Aids são vistos como metafóricos, a exemplo de:

\begin{abstract}
'encontro dos líderes de 12 países da Europa que vão detonar um plano conjunto de combate à Aids'; 'temos que entrar com urgência na grande batalha internacional contra a Aids'; 'cada um de nós tem células protetoras que funcionam como um verdadeiro soldado no combate aos vírus e bactérias'; 'um bom sistema imunológico pode derrotar o vírus da Aids, mas a tentativa de derrotar o vírus da Aids tem sido uma luta permanente dos pesquisadores'. (BARATA, 2006, p. 137)
\end{abstract}

Mas utilizar essas metáforas militares também ajudam no apaziguamento do medo social gerado durante a apresentação de uma nova epidemia à sociedade, pois demonstra um sentimento de união global em busca da erradicação das dificuldades. Por meio dessas metáforas, "a doença adquire uma dimensão mundial e, pela primeira vez na história das doenças ela passa a ser debatida e a receber uma ação global, criando a perspectiva de aliados que se unem para derrotar o inimigo, um contexto tipicamente militar" (BARATA, 2006, p. 137). Além disso, algumas metáforas militares são usadas quando referidas às perdas humanas. Magic Johnson foi retratado como um soldado da guerra contra a Aids, assim como é usado para ilustrar os cientistas: " um dos soldados de linha de frente da guerra contra a Aids no Brasil é o cientista social Herbert de Souza', além de sempre ilustrar que se infectar com o vírus tornou-se uma 'batalha pela vida'” (BARATA, 2006, p. 137)

As narrativas do HIV e da Aids representaram, como mostrado nessa primeira seção, a articulação de figuras de linguagem, a exemplo das metáforas e das metonímias, para noticiar e tornar a população ciente do surgimento de uma nova epidemia. A princípio, a adjetivação nessas narrativas tornou-se elemento fundamental para mobilizar e direcionar os afetos e as emoções da população, que se viu cercada de paixões tristes: "mistério; enigma; causas desconhecidas; morte"; mas se encontrou aliviada ao perceber a abordagem adotada para indiciar quem "era mais vulnerável à infecção": os homossexuais, uma comunidade de párias já excluída da sociedade. O raciocínio induzido pela criação do "grupo de risco" era muito simples. Se eu não era homossexual, não tinha preocupações. As paixões tristes do começo da epidemia se ressignificaram em ódio, pois agora, os holofotes estavam sobre "os culpados desse mal". Eram realmente holofotes, porque as luzes do HIV e da Aids desmascararam o anonimato de muitos homens, que já tinham 
medo de serem descobertos como homossexuais, e que agora tinham medo de morrer. Com o aparecimento de casos para além da comunidade homossexual, descobriu-se que não eram os homossexuais os únicos vulneráveis. As narrativas da infecção mudaram, mas não a ponto suficiente de livrar os homossexuais de uma culpa inexistente. Grande parte das reportagens no Fantástico sobre o HIV e a Aids tinha três preocupações principais: "atrair audiência, preencher os requisitos de atratividade do gênero fait divers do programa, e fornecer conteúdo com credibilidade e legitimidade" (BARATA, 2006, p. 142). A autora ainda reforça que "as metáforas, mitos, estereótipos, estigmas e preconceitos da Aids divulgados pelo Fantástico refletem e reforçam o inconsciente coletivo" (BARATA, 2006, p. 145). A culpabilização de uma epidemia parece sempre ser necessária para a sociedade, porque faz parte do próprio ato de narrar elucidar o local onde surge o "problema" ou "ameaça" e os personagens envolvidos nessa história a se contar, com seus heróis e vilões. Eram pequenos grupos, muito bem estabelecidos, que se conectavam com o aumento da epidemia. Além dessas narrativas ligadas à individualização da infecção, acontece, no plano Internacional e Nacional, por exemplo, o uso de metáforas de guerra para elaborar diretrizes e ações conjuntas para o enfrentamento de um inimigo comum, nesse caso a Aids. Nesse primeiro momento, quis ilustrar algumas narrativas sobre o HIV e a Aids que foram mais comuns, e possivelmente mais aceitas no imaginário coletivo, durante o surgimento da infecção. Na próxima seção, pretendo retomar as narrativas a partir de múltiplas faces e entender alguns desdobramentos narrativos vinculados à infecção.

\section{3}

\section{Outras formas de narrar: as múltiplas faces de uma infecção}

As narrativas são uma fonte de insights sobre como as pessoas entendem o mundo e como elas comunicam esses entendimentos aos outros ${ }^{30}$ (BRUNER, 1990 apud WINSKELL e STEPHENSON, 2011, p. 954). As narrativas não são únicas, embora alguma prevaleçam sobre outras. Elas são múltiplas. Nessa segunda parte, eu quero trazer à discussão alguns pontos tangentes às narrativas já apresentadas na

\footnotetext{
${ }^{30}$ Tradução livre. No original: "Narratives are a source of insight into how people make sense of the world, and how they communicate those understandings to others".
} 
primeira parte desse capítulo. As metáforas e as metonímias mais associadas ao HIV e à Aids foram descritas, mas nunca serão abarcadas por completo. Aqui, apresento algumas narrativas relacionadas à moralidade, ao tempo, ao entrelaçamento do presente e do futuro, ao envelhecimento e à descoberta do HIV, à construção de comunidades, a uma percepção traumática do evento, à significação de fronteiras e doenças, em suma, a outras faces das narrativas. É fundamental compreender as ramificações dessa segunda parte do capítulo, porque as narrativas não são homogêneas (SHAFFER e ZIKMUND-FISHER, 2012, p. 4). As narrativas são polifônicas. Elas possuem diversas vozes. E é porque elas são polifônicas, que eu incluo essa segunda parte ao capítulo dois, porque compreender as narrativas sobre o HIV e sobre a Aids é mais complexo do que as narrativas hegemônicas da infecção.

Um dos pontos fundamentais na estruturação das narrativas do HIV e da Aids é a compreensão de que a moralidade se constitui como peça importante na sustentação e na perpetuação de sua inequívoca existência. Porém, não apenas a infecção do HIV se constitui como contos morais, senão a própria narrativa sobre doenças é assim constituída a partir da reinvindicação da moralidade do indivíduo e do direito de participar como membro valioso de uma sociedade (OWEN e CATALAN, 2012). As consequências discursivas da infecção, principalmente as de contato - aproximar-se e afastar-se - com pessoas vivendo com HIV, reforçam a necessidade de um indivíduo ser e manter-se moral na sociedade. Qualquer imoralidade percebida pelos olhares atentos e julgadores se desenvolve por inúmeras razões para colocar o indivíduo em um momento oposto à participação valiosa da sociedade, impulsionando-os às margens.

As narrativas do HIV e da Aids, assim como muitas narrativas de doenças, implicam duas perspectivas intrínsecas e decisivas na vida dessas pessoas: a noção de tempo e a crença na esperança (EZZY, 2000). O tempo como palpável, e decisivo na vida de pessoas infectadas pelo HIV no começo da epidemia, manifesta os afetos e as emoções em torno da esperança. Das narrativas já criadas e das imagens já reproduzidas sobre o HIV e a Aids, sabia-se que a "morte" era questão de "tempo", pelo menos sem nenhum tratamento efetivo em um horizonte próximo. Tratavamse as doenças oportunistas (TIMERMAN e MAGALHÃES, 2015). Assim como o câncer se apreendia no tempo como fator corrosivo do corpo, como destacou Sontag (1984), o início do HIV e da Aids determinou o encurtamento de trajetórias e a 
restrição da esperança. Com a esperança também restringida pelas primeiras narrativas do HIV e da Aids, principalmente na época quando a Aids representava um estado clínico irreversível, o estilista Markito quis perder a sua primeira consulta em Nova York. Quando chegou à cidade com sua mãe,

ele não foi para o hospital da Universidade de Cornell como estava programado. Teriam passado o dia passeando de limusine, no outro dia foram fazer compras e jantar com amigas da mãe. Markito só foi para o hospital porque a situação piorou e, após uma semana de passeios e compras ao lado da mãe, o estilista veio a óbito. De acordo com um amigo, José Vitor Oliva, dono da boate Gallery em São Paulo, 'Markito não foi para Nova York para se tratar, foi lá para morrer na cidade que mais amava'. (SILVA e GUEDES, 2020, p. 12)

Talvez seja muito difícil, até impossível entender quais foram as razões para que Markito não fosse imediatamente ao hospital, pois seu objetivo era de sair do Brasil e ir aos Estados Unidos em busca de tratamento. E talvez nem devêssemos entender suas razões, pois ambas se construíram em cima de seu próprio circuito de afetos, com decisões baseadas também em suas emoções, em uma construção de que o tempo lhe era vital. O tempo para viver. Segundo argumenta Ezzy (2000), as doenças com risco de vida, como foi/é o caso do HIV e da Aids, ameaçam o senso de identidade das pessoas e são vistas como certas suposições sobre o enquadramento temporal de suas vidas, por isso reforçam também que essas pessoas experimentam transformações em valores, espiritualidade e prioridades de vida (EZZY, 2000, p. 605). É em face ao HIV e à Aids, que as decisões se transformam e outras prioridades surgem. Como pesquisador, dentro das inúmeras possibilidades de compreensão dos dias aproveitados por Markito em Nova York, em oposição à imediata apresentação no hospital da Universidade de Cornell, compreendo que parte de suas manifestações afetivas e emotivas estejam ligadas à compreensão íntima da temporalidade das doenças e da orientação temporal que ele adotou diante da infecção. Assim, Ezzy (2000) enfatiza que "a existência provisória do HIV em uma pessoa soropositiva é abraçada como uma oportunidade para descobrir um novo significado e valores orientados para desfrutar do presente" 31

\footnotetext{
${ }^{31}$ Tradução livre. No original: "the provisional existence of the HIV positive person is embraced as an opportunity to dis-cover new meaning and values oriented to enjoying the present".
} 
(EZZY, 2000, p. 606). E desfrutar do presente era uma narrativa influente de uma época sem antirretrovirais.

Os tratamentos por antirretrovirais reformularam, ou tentaram suportar, o tempo das narrativas. Se antes a relação dicotômica entre viver o presente ou esperar a incerteza do futuro estava intrínseca à vida da pessoa que vive com HIV, com os antirretrovirais o futuro se tornou mais palpável para aqueles privilegiados com o acesso. A infecção do HIV e a consequência inclusão dos corpos no estado clínico da Aids é interrompida por pequenos sucessos, junto com pequenas e grandes falhas, de um tratamento de inibição viral. A narrativa da doença deixa de ser uma narrativa do caos, e a experiência da doença, embora caracterizada como sem sentido, vazia e desprovida de propósito, atém-se a uma clara esperança para o futuro (EZZY, 2000, p. 606). Mas embora os efeitos dos tratamentos tenham eliminado a morte por decorrência da infecção, eles não foram capazes de eliminar narrativas metonímicas que ainda associam o HIV e a Aids à morte.

Embora não estivesse explicitamente presente através de menções de temporalidade - passado, presente, futuro - houve uma mudança nas narrativas sobre o HIV e a Aids, especialmente em relação ao futuro (EZZY, 2000). Mas, me pergunto, o que não nos diz mais sobre nossos futuros do que a morte? É uma realidade. O HIV e a Aids adiantaram esse processo no começo da epidemia. Houve a reinvenção do futuro, ao menos em relação à sua espera, para os pacientes que tiveram o encontro com o vírus antes de fórmulas eficazes de tratamento, mas reconhecendo que esse encontro não foi totalmente extinguido. Até 2019, ao menos $67 \%[54-79 \%]^{32}$ de todas as pessoas vivendo com HIV tiveram acesso ao tratamento. Ainda existe ao menos 33\% [46\%-21\%] de pessoas sem acesso à tratamento, seja por desconhecimento do status sorológico, seja por questões financeiras e sanitárias públicas, seja por fatores estruturais impeditivos ao tratamento.

Em 1996, Davies (1996) já desprendia em seus pensamentos a perspectiva de futuro de uma pessoa com HIV, alegando-lhe a liberdade sobre a responsabilidade "de ter que construir um plano significativo de longo prazo para sua vida e, subsequentemente, ser capaz de desfrutar o presente pelo que ele é, ao invés de

${ }^{32}$ UNAIDS. Estatísticas, 2020. Disponível em: <https://unaids.org.br/estatisticas/>. Acesso em: 30 mar. 2021. 
deliberar sobre suas implicações ou possibilidades para o futuro"33 (DAVIES, 1996, p. 567 apud EZZY, 2000, p. 608).

Embora o HIV e a Aids tenha sido uma infecção enxergada principalmente em pessoas mais jovens, a proporcionalidade de pessoas vivendo com HIV entre 50 e 78 anos tornou-se alta (OWEN e CATALAN, 2012, p. 59). Esse fato desestabiliza paradigmas construídos no começo narrativo da infecção, proporcionando, agora, novos públicos que se viram diante do vírus. A surpresa por trás desse público é, em primeiro lugar, o enfrentamento de que pessoas mais maduras estariam mais propícias à prevenção por conta da ideia de maturidade. Entretanto, deve-se sempre compreender que para contrair o HIV a pessoa precisa se envolver em práticas vulneráveis. $\mathrm{O}$ choque apresentado pelos autores, percebido em relação a essa faixa etária, é ocasionado por ser contraposto às narrativas criadas em torno do vírus, vislumbrada e propagada através de rostos jovens masculinos. Além disso, dessa faixa etária visualizam-se e projetam-se apenas doenças relacionadas ao envelhecimento, como doença arterial coronariana, dislipidemia, síndrome metabólica, diabetes, osteoporose e demência, e que, por causa do HIV e da Aids, podem se desenvolver mais cedo, além de notar prejuízos cognitivos e alterações metabólicas e hormonais (MYERS, 2009 apud OWEN e CATALAN, 2012).

Ao viver com HIV nessa faixa etária, a narrativa do HIV e da Aids se modula em narrativas já direcionadas ao processo de envelhecimento. Por um lado, observam-se certas atribuições às pessoas mais velhas, como maior sabedoria, paciência e contentamento, enquanto por outro lado, as desvantagens se mostram pela deterioração física, isolamento social e falta de simpatia dos outros (RAVEIS e KARUS, 1998 apud OWEN e CATALAN, 2012). Assim, as narrativas do HIV e da Aids se constroem sobre essas questões observadas nas pessoas mais velhas e ainda se ressaltam como uma vulnerabilidade dupla do preconceito etário e do estigma do HIV que produz experiências de discriminação, estereotipagem, rejeição e isolamento social (OWEN e CATALAN, 2012, p. 60).

O estranhamento afetivo e emotivo em relação às pessoas mais velhas vivendo com HIV, em um primeiro momento, deve-se à própria construção narrativa da infecção, considerando e narrando seus personagens principais, mais

\footnotetext{
${ }^{33}$ Tradução livre. No original: "the responsibility of having to construct a meaningful long-term plan for his/her life and, subsequently, is able to enjoy the present for what it is, rather than deliberating upon its implications or possibilities for the future".
} 
considerados antagonistas do que protagonistas, como um público mais jovem e dotado do combo desviante das normas sociais. Assim, Timerman e Magalhães (2015) também ilustram parte das narrativas da infecção deslocadas desses antagonistas e dirigidas às pessoas mais velhas. Em "onde já se viu falar para uma senhora de idade que ela tem HIV?"34, a história de Marieta, nome fictício, de 86 anos, professora de piano, é contada desde a descoberta do HIV em sua vida aos 66 anos de idade. Nessa época, os exames apresentavam uma alta quantidade de vírus no organismo, indicando a possibilidade de estar infectada há vários anos. E por diferenciar falsos grupos de riscos, em vez de práticas vulneráveis, Marieta relatou como foi sua manifestação afetiva durante a descoberta:

\begin{abstract}
Quando recebi a notícia, parece que um prédio veio abaixo na minha cabeça. Nessa época, ninguém falava que uma pessoa com a minha idade, casada, podia ter Aids. Um dos meus filhos queria 'matar' o médico por ter me dado a notícia de supetão. 'Onde já se viu falar para uma senhora de idade que ela tem HIV?', disse, indignado, na época. (TIMERMAN e MAGALHÃES, 2015, p. 30)
\end{abstract}

Na relação de seu corpo em relação ao corpo alheio (AHMED, 2014), Marieta conta que suas amigas sabem que ela vive com HIV e em nada mudou a sua relação. Inclusive, a aproximação exclusiva gerada pelos segredos compartilhados em torno do HIV e da Aids proporcionou a confissão de que uma de suas amigas possuiu um irmão vivendo com o HIV. Possuiu. Infelizmente, seu irmão não suportou as narrativas dilaceradoras sobre a infecção e se suicidou. Talvez seja essa a razão de uma maior aproximação entre as duas amigas: "quando eu contei que também era portadora do HIV, ela se apavorou. Não me largava um minuto. Queria cuidar de mim" (TIMERMAN e MAGALHÃES, 2015, p. 31).

O HIV e a Aids são uma poderosa condição para definir identidades e comunidades (SQUIRE, 1999). De um dia para o outro, a pessoa vivendo com HIV se insere forçosamente em circuitos de afetos incompreensíveis até o momento. As identidades se aglutinam, dialogam, compartilham experiências e previnem os impactos afetivos causados pelas persistentes narrativas. Explica-se, logo de cara, com as mãos ainda segurando o exame, em que a palavra REAGENTE induz os primeiros afetos e emoções, que HIV não é morte. É uma infecção crônica. Assim

\footnotetext{
${ }^{34}$ Nome do quinto capítulo da primeira parte do livro.
} 
como diabetes, hipertensão, osteoporose, mal de Parkinson, Alzheimer, Asma e uma lista sucessiva de doenças crônicas, em que o HIV às vezes nem está inserido. Porém, um dos desafios de classificar o HIV como uma infecção crônica é mostrar à sociedade que práticas preventivas devem ser tomadas. Não se trata de comporse como uma infecção tratável que se deve deixar a prevenção para momentos ocasionais. A prevenção é constante. O HIV está frequentemente associado à produção de novas formas de política e de subjetividade, de estigmatização e de marginalização (SQUIRE, 1999). Descobrir-se que se vive com HIV é uma descoberta significativa, que expõe o indivíduo a uma nova realidade afetiva e emocional (STEVENS e TIGHE DOEER, 1997, p. 523).

O HIV e a Aids unem e influenciam a formação de comunidades porque essa força provinda da união dessas pessoas é necessária para a formação de novos ativistas do HIV e da Aids, para contribuir e divulgar campanhas por melhor educação e tratamento, lutar contra políticas discriminatórias e representações negativas e, principalmente, ressignificar as narrativas construídas sobre a infecção (SQUIRE, 1999). Pessoas vivendo com HIV tornaram-se emblemas de políticas e subjetividades ativas e criativas (SQUIRE, 1999), unindo afetos para representar suas próprias realidades e aproximando-se, narrativamente, de uma sociedade que sempre as distanciou de si.

Um dos exemplos mais lembrados para falar das primeiras articulações comunitárias para responder às narrativas corrosivas do HIV e da Aids foi o movimento ACT-UP, um movimento de ativismo queer de forte atuação sobre o tema nos anos 1980-1990 (SQUIRE, 1999, p. 110). O ativismo queer narrado por Squire (1999) representa a ligação do que a Ahmed (2014) descreve como política do luto, envolvendo a questão de quais perdas são consideradas graves. De fato, “o ativismo em torno da AIDS produziu obras de luto coletivo, que buscaram fazer apresentar a perda de vidas queer dentro da cultura pública”35 (AHMED, 2014, p. 156). Ressaltar que o ativismo queer, trabalhado pelos autores, em torno das questões do HIV e da Aids representou uma luta política de assumir lugares e representar as falas dos que se foram é ampliar o circuito dos afetos e das emoções comuns ao luto na sociedade. O luto - afetivo, emotivo, também político - é impulso para novas narrativas, para novos significados, para novas barreiras que

\footnotetext{
${ }^{35}$ Tradução livre. No original: "The activism around AIDS produced works of collective mourning,
} which sought to make present the loss of queer lives within public culture". 
tentam, mesmo desgastando emocionalmente seus bravos e necessários apoiadores, evitar que as narrativas do HIV e da Aids se tornem permanentes.

Não são números, estatísticas apenas. Cada vida é pintada a fim de transformar um número em um ser, aquele que foi perdido para alguém (AHMED, 2014). Mas essas perdas às vezes não são apenas individuais. Algumas perdas, mais do que outras, vieram para encorpar a perda coletiva. Pessoas que morreram em decorrências das complicações do estado clínico da Aids foram as razões para o luto queer coletivo e viraram símbolos de reinvindicação e de luta para conseguir respostas e direitos à saúde.

E mesmo com as manifestações queer nas ruas, e as constantes lutas para reformular as narrativas expostas e perseguidoras do HIV e da Aids, é preciso compreender que o HIV não significa o mesmo para todos (SQUIRE, 1999). Havia os que morriam, havia os que lutavam, havia os que agradeciam pela erradicação desse mal e de seus corpos. Mas já nessa época, havia principalmente histórias de aprender e de conviver com a existência do HIV. Eram histórias e narrativas contadas por pessoas vivendo com HIV e pessoas cercadas em seus próprios circuitos afetivos de outras pessoas vivendo com HIV. As histórias tornaram-se instâncias significativas de reconsideração reflexiva e até mesmo geraram ressignificação da própria subjetividade, seja a partir de uma subjetividade do sujeito com ele mesmo ou do sujeito com a comunidade (BECK 1992; GIDDENS, 1991; SHILLING, 1992 apud SQUIRE, 1999). Já se compreendia que o HIV não era uma infecção isolada no sujeito, senão uma infecção compreendida na comunidade, para o bem e para o mal.

Ver com os mesmos olhos de hoje para um evento da década de 1980 impõe lacunas impreenchíveis se analisarmos a situação do HIV como epidemia nesses dois contextos. De uma realidade em que viver com HIV é baseado em uma série de tratamentos precisos e eficazes para uma realidade em que a infecção ainda detinha a narrativa de enigma percebe-se o tamanho desses dois tempos. Para Stevens e Tighe Doeer (1997), que inserem seus estudos em uma realidade diferente da minha, eles descreveram que independente das circunstâncias guiadas à realização do teste de anticorpos do HIV, a descoberta do vírus em si foi um evento traumático, evidenciado pelas histórias contadas dos participantes de suas pesquisas que relataram sentimentos de ameaça e desamparo (STEVENS e TIGHE DOEER, 1997). A narrativa da descoberta tornava-se uma narrativa de pesar, de 
manifestação instantânea de paixões tristes: "Lamento dizer-lhe, mas o seu teste deu positivo. Você tem HIV"36 (STEVENS e TIGHE DOEER, 1997, p. 527).

A partir dos relatos desse encontro, a manifestação de afetos e emoções capazes de diminuir a capacidade de agir diante da situação se evidencia pelas manifestações narrativas já presentes em torno do HIV e da AIDS. Algumas mulheres entrevistadas por Stevens e Tighe Doeer (1997) descreveram suas emoções: "Ele me contou que eu estava infectada com o vírus do HIV. Eu pensei que ele tinha me sentenciado à morte"; "Eu me senti morta imediatamente"; "tudo o que eu consegui pensar foi que eu vou morrer amanhã. Eu surtei" ${ }^{37}$ (STEVENS e TIGHE DOEER, 1997, p. 527). Outros extratos desses momentos de manifestação vocálica sobre os afetos e as emoções presentes em suas existências refletiram, para algumas, uma sombra da morte espreitando ameaçadoramente a partir daquele momento e grandes momentos de ansiedade:

Essa coisa já me matou. Isso me deu uma sentença. Eu estou existindo agora, isto é tudo"; "já se passaram seis meses e não sei quando vai acontecer, a doença e a morte. Eu tenho isso na minha cabeça o tempo todo"; "Achei que ia cair morta a qualquer momento. Eu vivi assim por alguns anos"; "Foi horrível porque pensei que ia morrer. Eu não queria morrer. Eu tive um tempo difícil. Usei muito [drogas injetáveis] depois disso. Fisicamente, fiquei muito doente. Eu sabia que eu não duraria muito. Está meio escuro agora porque já se passaram seis anos. Eventualmente ficou melhor. Acho que comecei a perceber que as drogas iam me matar e não o HIV. (STEVENS e TIGHE DOEER, 1997, p. 527) 38

A absorção da autoimagem como poluente, assim como explanado metaforicamente por Sontag (1989) com as doenças infecciosas causadas por fluídos humanos, é empregada nas narrativas dessas personagens ao descobrir-se

\footnotetext{
36 Tradução livre. No original: "I am sorry to tell you, but your teste came back positive. You have $H I V^{\prime \prime}$.

37 Tradução livre. No original: "He told me I was infected with the HIV virus. I thought he had sentenced me to die"; "I immediately felt death"; "All I could think of is I am going to die tomorrow. I freaked out".

${ }^{38}$ Tradução livre. No original: "This thing has already killed me. It gave me a sentence. I am existing now, that is all; "It has been six months and I don't know when it is going to happen, the sickness and death. I have this over my head all the time; "I thought I was going to drop dead at any moment. I lived like that for a couple of years"; It was horrible because I thought I was going to die. I didn't want to die. I had a hard time. I used [injection drugs] a lot after that. Physically I got really ill. I knew I wouldn't last long. It is kind of dim now because it has been six years. Eventually it got better. I think I started to realize the drugs were going to kill me; HIV wasn't."
} 
com o HIV. As imagens sobre si mudaram repentinamente de "pessoas" para “poluentes", capazes de contaminar e matar:

\begin{abstract}
por alguns anos, o tempo todo em que eu pensava se eu respirasse em você, você se infectaria. Em meu coração, eu sabia que, se fizesse sexo com alguém, estaria cometendo um ato de assassinato. Quando eu descobri, meu bebê era tudo para mim. Meu bebê tinha Aids. Eu pensava que ele ia morrer. E se ele morrer? Oh Deus, eu sou uma assassina. O que eu fiz? ${ }^{39}$ (STEVENS e TIGHE DOEER, 1997, p. 527)
\end{abstract}

Sobre as mulheres com HIV, apresentam-se diferentes narrativas sobre a infecção. Se por um lado, a mulher é vista como uma vítima inocente de seus parceiros sexuais masculinos quando contraem o vírus através de relações sexuais desprotegidas, por outro lado, quando ela engravida, ela é transformada em culpada por transmitir o HIV ao seu filho através da transmissão vertical (TREICHLER, 1999 apud RUIZ, 2002, p. 39).

As narrativas sobre o HIV e a Aids são sobre uma interrupção de qualquer normalidade da vida da pessoa que descobre estar vivendo com HIV As próprias histórias e os próprios objetivos no mundo se reformulam após essa descoberta. Como se percebe aqui, através das vozes dessas mulheres, o momento de reclusão de seu corpo é intrínseco aos saberes narrativos do HIV e da Aids. Conhece-se todo o processo por trás do desenvolvimento do HIV muito antes de o corpo ter contato com o vírus. Parte da conclusão desse estudo sobre as narrativas dessas mulheres nesse momento é a própria afirmação e assimilação da descoberta como evento traumático, porque a partir desse instante cada uma das mulheres, e eu diria de qualquer pessoa que vive esse fato, impõe limites em seus próprios corpos, gera novos olhares a partir de si, provoca novas interpretações sobre suas relações sociais e com as suas relações com o mundo (AHMED, 2014; STEVENS e TIGHE DOEER, 1997). E esses novos limites, olhares e interpretações não vieram do nada, senão foram construídos junto com as narrativas do HIV e da Aids e provocaram novas assimilações. Pois, embora as narrativas sejam descritas, enumeradas e ilustradas, elas são sempre interpretadas de forma única pelo indivíduo, que apresenta ou não as suas ações diante dessa nova realidade que o circunda. Dessa

\footnotetext{
${ }^{39}$ Tradução livre. No original: "For a couple years, all the time I was thinking if I breathe on you, you are going to get infected. In my heart I knew that if I had sex with anyone, I was committing an act of murder. When I found out, my main thing was by baby. My baby had AIDS. I was thinking, he is going to die. What if he dies? Oh God, I am a murderer. What have I done?"
} 
nova realidade, os afetos e as emoções ganharam alguns nomes: "entre suas reações estavam choque, medo, angústia e suicídio. A maioria experimentou uma cominação dessas intensas repercussões do trauma"40 (STEVENS e TIGHE DOEER, 1997, p. 532).

A capacidade de agir a partir da experiência do choque em relação a essa descoberta foi influenciada porque o choque provoca perturbações súbitas e violentas em pessoas pegas desavisadas e desprotegidas ao ouvirem a notícias, cegando-as, deixando-as desorientadas (STEVENS e TIGHE DOEER, 1997, p. 531). Esse despreparo para ouvir uma notícia como essa também se funda na seletividade narrativa sobre o HIV e sobre a Aids: "eu não sabia nada sobre pegar Aids. Homens gays, pessoas vindas do Haiti estavam pegando isso. Eu não escutei que mulheres estavam pegando isso. Eu estava tão confusa. O que você está me dizendo?"41 (STEVENS e TIGHE DOEER, 1997, p. 532).

Abordar o HIV e a AIDS como evento de saúde acontecendo e se expandindo em uma região não significa, necessariamente, um recorte narrativo desse momento. As narrativas aparecem a partir da constante reprodução de assimilações específicas com a infecção, através de metáforas e metonímias, por exemplo, em uma escala ampla, podendo partir de um difusor midiático. Heller (2015) percebeu que a Aids e o HIV espalhavam rumores em comunidades mais específicas. Assim, o HIV e a Aids, para além da construção narrativa, apresentam uma face de murmúrios, de rumores, de incertezas muitas incertas, mas de forte convicção ao que se ouve.

Parte desses rumores eram investidos de crenças conspiratórias, mais do que incertezas apresentadas. Ressalto que, embora seja provável que esses rumores tenham sido semelhantes em outros espaços e em outros tempos, o estudo apresentado por Heller (2015) faz um recorte sobre os Estados Unidos, enfatizando, principalmente, os rumores circulatórios na comunidade afro-americana e que grande parte desses rumores apareceram junto com o HIV e a Aids. O aparecimento desses rumores está vinculado ao próprio circuito de afetos dessa sociedade, porque se conectaram com a escassez de informações confiáveis nas primeiras notícias

\footnotetext{
${ }^{40}$ Tradução livre. No original: "Among their reactions were shock, fear, anguish, and suicidality. Most experienced a combination of these intense repercussions from the trauma".

${ }^{41}$ Tradução livre. No original: "I didn't know anything about getting AIDS. Gay males, people from Haiti were getting it. I didn't hear that women were getting it. I was so confused. What are you telling me?"
} 
sobre o vírus além de se conjugar com os altos níveis de ansiedade social provindo da falta de informação (HELLER, 2015, p. 43). A ansiedade social, como manifestação de ansiedade na sociedade a partir de determinados objetos que se apresentam para nós, como foi o caso do surgimento do HIV e da Aids, conecta-se com a capacidade de agir diante da situação. E agir nesse caso significou acolher os rumores ou rejeitá-los. Por suposto, os rumores foram muito bem acolhidos, pois se construíram dentro de suas comunidades afetivas, expressando o que Heller (2015) definiu como redes de confiança e conhecimento. As redes de confiança e conhecimento estão limitadas "aos mesmos elementos de estratificação social que constituem identidades e subgrupos raciais e étnico; pessoas que circulam histórias para outras que conhecem e confiam e apenas recontam histórias com significado ou ressonância"42 (HELLER, 2015, p. 43). Assim, os rumores proliferam em toda a sociedade dos Estados Unidos, servindo de base para narrativas persistentes:

apenas gays podem pegar Aids; você pode pegá-la de uma maçaneta, um assento de vaso sanitário ou uma piscina; insetos voadores podem transmiti-la; mulheres estão enganando homens em fazer sexo com eles para que eles possam dar a elas Aids; Aids foi desenvolvida pela Agência Central de Inteligência (CIA) para matar afro-americanos e gays; não é causado por um vírus de forma nenhuma. ${ }^{43}$ (HELLER, 2015, p. 43)

Acreditava-se que abraços e beijos eram proibidos, que dessa atitude afetiva em relação ao outro se poderia ter HIV. Mas esses rumores ainda estão presentes. Não se desfizeram no ar com as sucessivas descobertas em torno do HIV e a Aids. Abri o Google e digitei: "pode pegar HIV..."; e o navegador me sugeriu algumas situações já pesquisadas por outros usuários: "pelo beijo, pela boca, pela saliva, pelo olho, na piscina”. São dúvidas ainda frequentes e não extintas com novos saberes. Às vezes, esses saberes nunca foram difundidos de forma eficaz na sociedade e, assim como outras dúvidas, recorremos à internet para nos informar ou nos desinformar. A internet é o grande palco das conspirações. Mas, de forma

\footnotetext{
42 Tradução livre. No original: "the trust and knowledge networks that support rumors are typically bound by the same elements of social stratification that constitute racial and ethnic identities and subgroups; people circulate stories to people they know and trust, and only retell stories with meaning or resonance".

${ }^{43}$ Tradução livre. No original: "only gay people can get AIDS; you can catch it from a doorknob, a toilet seat, or a swimming pool; flying insects can transmit it; women are tricking men into having sex with them so they can give them AIDS; AIDS was developed by the Central Intelligence Agency (CIA) to kill off African Americans and gays; it's not caused by a virus at all".
} 
geral, Heller (2015) relata que conforme as informações sobre o HIV e a Aids se tornavam sólidas, as fontes de notícias oficiais conseguiram apaziguar a maioria dos rumores do HIV e da Aids (HELLER, 2015, p. 43). Entretanto, "dentro da comunidade afro-americana, os rumores específicos continuavam a persistir, principalmente os rumores que entendem o HIV e a Aids como uma conspiração genocida do governo contra os afro-americanos" (HELLER, 2015, p. 43).

O desenvolvimento do rumor conspiratório de que o HIV servia como arma do governo estadunidense para eliminar a comunidade afro-americana não estava baseado apenas em conspiração. Heller (2015) relata que os homens negros obtiveram uma das maiores taxas de contágio, além dos casos, ainda hoje muito visíveis, de violência policial contra a população negra. Além disso, a memória coletiva sobre o racismo e os abusos discriminatórios na sociedade dos Estados Unidos servem como boa estrutura para rumores que unem o passado histórico de uma sociedade com os desafios do presente (HELLER, 2015). Os rumores são apresentados não apenas como uma crença significativa para as comunidades, mas também como convicções políticas e identitárias. Para desmantelar os rumores, é necessário o conhecimento de como eles se apresentam em formas discursivas para compreender a melhor maneira de responder, articular e interferir nos esforços de saúde pública (HELLER, 2015, p. 44). Mas ainda, os rumores podem servir para outros fins, como o caso do humorista Dave Chappelle que utiliza em sua rotina humorística e enfatiza uma versão irreal do verdadeiro surgimento do HIV, contando que a explicação científica viria do sexo entre africanos e macacos (HELLER, 2015, p. 45). Além de adicionar ao seu repertório sátiras à Freddie Mercury $^{44}$ (LEWIS, 2020).

A culpabilização sobre o estrangeiro, sempre visto como responsável por trazer doenças e infecções, já foi discutida por Sontag $(1984$; 1989) e mostrada nessa dissertação. Entretanto, o que não foi apresentado dessa face sobre o estrangeiro é a sua transformação em alienígena, ou seja, um ser não-humano ao qual a culpa das doenças e das infecções é lançada. Um caso apresentado por Ruiz (2002) demonstra muito bem a particularidade - ou a universalidade - de uma

\footnotetext{
${ }^{44}$ LEWIS, Isobel. 'Not funny in the 1980s, not funny now': Dave Chappelle criticized for making Freddie Mercury joke on SNL. Independent, 2020. Disponível em: <https://www.independent.co.uk/arts-entertainment/tv/ news/dave-chappelle-snl-freddie-mercuryaids-trump-coronavirus-b1719689.html>. Acesso em: 22 abr. 2021.
} 
mulher não-estadunidense e vivendo com Aids encontrada doente na região fronteiriça entre Estados Unidos e México. Em resumo, durante uma Medline, um relatório de casos específicos apresentados durante a Conferência Nacional sobre Mulheres e HIV em 1997, o seguinte caso foi apresentado:

uma mulher hispânica de 37 anos, indocumentada, da Guatemala, apresentou-se com AIDS (CD4, 50). Ela perdeu o seguro de saúde porque estava muito doente para trabalhar. Ela falava espanhol e não tinha rede de apoio fora da prática médica. Ela desenvolveu um câncer cervical invasivo e MAI (Mycobacterium avium intracellulare). Alegadamente, ela foi estuprada durante a travessia da fronteira para entrar nos Estados Unidos. ${ }^{45}$ (RUIZ, 2002, p. 37)

Ressalta-se que essa infecção (MAI) apresentada na mulher relatada "é uma doença infecciosa sistêmica que pode ocorrer em pessoas em estágios avançados de AIDS e, embora não cause a morte, é considerada um prenúncio da morte, pois se manifesta quando as células CD4, importantes células do sistema imunológico, são praticamente zero"46 (RUIZ, 2002, p. 37). Em suma, o que Ruiz (2002) nos mostra é a relação burocrática da existência do estrangeiro latino nos Estados Unidos. Já é de conhecimento metafórico que essas pessoas sem documentos são vistas como ilegal aliens - caracterização não apenas do alienígena, alheio às terras de onde se fala, mas principalmente da exterioridade do outro, incapaz de ser reconhecido como detentor de direitos onde se fala - e enfrentam barreiras, mais do que linguísticas, no acesso à saúde. O retrato dessa mulher mostra a realidade de muitos outros imigrantes sem documento que, durante a epidemia de HIV, viram-se distantes das instituições sanitárias e mais próximos de tratamentos alternativos e culturais, buscando curandeiros ou curador tradicional para lidar com a infecção (RUIZ, 2002). Assim, Ruiz (2002) indaga-se o porquê de essa mulher chegar só no fim da sua vida à procura do sistema de saúde e reflete que esse caso se deve principalmente por duas questões: tratava-se de uma mulher sem documentos,

\footnotetext{
${ }^{45}$ Tradução livre. No original: "A Medline abstract from the 1997 National Conference on Women and HIV presents the following case: An undocumented 37 year old Hispanic Woman from Guatemala presented with AIDS $(C D 4,50)$. She lost her health insurance because she was too sick to work. She was Spanish Speaking only and had no support network outside of the medical practice. She developed invasive cervical CA [cancer] and MAI [Mycobacterium avium intracellulare]. Reportedly, she was raped while crossing the border to enter the U.S"

${ }^{46}$ Tradução livre. No original: "MAI is a systemic infectious disease that may occur in people with advanced stages of AIDS and, although it does not cause death, it is considered a harbinger of death since it manifests when CD4 cells, important immune cells, are virtually zero".
} 
metaforizada em um alienígena ilegal, enfrentando a discriminação e a exclusão; e que a discriminação não se restringia apenas à sua existência, senão à inviabilidade de acessar o sistema de saúde. Por mais que não seja a crença de muitos, ou muitos não considerem relevante estudar fronteiras e o HIV e a Aids, é extremamente relevante aprisionar para a vida o que Ruiz (2002) nos enfatiza: "como muitos críticos culturais mostraram, as fronteiras moldam as doenças, incluindo o HIV e a Aids" $" 47$ (RUIZ, 2002, p. 38). As fronteiras definem nas pessoas que transitam ou que vivem a região fronteiriça questões maiores do que a mobilidade. Elas são capazes de definir o acesso à saúde, o acesso à vida. Não se cruzam fronteiras apenas por lazer, elas estão infiltradas na vida das pessoas que constroem o internacional e na vida de muitas pessoas que vivem com HIV. As fronteiras nacionais também induzem a outro dinâmica: são usadas para estabelecer as origens da culpa pelas doenças, além de consolidar identidades nacionais e culturais (SONTAG, 1989; RUIZ, 2002).

Mas o que realmente significa dizer que o HIV e a Aids não possuem fronteira? Ruiz (2002) elenca uma série de questões sobre as fronteiras e a infecção:

\begin{abstract}
isso significa que a Aids é impulsionada por forças globais que transcendem as fronteiras nacionais? Contesta a noção de fronteiras como barreiras às doenças? Também contesta as fronteiras raciais, étnicas e nacionais? É um aviso para aqueles que ainda podem pensar que a Aids é uma 'doença gay', uma 'doença dos brancos' ou uma 'doença dos gringos'? ${ }^{48}$ (RUIZ, 2002, p. 39)
\end{abstract}

Mas a sua argumentação à articulação entre fronteiras e o HIV e a Aids é que as narrativas das fronteiras derivam da ideia de que os imigrantes latinos são e estão doentes, e que a fertilidade do terceiro mundo e a reprodução constitui uma ameaça aos Estados Unidos (RUIZ, 2002, p. 40). Assim, o estereótipo do alienígena ilegal torna-se uma metáfora poderosa na ciência e na medicina, elencando e reforçando uma aliança sugerida entre as autoridades médicas e científicas e o Estado Nacional

\footnotetext{
${ }^{47}$ Tradução livre. No original: "As many cultural critics have shown, borders shape disease, including HIV/AIDS".

${ }^{48}$ Tradução livre. No original: "Does it mean simply that AIDS is a global problem? Does it mean AIDS is driven by global forces that transcend national boundaries? Does it contest the notion of borders as barriers to disease? Does it also contest racial, ethnic, and national borders? Is it a warning to those who may still think AIDS is a "gay disease," a "white disease," or a "gringo disease"?
} 
(RUIZ, 2002, p. 49). As fronteiras e as infecções representam um assunto fulcral, embora não da maneira como é retratado pela mídia em todas as suas narrativas (RUIZ, 2002; BARATA, 2006).

Como já descrito por Passos e Barros (2009), uma das maneiras mais eficazes de contornar as narrativas do HIV e da Aids é abordar a infecção a partir da descrição de práticas vulneráveis e não da delimitação de grupos que partilhariam uma identidade construída comum. É sempre imprescindível abordar o HIV e a Aids para além das narrativas construídas dominantes. Um papel importante nessa luta de prevenção do HIV e da Aids é, ademais de uma eficaz participação das mídias, a educação coesa e coerente com práticas científicas e éticas. Sabe-se que a construção do HIV e da Aids é majoritariamente influenciada por discursos dominantes de sexualidade e de doenças, ou seja, há concepções sobre as infecções sexuais baseadas na moralização dos corpos (BAXEN, 2008). O HIV e a Aids não devem ser vistos como caracterização de corpos. Por mais que, em relação a esses, exista a aproximação ou a repulsa emocional como descreveu Ahmed (2014), o corpo seja marcado socialmente. É-lhe atribuído gênero. É-lhe sexualizado. É-lhe racializado. E todas essas características dos corpos, incluindo dos corpos de pessoas que vivem com HIV, moldam a posição narrativa do indivíduo no mundo. Moldam, influenciam ou impulsionam a posição narrativa. Mas também o corpo pode ter sua capacidade de agir diminuída em função da produção de afetos tristes pelas narrativas circulantes.

De todas as partes da dissertação que construí até aqui, existe uma em especial que me debrucei durante vários meses. Nenhuma outra parte me fez refletir mais quanto à fala de Thandi, nome fictício, uma professora negra de Mpumalanga, na África do Sul, que contribui com a educação como estratégia-chave de prevenção ao HIV e à Aids. Ela ensina sobre saúde sexual e, por estar em uma comunidade de características poligâmicas, vive também em um relacionamento poligâmico. E por mais que ela saiba a necessidade e a primordialidade dos preservativos na preservação de ISTs, além de método contraceptivo, ela citou "ansiedade" em abordar o assunto de preservativos com seu marido. Segundo ela, "isso levantaria a suspeita de seu marido quanto à sua fidelidade, mesmo estando ansiosa para discutir a proteção, tinha medo de quais consequências isso teria e, por isso, permaneceu 
em silêncio"49 (BAXEN, 2008, p. 316). Minhas reflexões surgiram depois que a Thandi ficou em silêncio. Como pesquisador, milhares de perguntas surgiram diante de mim e meus afetos manifestaram-se mais para a incompreensão de sua atitude do que para o verdadeiro significado afetivo daquele ato. Se ela sabia e conhecia a efetividade dos preservativos, por que não aplicava esses conhecimentos em sua vida? Mas não é por sabermos como a prevenção do HIV e da Aids funciona, que estaremos sempre dispostos a nos prevenir, porque a prevenção nem sempre é uma atitude ou uma responsabilidade unilateral. Existem afetos e emoções manifestadas sobre nossos corpos que podem nos mover a decisões totalmente contrárias aos nossos conhecimentos racionais e científicos. E muitas mulheres contraíram o HIV a partir desse ato de colocar a sua própria fidelidade em dúvida e da construção de confiança diante de seus maridos infiéis (TIMERMAN e MAGALHÃES, 2015).

Ainda refletindo sobre a posição narrativa dessa professora, é importante reforçar três pontos importantes. O primeiro é que não só por sabermos, ou termos a noção, de que a prevenção do HIV ocorre também a partir do uso correto de preservativos que estaremos livres a usá-los sempre. Existe, como Thandi ressaltou, relações de poder desproporcionais durante as relações sexuais. E essas desproporcionalidades nos levam ao segundo ponto: o uso de preservativos, nesse contexto e em contextos semelhantes, para além de sua função de prevenção sexual e de gravidez, representa um símbolo de infidelidade em relação aos parceiros sexuais. No caso de Thandi, o uso de preservativos representou a suspeita de infidelidade sobre Thandi, ao mesmo tempo que a fidelidade em relação ao seu parceiro lhe era questionada. A manifestação emocional da fidelidade, sentir-se fiel a sentimentos e afetos genuínos e a compromissos estabelecidos, provoca o rompimento racional sobre o uso de preservativos de uma das partes. O terceiro ponto é compreender a manifestação afetiva em torno da fidelidade, além da desproporcionalidade de tomada de decisão sobre o uso de preservativo durante o ato sexual entre um homem e uma mulher, por exemplo, não excluindo a existência dessa desproporcionalidade também entre casais LGBTQIA+, questiona o desafio da educação sexual e da prevenção do HIV e da Aids em casais heterossexuais, cuja infecção mostra-se crescente em contraste a casais homossexuais.

${ }^{49}$ Tradução livre. No original: "She was eager to discuss protection but was afraid of the consequences this would have and, as such, remained silent". 
Existe uma relação que nem sempre é muito nítida quando se trabalha com as narrativas. Pois estudar e tecer narrativas possuem múltiplas finalidades de acordo com os afetos e as emoções do pesquisador. Porém, essa relação está fortemente conectada com o trabalho de Passos e Barros (2009), que é utilizar as narrativas existentes, presentes e circulantes na sociedade como elementos influenciadores de direcionamento e de tomada de decisão sobre a prevenção de infecção e a melhor maneira de explicar e disponibilizar os tratamentos (SHAFFER e ZIKMUNDFISHER, 2012, p. 4-5).

As narrativas podem ser usadas para fornecer informações sobre diversas questões sanitárias, além de impulsionar reflexões que podem se tornar informações técnicas sobre doenças ou tratamentos, tornando-se muito mais eficazes na comunicação de informações básicas sobre cuidados de saúde, do que abordagens que desconsiderem as narrativas (SHAFFER e ZIKMUND-FISHER, 2012). Em partes, apreender elementos estruturais das narrativas e transformá-los em políticas públicas de saúde através de abordagens específicas para casos semelhantes é fundamental para impulsionar prevenção e tratamento do HIV e da Aids, por exemplo, como de outras doenças e infecções que impulsionam outras narrativas.

Para além dos objetivos de tecer as narrativas e evidenciá-las como mobilizadoras de afetos e emoções das pessoas que narraram e que são narradas, mostrando também que a partir delas é possível direcionar medidas amplas de prevenção e tratamento das infecções e das doenças presentes nas narrativas, é importante ilustrar o principal movimento impulsionado por afetos e emoções circulantes de um circuito social específico que é o movimento de contranarrativa. As narrativas apresentadas aqui também servem de impulso para desmistificá-las, para questioná-las, para refleti-las como inquietações reais e presentes quando se debate HIV e Aids. Ou que já foram presentes em outros momentos e foram questionadas por movimentos sociais, impulsionando novas contranarrativas sobre o HIV e sobre a Aids. Além da abordagem sanitária descrita por Passos e Barros (2009), no que tange à reflexão e à ação em torno do contingenciamento epidêmico, as narrativas criadas desse movimento também se tornaram contranarrativas vivas dispostas a apaziguar os efeitos dilaceradores de narrativas corrosivas. 


\section{4}

\section{Conclusão}

Explorar as narrativas do HIV e da Aids a partir de construções metafóricas e metonímicas não foi fácil. As narrativas manifestam sobre nós, ao menos sobre mim manifestaram, afetos e emoções que podem nos paralisar. Por vários dias estive reflexivo sobre as narrativas que descobria. E a partir desse momento de reflexão, também influenciado por discursos políticos, entendi qual era o papel das contranarrativas na sociedade.

As narrativas transnacionais nos mostraram como a epidemia de HIV foi construída. Formou-se também na estrutura de ficção: possuíamos lugares, conflitos, personagens divididos entre vilões e mocinhos. A diferença é que essa ficção não possui um fim definido. Embora todas as forças possíveis desenhassem as pessoas que vivem com HIV para fora dos círculos de convivência social, há reviravoltas. Há rebeliões. Há movimentos insurgentes que não aceitam o que foi contado e manifestado por afetos tristes.

As narrativas do HIV e da Aids, moldados em metáforas e metonímias, não foram exaustivamente traduzidas nesse capítulo porque essa tarefa me parece impossível. As narrativas são múltiplas também. Porém, escolhi referências principais capazes de mostrar a amplitude desse panorama narrativo, além de acrescentar narrativas não tão conhecidas assim quando falamos de HIV e de Aids. As narrativas apresentadas nesse capítulo nos servem de entendimento para o movimento das contranarrativas. A partir do encontro do sujeito, individual e coletivo, com as narrativas, surge a inquietação: aceitá-las ou rejeitá-las. O processo de ressignificação, da construção das contranarrativas, surge pela rejeição dessa realidade narrativa e pela busca de uma realidade de inclusão. 


\section{Ressignificando as narrativas de uma epidemia: as contranarrativas do HIV e da Aids}

\section{1 \\ Introdução}

Apesar de todas essas narrativas, construídas por metáforas e metonímias, que fazem circular emoções e afetos, muitos deles tristes, existe um momento de pausa e de reflexão. Um momento de dizer "eu não aceito", e o anseio de contar outra narrativa, uma outra versão do HIV e da Aids, fazendo circular outras emoções e afetos. Não aceitar as narrativas do HIV e da Aids, descritas anteriormente aqui, é acolher que, dentro de si, os afetos se manifestam inquietamente sobre seu corpo. Torna-se insuportável aguentar o peso dessas construções narrativas. Busca-se por suporte, pesquisa-se em todos os lugares, procura-se uma resposta que não seja construída por essas narrativas que afastam e discriminam. Diante dessas narrativas, que aprisionam o fato de viver com HIV dentro de fronteiras excludentes, constroem-se contranarrativas que produzem afetos inquietantes e emoções imprecisas, incapazes de aceitar uma história contada exclusivamente por exclusão.

As contranarrativas, narrativas recontadas sobre o HIV e a Aids, desassemelham-se das narrativas do HIV e da Aids. Englobam um movimento narrativo de ressignificar. Partem dos sujeitos, de suas comunidades afetivas, de pesquisadores, de mim e de nós, de quem busca saber mais sobre a infecção e procura não aceitar frames depreciativos sobre o tema. As contranarrativas têm como projeto reconstruir as narrativas do HIV e da Aids a partir de um olhar sobre a pluralidade, sobre a alteridade, sobre a extinção dos estigmas das pessoas que vivem com HIV, sobre a existência de vivências plurais, sobre a importância de manter um sistema de saúde público de qualidade, sobre a persistência de democratizar o acesso universal aos antirretrovirais e a testagem em ampla escala, sobre prevenir mortalidades preveníveis, sobre expandir o conhecimento de prevenção do HIV, sobre conscientizar as práticas vulneráveis e excluir a 
construção de grupos de risco, sobre reescrever uma realidade construída pelos holofotes da exclusão.

Percebendo essa dissertação de mestrado como uma importante contribuição para as contranarrativas do HIV e da Aids, divido essa seção em duas partes. A primeira parte busca desbravar as contranarrativas e ilustrar como elas se constroem a partir do encontro com as narrativas do HIV e da Aids. Assim, elencarei a relevância de ressignificar certos termos, e produzir outros significados. A segunda seção retrata exemplos de contranarrativas a partir de outras construções. Procuro essas contranarrativas em dois arquivos específicos. O primeiro se refere ao livro desenvolvido por Artur Timerman e Naiara Magalhães sobre as "Histórias da Aids" (2015), onde muitos relatos apresentados por pessoas vivendo com HIV se apresentaram como manifestações de contranarrativas. O segundo é um documentário, "Carta para Além dos Muros" (2019), dirigido por André Canto, e roteirizado por André Canto, Gabriel Estrela, Ricardo Farias e Gustavo Mendes. Com essas duas obras, pretendo demonstrar melhor a comunicação das contranarrativas com o mundo.

Dessa forma, concluindo essas duas seções, pretendo elencar alguns pontos relevantes nesse capítulo a fim de compreender a construção das contranarrativas e o seu papel fundamental de acolher as pessoas e as comunidades excluídas pelas narrativas do HIV e da Aids. Procurarei ressaltar ainda como a circulação dos afetos e das emoções contribuem para a materialização das contranarrativas a partir do encontro com as narrativas do HIV e da Aids.

\section{2}

\section{As contranarrativas do HIV e da Aids}

"Pessoa com HIV é uma despesa para todos no Brasil", disse o presidente Bolsonaro em fevereiro de 2020. O contexto de sua fala não pode ser menosprezado. Vivíamos no Brasil em tempos nos quais a "abstinência sexual" foi “debatida" e implementada como política pública de saúde, para evitar a gravidez precoce na adolescência. A campanha ilustrava: “Adolescência primeiro, gravidez 
depois - \#TudoTemSeuTempo" ${ }^{\text {50 }}$. Em palavras contextualizadas, Bolsonaro discursa para seus apoiadores e para a imprensa ao ser questionado: "Houve uma redução no orçamento de políticas para mulheres no governo, o senhor tem a intenção de reforçar essa área para a proteção de mulheres vítimas de violência?”. As próximas falas de Bolsonaro trilham um caminho para estabelecer uma relação entre práticas sexuais e HIV. A princípio, ele retoma alguns posicionamentos da Ministra Damares sobre a defesa da abstinência sexual, evitando gravidez precoce e, em partes, evitando IST, mas com outras palavras. A ilustração da abstinência sexual na adolescência também parte de um comentário feito, certa vez, pelo jornalista Alexandre Garcia. Segundo as palavras do presidente,

O próprio Alexandre Garcia, ele fala que a esposa dele, que é obstetra, atendeu uma mulher que começou o primeiro filho com 12 anos de idade. Outro com 15, e no terceiro, que a esposa dele atendeu, ela já estava com HIV. Uma pessoa com HIV, além do problema sério para ela, é uma despesa para todos no Brasil. (EXAME, 2020) $)^{51}$

Como eu me senti com esse discurso? Péssimo. Os afetos manifestados em mim eram inquietos diante dessa fala. As falas de Bolsonaro, nesse ponto da pesquisa, já podem ser vistas como parte das narrativas sobre o HIV e sobre a Aids, principalmente se conectamos a imagem de que pessoas com HIV são párias na sociedade. Bolsonaro, como chefe de Governo e chefe de Estado, reproduziu existentes narrativas do HIV e da Aids e, como porta-voz também de toda uma Nação, desdenhou dessas pessoas e as considerou como parasitas de gastos públicos, mais conhecidos como investimentos em saúde pública. E eu, tão afetado pela força afetiva dessas narrativas, pela força que um chefe de Governo e de Estado representa para um país e para seus habitantes, senti sensações indescritíveis. Era a manifestação de afetos, ou de paixões tristes, em mim. Minhas razões para explicar a origem dessas manifestações já não cabem nesse trabalho, mas elas são reais e

\footnotetext{
${ }^{50}$ BRASIL. Ministério da Mulher, da Família e dos Direitos Humanos; Ministério da Sáude. Prevenção da Gravidez na Adolescência, 2019. Disponível em: <http://portalarquivos. saude.gov.br/campanhas/prevencaoagravidez/?fbclid=IwAR2V7hKuxKHa4F7BSqGgfZ6mpk_Mf zJtd957xozpy675q9NYQyILQGI_KfI\#/>. Acesso em: 19 maio. 2020.

${ }^{51}$ Pessoa com HIV é despesa para todos no Brasil, diz Bolsonaro. EXAME. Disponível em: <https://exame.com/brasil/pessoa-com-hiv-e-despesa-para-todos-no-brasil-diz-bolsonaro/>.

Acesso em: 19 mar. 2020. Fala confirmada com o vídeo do discurso para a imprensa e para seus apoiadores. Disponível em <https://www.youtube.com/watch?v=XkS48YU2onQ>. Acesso: 19 maio. 2020.
} 
válidas para reforçar uma decisão que me surgiu desse encontro com as narrativas do HIV e da Aids. Em uma época também turbulenta e repleta de pressões e sufocamentos acadêmicos para todos os lados, quando eu precisava delimitar um tema para meu projeto de dissertação, resolvi entender quais eram as narrativas do HIV e da Aids, para que eu também pudesse entender quais eram os efeitos da fala de Bolsonaro durante esse momento. Por isso resolvi construir uma pesquisa acadêmica para tentar explicar a manifestação das emoções e dos afetos a partir desses encontros narrativos.

Eu compartilho laços afetivos e emocionais com pessoas que vivem com HIV, mas que eu simplesmente as chamo pelos seus nomes próprios e não faço menção alguma a esse fato em nossas amizades. Assim, também influente para Inayatullah (2008), William James introduziu-me um caminho para a resposta de meus questionamentos, cujo "único caminho de apreender a espessura da realidade é experimentá-la diretamente fazendo parte da realidade do outro, ou evocando-a na imaginação com simpatia a vida interior de outra pessoa"52 (JAMES, 1909 apud INAYATULLAH, 1998). As narrativas do HIV e da Aids são direcionadas a certos grupos sociais, como visto anteriormente, assim, qualquer pessoa que não esteja incluída nesses grupos vulneráveis pode compreender que se encontra livre de qualquer possibilidade de infecção com o HIV. Esse fato reforça o descompromisso com a verdade sobre o HIV e a Aids, no que se refere à saúde pública, no discurso de Bolsonaro, porque, por mais implícito esteja, ele mobiliza outros elementos das narrativas do HIV e da Aids. Sua fala manifesta afetos e emoções nesses grupos e em pessoas ligadas a eles, seja por laços próximos, seja por simples alteridade. Desse momento inquieto para mim, e com a decisão de construir uma dissertação de mestrado relacionada às narrativas do HIV e da Aids, percebi que eu fazia um movimento oposto às próprias narrativas. Eu não as reproduzia aleatoriamente, como desconhecedor de seus efeitos, mas as ressignificava. Nesse processo de ressignificação, descobri que muitas pessoas já o faziam e o fazem a fim de reverter a deterioração e a corrosão causada por aquelas narrativas. Agora, as contranarrativas apareciam e despertavam em mim um desejo político e social de

\footnotetext{
${ }^{52}$ Tradução livre. No original: "The only way in which to apprehend reality's thickness is either to experience it directly by being a part of reality one's self, or to evoke it in imagination by sympathetically divining some one else's inner life".
} 
me integrá-las. Essa dissertação, despretensiosa em toda a sua origem e de qualquer grande reconhecimento futuro, insere-se como uma pequena contribuição no vasto universo das contranarrativas do HIV e da Aids. A fala corrosiva do presidente Bolsonaro me incentivou a construir ciência. É sobre ecoar as vozes dos outros em nós mesmos (SPIVAK, 2010).

Assumo-me como um pesquisador que tece as narrativas nas Relações Internacionais. Assim, reforço que: Tecer (vtd), de acordo com dicionário Aurélio, significa: "1. Entrelaçar regularmente os fios de. 2. Fazer (teia ou tecido) com fios. 3. Engendrar, armar. 4. Compor, entrelaçando. 5. Fig. Compor (obra que exige trabalho e cuidado). int. 6. Exercer o ofício de tecelão. Enredar-se" (FERREIRA, $2010)^{53}$. Mas, ao invés de trabalhar com fios, eu trabalho com narrativas. Minha intenção é entrelaçar as narrativas sobre o HIV e a Aids de pessoas vivendo com HIV para construir esse trabalho. As narrativas, dessa forma, ilustram a relação sujeito-mundo para o pesquisador, sem que ele faça parte desse processo diretamente, tornando-o um tecelão das narrativas contatadas, permitindo-o enxergar, ao menos, o que os sujeitos das narrativas viram com seus olhos (INAYTULLAH, 1998).

Parte desse processo sobre tecer narrativas advém da apreensão de diversas leituras que elucidam esse processo contranarrativo nos documentos escolhidos (NASCIMENTO, 1998; CARVALHO, 2015; DOURADO, 2015; TIMERMAN et al, 2015; INÁCIO, 2016; BRAGANÇA et al, 2017; DUARTE et al, 2017; KIND et al, 2017; DAMASCENO et al, 2019). As contranarrativas surgem como respostas às narrativas do HIV e da Aids. Na vida de uma pessoa que vive com HIV, elas podem aparecer, senão anteriormente em sua vida por processos de vivência ou de aquiescência dessas expressões em sua comunidade afetiva, nos momentos seguintes ao conhecimento do status sorológico. Uma das buscas pelas contranarrativas advém da troca de experiência com outras pessoas que vivem com HIV. As contranarrativas surgem desse movimento de afetar e de ser afetado. Elas emergem, e a manifestação de afetação dos acontecimentos surge como um "motor para as próprias transformações físicas e psicossociais que experimentamos em nossas trajetórias individuais e sociais (...). Assim, nossos corpos, em sua inevitável

\footnotetext{
${ }^{53}$ FERREIRA, Aurélio Buarque de Holanda. Mini Aurélio: o dicionário de língua portuguesa. Coordenação de edição Marina Baird Ferreira, 8. Ed. Curitiba: Positivo, 2010.
} 
transformação ao longo dos anos, constituem uma importante narrativa sobre nossas experiências" (CARVALHO, 2015, p. 257).

As comunidades online, seja através de grupos de Facebook (DUARTE et al, 2017), Twitter (BRAGANÇA e GOVEIA, 2017) ou Blogs (TIMERMAN e MAGALHÃES, 2015) representam a inserção dessas pessoas - com pouco conhecimento sobre as contranarrativas do HIV e da Aids - nessas comunidades sobretudo para buscarem informações capazes de aquietar a manifestação afetiva em seu corpo. E elas encontram nessas plataformas, já circulantes em seus membros, um processo narrativo de desmistificação e de encorajamento sobre a realidade de viver com HIV, embora existam, de forma minoritária, pessoas que ainda reproduzam as narrativas do HIV e da Aids mesmo em grupos prevalentes com contranarrativas.

Ainda, destaca-se que pesquisas como as descritas aqui, que desvendam e transcrevem as relações em redes sociais, são relevantes para apontar o papel dessas redes nas experiências das pessoas que vivem com HIV, um vírus o qual ainda não é totalmente erradicado do corpo. Além disso,

\begin{abstract}
a condição de viver com o HIV/Aids é tomada como um tipo de adoecimento e sofrimento de longa duração ou doença comprida, na perspectiva antropológica. Essas nomenclaturas, suscitadas em contextos etnográficos, buscam provocar o caráter hegemônico do termo 'doença crônica', cunhado pela medicina moderna, na medida em que tentam registrar e nomear 'aquilo que veio para ficar'. (DAMASCENO, et al 2019, p. 2).
\end{abstract}

É essa relação, de viver com HIV e acreditar em um primeiro momento que se trata de uma infecção repleta de sofrimentos, que impulsiona também a busca por grupos sociais em redes digitais. Se o HIV e a Aids não tivessem persistido narrativamente como sofrimento certeiro em uma época com antirretrovirais, e até o desenvolvimento efetivo de vacinas contra o vírus, talvez a história do HIV e da Aids tivesse sido diferente. Mas essa dissertação não é sobre análise de conjuntura de cenários imagéticos. Aqui, busco compreender fontes e manifestações reais de apoio comunitário e de construção de contranarrativas que buscam ressignificar aquilo que não foi: uma infecção crônica sem estigmatização e exclusão.

Duarte et al (2017) e Damasceno et al (2019) fizeram um estudo tentando compreender como a sociabilidade entre pessoas que vivem com HIV se desenvolve em grupos fechados do Facebook. O objetivo é compreender as narrativas de jovens 
em torno do HIV e da Aids, adentrando-se em suas tensões quotidianas. Entretanto, eu observo que esse estudo permite a compreensão das manifestações de contranarrativas em comunidades online, nesse caso, no Facebook. As “sociabilidades positivas" descritas pelos autores são exemplos dos desdobramentos das contranarrativas: construir comunidades com narrativas outras. Ao conectar-se com o outro, a partir de inquietações próprias, descobre-se uma realidade outra, bem diferente das primeiras impressões construídas pelas próprias narrativas do HIV e da Aids. Pertencer a uma comunidade online é procurar fontes de lugares que produzem e reproduzem contranarrativas, representadas por narrativas de suporte, de apoio, de direcionamento em momentos turbulentos, de inclusão de pessoas que são marginalizadas pelas narrativas do HIV e da Aids (DUARTE et al, 2017). Nesse momento de contato com o outro, as contranarrativas são produzidas e produzem sentidos outros.

Foi observado que dentro de grupos online, principalmente aqueles intencionados a ressignificar as narrativas do HIV e da Aids, há o suporte, o apoio e o desejo de pessoas que vivem com HIV de buscar informações que dialoguem com seus afetos e emoções ao mesmo tempo que existe, por meio dos outros participantes, um sentimento manifestado de acolhimento (DUARTE et al, 2017). Ao buscar um grupo de Facebook, nessas características descritas até aqui, percebese que existe uma manifestação afetiva e emotiva nessas pessoas a não aceitarem as narrativas do HIV e da Aids que lhe foram postas antes da descoberta da sorologia, e esses afetos as impulsionam a não aceitar essas descrições metaforizadas e metonímicas da infecção. Quem se descobre vivendo com HIV busca se informar cada vez mais sobre os passos da infecção, e a busca por comunidades é uma tentativa de fugir das reações de distanciamento provocadas sobre os corpos e uma tentativa de aproximar-se de outras histórias, muitas vezes semelhantes à sua própria. Esses grupos de Facebook, ou conexões geradas pelo Twitter, Instagram e Blogs, tornam-se fontes descentralizadas de contranarrativas. No exemplo do Facebook (DUARTE et al, 2017), a comunidade tornou-se um lugar de construir a aceitação sorológica, ou seja, de ressignificar as narrativas do HIV e da Aids, mostrando às pessoas recém-chegadas representações diferentes às já existentes, narrando que HIV não é Aids e, principalmente, que Aids não é mais morte. Além dessas ressignificações, ocorre ainda a troca de conhecimento e de experiência sobre as formas de tratamentos e de prevenção também, principalmente 
discussões acerca da medicação e de medicações profiláticas (DUARTE et al, 2017).

Os autores ainda ressaltam duas características relevantes nesse desenvolvimento da pesquisa, e com diversas outras pesquisas intencionadas a trazer a Internet para a discussão, o debate entre o mundo online e offline. Pois, antes de tudo, é imprescindível "reconhecer a interação complexa e imbricada entre os mundos online e offline e, nessa direção, focalizar as transformações mútuas e múltiplas: da tecnologia, dos próprios usuários e de suas culturas" (DUARTE et al, 2017). Assim, utiliza-se de fontes online para a ressignificação da vida offline, embora a vida online e offline estejam totalmente conectadas em uma era digital. As identidades e a própria construção e reprodução das contranarrativas são, nesse caso, construídas inteiramente online e servem de suporte para a vida que ocorre offline, embora, em alguns casos, a vida online possa transbordar a vida offline a partir de relacionamentos entre os membros dessas comunidades que morem próximos ou que estejam dispostos a se deslocarem para se reunirem com outros membros (DUARTE et al, 2017).

No grupo secreto do Facebook, Damasceno et al (2019) observaram

\begin{abstract}
inúmeras iniciativas de organização de encontros offline entre membros do grupo que moravam na mesma cidade ou região, principalmente em finais de semana e feriados. Esses encontros ocorriam em parques públicos, bares, casas ou apartamentos. No fim dos encontros offline, essas pessoas costumavam postar fotos no grupo, nas quais apareciam sorridentes e felizes por poderem se socializar sem a necessidade de esconder sua sorologia. Em abril de 2017, por exemplo, foram postadas fotos de um encontro em São Paulo entre dez rapazes, todos membros do grupo. Os comentários da postagem ressaltavam a importância desses encontros: 'semana que vem podia rolar em Brasília' (João, 23 abr. 17); e 'MASSA!!! Nunca deixem de se apoiar, fortalecer e seguir adiante na luta por QUALIDADE de vida!!' (Júnior, 23 abr. 17). (DAMASCENO et al, 2019, p. 10)
\end{abstract}

Essa complementação entre online e offline construída nesses espaços virtuais "necessitam ser compreendidas como um continuum online e offline, e não como duas realidades que se excluem mutuamente (real versus virtual), de maneira que precisamos evitar reificar esses espaços e as relações que neles se desenvolvem" (DAMASCENO et al, 2019, p. 15-16). O que se mostra desafiador para os pesquisadores interessados em compreender essa dupla e singular realidade 
é "analisar os fluxos interacionais que, mesmo acontecendo online, estão diretamente imbricados com a realidade objetiva desses sujeitos e com seus pertencimentos sociais de gênero, classe social, raça, sexualidade, geração" (DAMASCENO et al, 2019, p. 16).

A rotina do grupo no Facebook foi descrita por Duarte et al (2017) por girar "em torno do acolhimento de novos membros e do compartilhamento de experiências pessoais, dúvidas sobre o tratamento antirretroviral acerca do HIV e da Aids" (DUARTE et al, 2017). Além disso,

seus usuários podem, portanto, conversar sobre suas vidas cotidianas e, também, sobre suas rotinas de uso de terapia antirretroviral, utilizando-se de nomenclaturas e termos biomédicos e farmacológicos para definirem o que estão sentindo ou como procedem na administração de suas rotinas atravessas pelo HIV. (DUARTE, et al, 2017, p. 342)

É de práxis que os novos integrantes desse grupo do Facebook se apresentem quando sua entrada for aprovada pela moderação (DUARTE et al, 2017). Esse processo de apresentação, um post introdutório à comunidade ou um extenso comentário incluindo informações relevantes em destaque sobre o motivo de estar ali pode ser visto como um momento autobiográfico do sujeito? Essa é uma questão a ser discutida. Em uma época de tempo escasso e de sintetizar informações para economizar esse mesmo tempo escasso, o comentário ou o post de apresentação não pode estender-se por muitos caracteres. É essa a dinâmica das redes sociais. Porém, por mais sintetizadas que essas apresentações possam ser, essa expressão perpetua o sujeito narrador ocupando a cena, juntamente com outros sujeitos narradores, levando em consideração “fatos e personagens do passado [que] ganham sentido na medida em que se apresentem como elementos relevantes na reconstrução da vida do sujeito" (NASCIMENTO, 1998, p. 159). Os fatos de uma apresentação envolvem elementos circundantes à vida da pessoa que vive com HIV: o passado, considerado como a vida antes da descoberta do status sorológico; a dinâmica da vida pessoal, convivências múltiplas com a família, amigos, conhecidos, colegas de diversas formas; o momento da descoberta do HIV; os momentos de encontro com as narrativas do HIV e da Aids; a manifestação em seu circuito de afetos e a decisão de buscar realidades parecidas; o encontro de grupos de apoio e de suporte para enfrentar os afetos da descoberta; o encontro com as 
contranarrativas e o seu processo de ressignificação. Diversos encontros e sujeitos envolvidos nesse processo podem compor um comentário ou um post de apresentação, levando a acreditar que a autobiografia se constrói nas redes sociais e são fundamentais para a edificação das contranarrativas. Principalmente porque esse momento de apresentação - de expressão autobiográfica dos sujeitos representam também um processo de compreensão de seus afetos e de suas emoções. É porque o outro está aberto à troca de experiência e está aberto ao apoio que percebemos a importância de criar conexão humana em redes digitais.

Essa sociabilidade descrita por Duarte et al (2017) apresenta uma característica fundamental das contranarrativas: elas surgem, antes de tudo, para ressignificar narrativas para si próprio. As contranarrativas não precisam, em um primeiro momento, falar à toda sociedade. Primeiramente, elas se situam entre as pessoas que vivem com HIV e em seus circuitos afetivos mais limitado, e a partir desse entendimento e dessa compreensão interna, as contranarrativas tornam-se instrumentos de mudança. Gera-se uma contranarrativa no debate, quando duas pessoas compartilham experiências e debatem sobre suas próprias realidades circundantes e, fundamentalmente, quando não se entregam ao abismo das narrativas do HIV e da Aids. As "sociabilidades positivas" demonstram como

\begin{abstract}
no caso específico da Aids, pode-se dizer que indivíduos que antes do diagnóstico nada tinham em comum agora encontram no próprio corpo um 'marcador' que os agrega, que os mobiliza para a formação de uma coletividade. O sentimento de pertencimento a esse grupo (de pessoas vivendo com HIV/Aids), ainda que não seja unidirecional, na medida em que existem trajetórias de vida (e infecção) diferentes para cada sujeito, emerge a partir do diagnóstico de sorologia positiva para HIV e é vivenciado, dentre outros aspectos, no cotidiano de idas ao ambulatório médico, no aprendizado e compartilhamento de termos médicos que instrumentalizam a leitura sobre a própria condição sorológica (CD4, carga viral, sistema imunológico, adesão ao tratamento, profilaxia pré e pós-exposição, etc.) e na construção e apropriação da categoria 'pessoa vivendo' e 'jovem vivendo' como expressões de suas identidades. (DUARTE et al, 2017, p. 346)
\end{abstract}

Embora eu esteja em desacordo com a insinuação de que pessoas vivendo com HIV tenham seus corpos "marcados", como sinalizaram e destacaram os autores, acredito que essa reflexão em torno do pertencimento ao grupo destacado resume parte dos efeitos das contranarrativas: a produção de novas narrativas de si 
a partir do contato com o outro e com as contranarrativas construídas a partir desse encontro. Não devemos sinalizar, muito menos distinguir os corpos, as pessoas que vivem com HIV como pessoas marcadas, como apresentou o trecho acima, pois esse fato retoma a dualidade de exclusão e inclusão dessas pessoas na sociedade e ressaltam alguns dos elementos das narrativas do HIV e da Aids que buscamos ressignificar a partir de nossas pesquisas e de nossas ações no mundo. As narrativas do HIV e da Aids são especialistas em segregar pessoas que vivem com HIV, as contranarrativas surgem para agrupar novamente uma sociedade corrompida pelo estigma da existência do outro. E quando eu escrevo ou me refiro ao "outro", não busco distanciá-lo de mim, pois eu os conheço e a eles construo essa contranarrativa em forma de dissertação. Porém, cabe assinalar, antes de tudo, que as identidades se modificam a partir do encontro com a infecção e, novamente, modificam-se a partir do encontro com as contranarrativas. Existem outros meios pelos quais os afetos das contranarrativas podem ser mobilizados, como na vinculação em formas de mobilização social, podendo ser redes políticas e de apoio, ONGs, redes sociais de relacionamento na internet, e que, por sua vez, coloca

\footnotetext{
em evidência $\mathrm{o}$ aspecto político das identidades, já que categorias são usadas e propagadas a fim de que indivíduos identifiquem a si mesmos como pertencentes a determinados grupos e, assim, seja possível o investimento em ações protagonizadas por eles mesmos (reivindicações por políticas públicas, por exemplo). (DUARTE et al, 2017, p. 350)
}

Por mais que Duarte et al (2017) tenha apresentado como algumas contranarrativas se produzem em grupos de Facebook, existem integrantes dos grupos que continuam a reproduzir as narrativas do HIV e da Aids, expondo ainda estigmas e desinformação para os novos integrantes do grupo. As relações de estigma, preconceito, marginalização e depreciação continuam a ocorrer, mesmo em ambientes repletos de contranarrativas. Explica-se, assim, que nem todas as comunidades de contranarrativas expressam em sua integralidade argumentos ressignificados sobre a infecção, pois pode acontecer que o mesmo grupo que acolhe reproduza "conflitos morais, ou mesmo que, nesses grupos, como sinaliza Goffman (2015, p. 47), ao falar sobre a 'ambivalência de vinculação do indivíduo com a sua categoria estigmatizada', não possam ocorrer 'oscilações no apoio, identificação e participação que tem entre seus pares"” (DUARTE, 2017, p. 347). 
Os integrantes dessa comunidade, por compreenderem grande parte das contranarrativas do HIV e da Aids, ainda estão sujeitos a reproduzir de distintas formas reações de distanciamento entre os corpos, delimitando novamente a fronteira com o outro (AHMED, 2014).

Bragança e Goveia (2017) também se depararam com a manifestação de estigmas e preconceitos mascarados de "brincadeira" em postagens no Twitter. Eles discorrem que

tais postagens, tanto quanto as pejorativas, vão na contramão da luta pela saída simbólica de soropositivos da marginalidade, bem como para a propagação de informações precisas acerca do tema. [...] os discursos eram, muitas vezes, tão cruéis e despreocupados com a realidade social que as linhas entre 'piada' e discurso de ódio eram extremamente tênues. (BRAGANÇA e GOVEIA, 2017, p. 9)

Levamos a acreditar na existência também de estigmas e preconceitos em redes sociais, dividindo espaço, um pequeno espaço, nas plataformas onde também são produzidas e compartilhadas as contranarrativas do HIV e da Aids. Assim como foi observado nos grupos do Facebook, o Twitter também não está livre dessas narrativas marginalizantes da infecção, reforçando a barreira de exclusão das pessoas que vivem com HIV também nessas redes digitais. Mas não se pode negar que o Twitter também se apresente como uma rede social que incentiva o diálogo direto com esse público mais jovem, "se diferenciando das inserções pontuais existentes nas lógicas publicitárias, além de fornecer um canal de comunicação contínuo em que usuários podem não só propagar informações através do compartilhamento, mas criar suas próprias narrativas (BRAGANÇA e GOVEIA, 2017, p. 13).

São nessas redes sociais e digitais que a expressão também autobiográfica de cada pessoa se torna viável para o compartilhamento de contranarrativas individuais, de olhares singulares e únicos sobre suas experiências ao longo da descoberta do HIV e do encontro com identidades resilientes às narrativas do HIV e da Aids. A fragmentação da autobiografia nas redes sociais, visto que nem sempre há espaço e tempo para uma aprofundada e detalhada autobiografia compartilhada entre outras autobiografias em forma de comentário ou de post, desenha o autornarrador que, 
ao contrário dos profissionais da saúde, dos pesquisadores, constrói para si uma imagem da doença a partir da experiência da própria condição de doente. Esta condição, bem entendido, implica em sentir medo, em sofrer, em ser tomado por um 'sentimento de urgência', de resto inteiramente desconhecido pelos outros. O doente é aquele que vivencia a inexorabilidade de seu mal, mais do que isso, no casso do aidético, é aquele que experimenta a sensação de assumir pouco a pouco a imagem da doença. (NASCIMENTO, 1998, p. 163)

Essa manifestação afetiva e emotiva que foi traduzida como um sentimento de urgência, implicando a expressão da autobiografia, conecta-se totalmente com o anseio da produção de contranarrativas. Não se deve descartar que essas são geradas a partir do efeito afetivo e emocional que as narrativas do HIV e da Aids provocaram dentro de si. É uma busca pela não aceitação que exista um fim tal como essas narrativas pregam ou que o sofrimento pela Aids ainda possa acontecer apenas pela descoberta do HIV. São afetos e emoções escritas em fragmentos de autobiografia nas redes socias (BRAGANÇA e GOVEIA, 2017; DUARTE et al, 2017; DAMASCENO et al, 2019). Porém, é preciso destacar alguns pontos sobre a citação acima, principalmente a consideração de que quem tem Aids é considerado "aidético", pois esse termo ainda pertence às narrativas do HIV e da Aids e é estigmatizador. Além disso, a consideração de que quem tem HIV ou Aids é considerado "doente" ou observar ainda que a Aids é uma "doença". Como ressalta Sontag (1989), a Aids é um estado clínico e não uma doença, e tal estado permite a manifestação de infecções oportunistas.

Nessas redes sociais, as autobiografias são compartilhadas e, juntas, agregam força às contranarrativas do HIV e da Aids. Destaca-se, ainda, que a autobiografia é uma construção individual e representa uma construção singular de uma experiência. Nessa troca de histórias, as experiências individuais não deveriam ser tomadas como universais, mas isso não significa dizer que elas não possam compor e agregar elementos comuns a contranarrativas maiores. Nesses espaços, assim, “a narrativa autobiográfica busca reconstituir uma experiência de vida, ou pelo menos, aquela parte da experiência do próprio autor que lhe faça sentido" (NASCIMENTO, 1998, p. 164). Torna-se uma reconstrução de experiência de vida. Nos comentários e nos posts de apresentação, percebe-se ainda relação importante da construção autobiográfica: o ponto de encontro em expressar a manifestação afetiva e sentimental produzidas pelas narrativas do HIV e da Aids e a não aceitação dessas 
narrativas (NASCIMENTO, 1998; DUARTE et al, 2017). Desse momento, a escolha de rejeitar elementos importantes das narrativas também se expressa na decisão de procurar grupos de apoio e suporte online capazes de aquietar parte de seus afetos e produzir afetos outros

Esses espaços delimitados por expressões humanas contribuem juntos para impedir a "morte dos afetos":

visto que não mais se morre por HIV, continua-se ainda a morrer no silêncio da impossibilidade de revelação da situação sorológica das pessoas; na rejeição advinda de uma exposição pública, o que envolveria a morte dos afetos e mesmo, ainda aspectos como vergonha, silenciamento, abandono, mesmo em se tratando de tratamentos eficazes como os que há hoje. (DAMASCENO et al, 2019, p. 16)

Convém assinalar que a expressão utilizada "morte dos afetos" se diferencia da proposta de Safatle (2015) sobre os circuitos de afetos. Porém, o que importa salientar é que as narrativas do HIV e da Aids contribuíram para a exclusão de pessoas vivendo com HIV da sociedade, lançando-lhes, além de estigmas, fardos que não lhe pertenciam para carregar. A morte dos afetos expressa por Damasceno et al (2019) é o efeito afetivo das narrativas sobre as vivências individuais, motivando-as a compreender uma vivência coletiva, uma verdadeira vivência com HIV e atingir finalmente um momento em que se descobre que não se tratava da morte dos afetos, apenas uma manifestação de paixões tristes em um período de tempo (NASCIMENTO, 1998; DUARTE et al, 2017; SAFATLE, 2015).

No Twitter, Bragança e Goveia (2017) intencionaram-se na descoberta de como essa rede de sociabilidade poderia "fornecer indício para compreender como é feita a comunicação dessa temática para a população, em especial, jovem" (BRAGANÇA e GOVEIA, 2017, p. 1). Além de uma rede social de expressão e de peso, que levanta a todo momento hashtags com os eventos mais debatidos no dia, o Twitter se tornou uma rede social influente na divulgação de campanhas preventivas ao HIV, visto que "essas campanhas também se concentram em dialogar com a população acerca da prevenção (geralmente campanhas de conscientização do uso da camisinha" (BRAGANÇA e GOVEIA, 2017, p. 4). Mas que, por outro lado, essas campanhas por parte do Governo, por exemplo, esquecem-se "de abordar outras temáticas extremamente importantes, como a discriminação com as populações soropositivas e o convívio com a doença pelos 
infectados" (BRAGANÇA e GOVEIA, 2017, p. 4). Embora eu não esteja de acordo com os termos utilizados pelos autores, a exemplo de "infectados" e "doença", não se pode desprezar parte de sua argumentação sobre companhas de conscientização e prevenção do HIV. Essas abordagens muitas vezes reforçam laços extensivistas da atuação do Estado em saúde pública (PASSOS e BARROS, 2009), ou seja, restringem a infecção a um grupo específico, "ao qual até bem pouco tempo o discurso médico-político-científico referiu-se como 'grupo de risco', metodologia ainda hoje, se não adotada, assumida por muitos como norma e orientação para a construção de políticas públicas" (INÁCIO, 2016, p. 487).

É fundamental destacar que, após o discurso de Bolsonaro, no qual ele atribui à pessoa vivendo com HIV despesas para todos no Brasil, o Twitter se mobilizou os usuários do Twitter, no caso - para levantar uma campanha a partir de hashtag e produzir, instantaneamente, um destaque contranarrativo ao presidente: surgia a expressão \#EuNãoSouDespesa. Além do Twitter, Facebook e Instagram, por exemplo, também tiveram a manifestação de seus usuários. Essa campanha também teve apoio do Conselho Nacional de Saúde, vinculado ao Ministério da Saúde, intencionando-se em levantar depoimentos contra a discriminação de pessoas que vivem com HIV. Usufruindo dessas plataformas midiáticas, diversos relatos contra o discurso de Bolsonaro foram feitos, tendo como um dos focos principais a defesa e a luta pelo Sistema Único de Saúde, sempre ameaçado por discursos de privatização e de cortes orçamentários.

A campanha no Twitter também teve um componente visual. Não se tratava apenas de comentários contrários a Bolsonaro, e de relatos de vivência e de experiência individual. Construíram-se também contranarrativas visuais: viam-se os rostos, os nomes, os sobrenomes, as idades, as expressões faciais, as características singulares a partir de fotos das pessoas que lutavam por ressignificar as narrativas do HIV e da Aids. O discurso de Bolsonaro ascendeu emoções e lutas constantes para a ressignificação das narrativas.

Sem a constituição dessas comunidades virtuais, as contranarrativas do HIV e da Aids não surtiriam tanto efeito na vida das pessoas que vivem com HIV, visto que as grandes mídias se tornaram difusoras das narrativas do HIV e da Aids e pouco têm mostrado interesse na ressignificação desse passado. Embora elas pareçam dispostas a pregar pelo respeito e se apresentem como contrárias a todas as formas de estigmatização e preconceito, as notícias sobre o HIV e sobre a Aids 
pouco aparecem nos noticiários. Mas é no espaço digital, fora da área de cobertura dessas grandes mídias, que se impulsiona a coletividade e desmistifica-se a separação de mundos online e offline. Construir investigações assim apresentam ainda muitos desafios, como coloca os autores, visto que

por fim, políticas, ao trazer à tona pessoas, socialidades, ações, lugares e moralidades do mundo online e offline que, por se localizarem às margens da política e das práticas sanitárias oficiais, modela a experiência com 'algo tão simples de viver e controlar, mas difícil de compartilhar e defender', como escreveu um de nossos interlocutores. (DAMASCENO et al, 2019, p. 3)

A construção coletiva de contranarrativas do HIV e da Aids inclui ainda a desconstrução online de alguns dos segredos mantidos pelas pessoas vivendo com HIV que, na hora da apresentação aos grupos, revelam o que no mundo offline dificilmente revelariam. O segredo e o silêncio por trás do viver com HIV é ainda uma escolha individual e não deve ser outorgada a ninguém mais. Damasceno et al (2019) analisam

\begin{abstract}
que o segredo/silêncio instaura uma contradição no viver com o HIV/Aids como uma condição de longa duração, na medida em que a restrição contemporânea dos discursos sobre a doença traz à luz dimensões simbólicas antes narradas como 'morte civil' por ativistas vinculados ao movimento social em HIV/Aids nos anos 1980. No contexto atual, essa 'morte civil' tem se atualizado como uma 'doença-segredo', implicando uma nova forma de morte simbólica. (DAMASCENO et al, 2019, p. 15)
\end{abstract}

Escrever sobre o silêncio e segredo é ainda possível quando se escolhem nomes ficcionais, mas com relatos verdadeiros, na construção de blogs também (TIMERMAN e MAGALHÃES, 2015). Aqui, a autobiografia fragmentada pelos espaços e pelo tempo dessas pessoas não necessariamente enfrenta o silêncio ou segredo, a não ser das pessoas integrantes ao grupo que não querem interagir por razões a parte, porque é na intenção de abrir um pouco de si que o acolhimento ganha forma pelas interações. Saliento ainda que o fato de se integrar a essas comunidades virtuais repleta de desconhecidos facilita a expressão autobiográfica e o compartilhamento dos segredos construídos em torno do HIV no mundo offline. Quando se está em família, ou até mesmo com amigos próximos, o medo de quebrar esses laços afetivos e emocionais com essas pessoas por dizer que se vive com HIV reforça a ideia de segredo e força ao silêncio (FRISSO, 2021). 
Um dos elementos destacados por Duarte et al (2017) sobre algumas das perguntas debatidas entre os membros do grupo do Facebook é a constante vigilância sobre o uso dos antirretrovirais, principalmente no que lhes concerne a regularidade das doses. Pois, "a oferta ou disponibilidade de serviços não significa, necessariamente, uso efetivo dos mesmos" (DOURADO et al, 2015). Existem vários obstáculos, desafios ou barreiras "ao acesso e cuidados em saúde pelos quais passam as pessoas vivendo com HIV/Aids, como por exemplo, desigualdades socioeconômicas, dificuldades financeiras e de recursos sociais, barreiras geográficas e culturais, diferenças de gênero e o próprio estigma em relação ao HIV/Aids" (OLIVEIRA, 2009 apud DOURADO et al, 2015, p. 952-953). Os autores ainda elencam algumas das estratégias usadas para não revelar que se vive com HIV por parte das pessoas entrevistadas na Bahia, em um estudo que não se conecta com as redes sociais, mas implica as narrativas de idas e vindas ao serviço de saúde para diagnóstico e tratamento do HIV e da Aids. Umas dessas estratégias para esconder ou não revelar o motivo do uso dos medicamentos "é fazer referência à 'vitamina', dizer que é 'diabético', que tem 'problema de açúcar no sangue', entre outras justificativas, mostram também a dificuldade em revelar a soropositividade" (DOURADO et al, 2015, p. 968). Um marco importante para o tratamento do HIV e da Aids, principalmente para a desconstrução de metonímias que conectavam a Aids à morte, foi a disponibilização em 1996 da terapia antirretroviral (TARV) conhecida como "coquetel" no Brasil (KIND, 2017). O uso contínuo dos antirretrovirais e o controle da ciência sobre o HIV constituiu também outra narrativa às pessoas que vivem com HIV. Se no começo da epidemia, os corpos eram denunciados pelo estado clínico da Aids e eram visivelmente enxergados como corpos doentes (TIMERMAN e MAGALHÃES, 2015), agora a narrativa se modifica a partir do uso contínuo da medicação. Assim

os corpos, após o sucesso da medicação com o coquetel que inibe a replicação do HIV, mantendo os usuários, quando não sofrem rejeição aos componentes dos medicamentos, em condições de saúde idênticas às de qualquer pessoa com doença crônica, já não mais 'denunciam' a Aids como nos primeiros anos de difusão da epidemia. Novas narrativas corporais são assim tecidas, (...) mantendo-se as especificidades de cada história de vida. (CARVALHO, 2015, p. 268) 
Há de se considerar que a descrição dos medicamentos antirretrovirais também se insere no processo contranarrativo, principalmente ao notar que a realidade do tratamento da infecção modificou-se significativamente ao longo dos anos. Assim como alguns autores mencionaram o uso de "coquetel" ao tratamento antirretroviral (BARATA, 2006; CARVALHO, 2015; TIMERMAN e MAGALHÃES, 2015), reformula-se a compreensão e a própria narrativa de tratamento do HIV ao ressignificar o uso da palavra "coquetel". A origem do nome sugeria a relação de inúmeras composições medicamentosas, com inúmeros comprimidos a serem ingeridos por dia. Porém, “o uso do termo coquetel também não é mais frequente, pois o tratamento antirretroviral tem sido simplificado. Atualmente, há muitas pessoas que tomam apenas 1 ou 2 comprimidos com medicamentos combinados por dia" (UNAIDS, 2017, p. 10).

A ressignificação de termos é fundamental para a ressignificação das narrativas do HIV e da Aids e da construção efetiva e sólida de suas contranarrativas. Não é para menos que "a linguagem molda o pensamento e pode influenciar comportamentos" (UNAIDS, 2017, p. 7). A ideia de que a linguagem molda o pensamento e influencia comportamentos tem, como exemplo, as narrativas do HIV e da Aids como movimentos de exclusão das pessoas que vivem com HIV ou de pessoas que viviam com Aids nos anos mais difíceis da epidemia. O surgimento das metáforas e das metonímias da exclusão e o fortalecimento dos estigmas a determinados grupos sociais se insere nessa influência comportamental e da modulação do pensamento. Esse pensamento influenciou a construção das fronteiras entre o eu e o outro (AHMED, 2014).

No mesmo movimento de construir contranarrativas do HIV e da Aids, a UNAIDS lançou em 2017 um Guia de Terminologias, intencionando-se, principalmente, na ressignificação dos termos apropriados quando formos nos referir à realidade circundante do HIV e da Aids. Assinala-se também que "a utilização de linguagem apropriada tem o poder de fortalecer a resposta global à epidemia de Aids" (UNAIDS, 2017, p. 7). Mas, eu percebo que, para além do caráter global do combate à epidemia, o Guia de Terminologias serve à sociedade e aos pesquisadores como uma rica fonte de produção de contranarrativa. Tornouse um dicionário comparativo de termos que eram utilizados, ou já foram utilizados, para se referir à epidemia do HIV e às pessoas que vivem com HIV juntamente com termos substituídos, de certa maneira, visando uma Abordagem Baseada em 
Direitos Humanos (UNAIDS, 2017, p. 9). Em uma tentativa de dialogar com o Guia de Terminologias do UNAIDS e com a abordagem utilizada nesse trabalho, separei alguns vocabulários ressignificados que edificam as contranarrativas e sistematizei na seguinte tabela:

\section{Tabela II: Termos que edificam as Contranarrativas}

\begin{tabular}{|c|c|c|}
\hline Não Utilizar & Contextualização & Termo Recomendado \\
\hline $\begin{array}{l}\text { Contaminado(a)/pessoa } \\
\text { contaminada com HIV }\end{array}$ & $\begin{array}{l}\text { Contaminação e infecção possuem } \\
\text { diferentes significados. Contaminação se } \\
\text { refere à transmissão de impurezas e } \\
\text { infecção se refere à invasão de tecidos } \\
\text { corporais de um organismo hospedeiro } \\
\text { por parte de organismos capazes de } \\
\text { provocar doenças. Assim, devemos dizer } \\
\text { que uma pessoa foi "infectada" com HIV } \\
\text { e não "contaminada" }\end{array}$ & $\begin{array}{l}\text { Pessoa vivendo com HIV } \\
\text { Além disso, não se deve } \\
\text { referir às pessoas como } \\
\text { uma abreviação, como } \\
\text { PVHA (Pessoas Vivendo } \\
\text { com HIV e AIDS), porque } \\
\text { desumaniza o indivíduo }\end{array}$ \\
\hline $\begin{array}{l}\text { Doença mortal, incurável; } \\
\text { doença crônica } \\
\text { deficiência imunológica }\end{array}$ & $\begin{array}{l}\text { Rotular a Aids como mortal ou incurável } \\
\text { gera medo, além de aumentar o estigma e } \\
\text { a discriminação. Dizer que se trata de uma } \\
\text { doença crônica tratável pode influenciar a } \\
\text { sociedade a acreditar que a doença não é } \\
\text { tão grave }\end{array}$ & $\begin{array}{ll}\text { Síndrome } & \text { da } \\
\text { Imunodeficiência } & \\
\text { Adquirida (AIDS) } & \end{array}$ \\
\hline $\begin{array}{l}\text { Doença venérea; doença } \\
\text { sexualmente } \\
\text { (DST) }\end{array}$ & $\begin{array}{lrr}\text { Muitas infecções } & \text { sexualmente } \\
\text { transmissíveis (IST) não causam sintomas }\end{array}$ & $\begin{array}{ll}\text { Infecção } & \text { Sexualmente } \\
\text { Transmissível (IST) }\end{array}$ \\
\hline $\begin{array}{l}\text { Grupos de risco; grupos de maior } \\
\text { risco; grupo de alto risco }\end{array}$ & $\begin{array}{l}\text { O fato de pertencer a grupos não é um } \\
\text { fator de risco; mas os comportamentos } \\
\text { podem ser. A utilização do termo "grupo } \\
\text { de alto risco" pode criar um falso senso de } \\
\text { segurança entre pessoas que têm } \\
\text { comportamentos de risco, mas não se } \\
\text { identificam com tais grupos, além de } \\
\text { poder aumentar o estigma e a } \\
\text { discriminação contra determinados } \\
\text { grupos }\end{array}$ & $\begin{array}{l}\text { Populações-chave } \\
\text { Este termo é preferível } \\
\text { porque destaca que estas } \\
\text { populações são chave para } \\
\text { a dinâmica da epidemia ou } \\
\text { chave para a resposta do } \\
\text { HIV } \\
\text { As populações-chave são } \\
\text { diferentes de populações } \\
\text { vulneráveis. Estas últimas } \\
\text { estão sujeitas a pressões da } \\
\text { sociedade ou a } \\
\text { circunstâncias sociais que } \\
\text { podem torná-las mais } \\
\text { vulneráveis à exposição ao } \\
\text { HIV e outras infecções }\end{array}$ \\
\hline HIV/AIDS; HIV e AIDS $^{54}$ & $\begin{array}{l}\text { Para evitar equívocos entre dois conceitos } \\
\text { diferentes, evitamos usar a expressão } \\
\text { HIV/AIDS. A maioria das pessoas } \\
\text { vivendo com HIV não tem AIDS }\end{array}$ & $\begin{array}{l}\text { Pessoas vivendo com HIV, } \\
\text { prevalência do HIV, } \\
\text { resposta ao HIV, testagem } \\
\text { para HIV, doença } \\
\text { relacionada ao HIV, }\end{array}$ \\
\hline
\end{tabular}

${ }^{54}$ É importante destacar que muitos autores citados ao longo dessa dissertação utilizaram-se desse termo para se referir ao HIV e a Aids. Entretanto, por escolha também política, preferi escrever "o HIV e a Aids" quando quis me referir à infecção e ao estado clínico da Aids, ou separá-los na tentativa de precisar a qual eu me referia. Não alterei as citações originais. 


\begin{tabular}{|c|c|c|}
\hline & $\begin{array}{l}\text { A expressão "prevenção do HIV/AIDS" é } \\
\text { incorreta porque a prevenção do HIV } \\
\text { envolve o uso correto e constante do } \\
\text { preservativo, o uso de agulhas e } \\
\text { equipamentos esterilizados, mudanças em } \\
\text { normas sociais por diante, enquanto a } \\
\text { prevenção da AIDS envolve a terapia } \\
\text { antirretroviral, antibióticos } \\
\text { antifúngicos, nutrição adequada, } \\
\text { profilaxia para prevenção da tuberculose, } \\
\text { etc. }\end{array}$ & $\begin{array}{l}\text { diagnóstico de AIDS, } \\
\text { crianças vulnerabilizadas } \\
\text { pela AIDS }\end{array}$ \\
\hline $\begin{array}{l}\text { Infectado com AIDS; infectado } \\
\text { com HIV; transmissores }\end{array}$ & $\begin{array}{l}\text { Ninguém é infectado com AIDS; a AIDS } \\
\text { não é um agente infeccioso }\end{array}$ & $\begin{array}{l}\text { Pessoa vivendo com HIV; } \\
\text { pessoa HIV positiva; } \\
\text { pessoa de sorologia } \\
\text { desconhecida para o HIV } \\
\text { (se este for o caso) }\end{array}$ \\
\hline $\begin{array}{l}\text { Luta e outras expressões que } \\
\text { denotem o combate (ex: batalha, } \\
\text { campanha ou guerra) }\end{array}$ & $\begin{array}{l}\text { Para evitarmos a transferência de luta } \\
\text { contra o HIV para uma luta contra pessoas } \\
\text { vivendo com HIV, evitamos estes termos }\end{array}$ & $\begin{array}{l}\text { Resposta, manejo, medidas } \\
\text { contra, iniciativa, ação, } \\
\text { esforços e programa }\end{array}$ \\
\hline Pandemia & $\begin{array}{l}\text { Uma epidemia que se dissemina em } \\
\text { regiões inteiras, continentes ou até no } \\
\text { mundo inteiro, às vezes, é chamada de } \\
\text { pandemia. Contudo, o termo é impreciso }\end{array}$ & $\begin{array}{l}\text { Epidemia } \\
\text { Especifique a dimensão em } \\
\text { questão: local, nacional, } \\
\text { regional ou global }\end{array}$ \\
\hline $\begin{array}{l}\text { Pessoas vivendo com AIDS, } \\
\text { PVHA, PVHIV, pacientes de } \\
\text { AIDS, pessoa que sofre de AIDS } \\
\text { ou vítimas }\end{array}$ & $\begin{array}{l}\text { Referir-se às pessoas vivendo com HIV } \\
\text { como vítimas inocentes ou vítimas } \\
\text { implica, de maneira errônea, que as } \\
\text { pessoas que contraem o HIV de outras } \\
\text { maneiras merecem ser castigadas de } \\
\text { alguma forma }\end{array}$ & $\begin{array}{l}\text { Pessoas vivendo com HIV } \\
\text { ou criança vivendo com } \\
\text { HIV } \\
\text { Estes termos refletem o fato } \\
\text { de que as pessoas com HIV } \\
\text { podem continuar a viver } \\
\text { bem e de forma produtiva } \\
\text { por muitos anos } \\
\text { Pessoas convivendo com } \\
\text { HIV } \\
\text { O termo engloba familiares } \\
\text { e dependentes que podem } \\
\text { estar envolvidos com os } \\
\text { cuidados à pessoa vivendo } \\
\text { com HIV ou afetado de } \\
\text { outra maneira pelo HIV }\end{array}$ \\
\hline Portador de AIDS & $\begin{array}{l}\text { Não se utiliza este termo porque é } \\
\text { incorreto, estigmatizante e ofensivo para } \\
\text { muitas pessoas vivendo com HIV }\end{array}$ & Pessoa vivendo com HIV \\
\hline Risco de AIDS & $\begin{array}{l}\text { Recomenda-se não utilizar este termo, } \\
\text { salvo para se referir a comportamentos ou } \\
\text { condições que aumentem o risco da } \\
\text { evolução da síndrome em pessoas HIV } \\
\text { positivas }\end{array}$ & $\begin{array}{l}\text { Risco de contrair HIV; } \\
\text { risco de exposição ao HIV }\end{array}$ \\
\hline Sexo seguro & $\begin{array}{l}\text { Este termo pode implicar segurança total. } \\
\text { O termo sexo mais seguro reflete com } \\
\text { maior precisão a ideia de que escolhas } \\
\text { podem ser feitas e comportamentos } \\
\text { podem ser adotados para reduzir ou } \\
\text { minimizar o risco de contrair ou transmitir } \\
\text { o HIV. As estratégias de sexo mais seguro } \\
\text { incluem o sexo sem penetração, o uso } \\
\text { correto e contínuo de preservativos }\end{array}$ & Sexo mais seguro \\
\hline
\end{tabular}




\begin{tabular}{|c|c|c|}
\hline & $\begin{array}{l}\text { masculinos ou femininos, a redução do } \\
\text { número de parceiros sexuais, a utilização } \\
\text { de outros métodos da prevenção } \\
\text { combinada }\end{array}$ & \\
\hline Teste de AIDS & $\begin{array}{l}\text { Não existe teste de AIDS. O teste é de } \\
\text { HIV } \\
\text { O teste sorológico anti-HIV baseia-se na } \\
\text { detecção de anticorpos para HIV } \\
\text { presentes ou não na amostra do paciente }\end{array}$ & $\begin{array}{l}\text { Teste de HIV; teste } \\
\text { sorológico anti-HIV }\end{array}$ \\
\hline $\begin{array}{l}\text { Viciados em drogas; pessoas que } \\
\text { abusam de drogas; drogado; } \\
\text { drogadito }\end{array}$ & $\begin{array}{l}\text { São termos depreciativos que não } \\
\text { contribuem para promover a confiança e } \\
\text { o respeito necessários no trabalho com } \\
\text { pessoas que usam drogas }\end{array}$ & Pessoas que usam drogas \\
\hline Usuários de drogas intravenosas & $\begin{array}{l}\text { Este termo é incorreto porque as drogas } \\
\text { também podem ser injetadas de forma } \\
\text { subcutânea e intramuscular. Não se deve } \\
\text { referir às pessoas como uma abreviação, } \\
\text { como UDI (usuários de drogas injetáveis), } \\
\text { porque desumaniza o indivíduo. O nome } \\
\text { ou a identidade do grupo deve ser escrito } \\
\text { por extenso }\end{array}$ & $\begin{array}{l}\text { Pessoas que usam drogas } \\
\text { injetáveis } \\
\text { Estes termos são } \\
\text { preferíveis porque colocam } \\
\text { ênfase nas pessoas }\end{array}$ \\
\hline Vírus da AIDS; vírus do HIV & $\begin{array}{l}\text { A AIDS é uma síndrome clínica, portanto } \\
\text { é incorreto se referir ao HIV como vírus } \\
\text { da AIDS } \\
\text { A utilização do termo "vírus do HIV" é } \\
\text { redundante, pois a sigla HIV significa } \\
\text { Vírus da Imunodeficiência Humana }\end{array}$ & $\begin{array}{l}\text { HIV } \\
\text { Não há necessidade de } \\
\text { definir ou de acrescentar a } \\
\text { palavra "vírus" }\end{array}$ \\
\hline
\end{tabular}

Fonte: Elaboração do autor a partir de UNAIDS, 2017, p. 29-33.

As contranarrativas são processos individuais e coletivos de ressignificação de narrativas em busca da construção de uma nova realidade narrativa. Além dos termos elencados pelo Guia de Terminologias, é importante ressaltar que alguns termos estigmatizantes também são construídos a partir de figuras de linguagem, a exemplo da metáfora e da metonímia. Repensar nosso vocabulário quando nos referirmos ao HIV e à Aids é nos propor a participar da ressignificação das narrativas do HIV e da Aids e nos impulsionar a compartilhar e defender essa perspectiva. Somos nós também os responsáveis por lidar com esse compartilhamento contranarrativo quando nos depararmos com narrativas estigmatizantes. Não é para impormos uma verdade, senão levar às pessoas ao nosso redor a uma reflexão sobre o impacto de continuar a espalhar que "HIV é morte", que se trata de uma "peste gay" ou, ainda, que se está livre de infectar-se por não pertencer a um "grupo de risco". Por fim, é importante que eu diga que as contranarrativas são produto de um longo processo de ressignificação. Nessa seção, eu quis trazer à discussão a importância das redes sociais e o seu papel no 
compartilhamento e na construção das contranarrativas entre as pessoas que vivem com HIV.

\section{3}

Tecendo Contranarrativas: Sujeitos que Ressignificam o HIV e a Aids

Ressignificar o HIV e a Aids não é minimizar a preocupação com o vírus e com o estado clínico porque existem meios eficazes de prevenção e tratamento antirretroviral que permitem o controle da multiplicação do vírus. Ressignificar não é deixar de tomar medidas preventivas para evitar o contato com o HIV e de tratamento após o contato com o HIV. Ressignificar é, antes de tudo, desfazer os efeitos de fronteira gerados pelas narrativas do HIV e da Aids. As narrativas criadas e geradas nos anos 1980 e 1990 persistem. Ressignificar nos permite decidir como queremos contar essa história de agora em diante, sem desprezar ou minimizar as consequências da infecção, mas considerar que, antes de tudo, as narrativas continuam a persistir sobre corpos específicos e ajudam a criar a barreira de distanciamento ou de aproximação sobre essas pessoas. Ressignificar é incorporar as contranarrativas e permitir com que elas ajam sobre nossa linguagem, sobre nossas ações, sobre nossos afetos, sobre nossos corpos e nos impulsione a replicálas a cada novo encontro propício que tivermos em nossos caminhos. Ressignificar é enfrentar as narrativas diante de nós. Ressignificar é acolher. Ressignificar é a alteridade. Ressignificar é urgente.

Um dos caminhos adotados para ressignificar o HIV e a Aids é buscar por comunidades em redes sociais, além da leitura de blogs, acompanhamento de vídeos no Youtube, personalidades no Instagram, conversas com pessoas que vivem com HIV, acolhida em Postos de Saúde ou durante campanhas preventivas, enfim, diversos são os lugares - tanto online quanto offline - para se entender melhor sobre a infecção e, consequentemente, entrar em contato com as contranarrativas.

Além das expressões autobiográficas compartilhadas em blogs ou redes sociais (TIMERMAN e MAGALHÃES, 2015; DUARTE, 2017; DAMASCENO, 2019), é possível encontrar algumas menções referentes às narrativas ficcionais como possibilidade de compartilhar histórias sobre viver com HIV, mantendo ainda o sigilo de sua identidade e, ao mesmo, expressando seus afetos em palavras 
alcançáveis (KIND, 2017, p. 1055). É necessário que essas narrativas ficcionais, assim como a manifestação em Blogs (TIMERMAN e MAGALHÃES, 2015), façam sentido também, porque "a narrativa não é só uma listagem de acontecimentos, mas uma tentativa de ligá-los tanto no tempo, como no sentido" (JOVCHELOVITCH e BAUER, 2007, p. 92 apud KIND, 2017, p. 1055). As tentativas de contar uma história, principalmente aquelas envolvidas em constituírem momentos autobiográficos, são vistas como vozes que falam tanto da sociedade e da cultura em que elas são produzidas quanto do próprio sujeito ou do grupo, porque uma história individual nem sempre é fruto da individualidade (KIND, 2017).

Artur Timerman e Naiara Magalhães (2015) constroem um livro sobre com as histórias da Aids. São textos técnicos e autobiográficos dos autores, principalmente porque, no caso de Artur Timerman, ele esteve na linha de frente da epidemia de Aids no início da década de 1980 no Brasil. Conhecemos um pouco mais dessas histórias autobiográficas no documentário "Carta para Além dos Muros" (2019), em que o médico escritor compartilha suas lembranças e seus afetos em alguns trechos. Apesar de o livro conter informações relevantes sobre a história do HIV e da Aids, principalmente no que se refere à existência da Aids muito anterior ao conhecimento do vírus HIV separado em laboratório (TIMERMAN e MAGALHÃES, 2015), alguns relatos de pessoas que vivem com HIV trazem um panorama sobre como as contranarrativas se manifestam na individualidade da vida cotidiana. Uma vida que enfrenta, para além dos desafios de entendimento próprio sobre a infecção, as narrativas do HIV e da Aids em seus círculos sociais. É uma obra que revela como as pessoas que vivem com HIV lidam com as metáforas e metonímias das narrativas da infecção e como elas têm vontade e força para falar sobre seus afetos e suas emoções, principalmente quando se sentem sufocadas por essas narrativas. Percebo em seus relatos autobiográficos, e teço aqui nessa dissertação, como alguns desses personagens transformaram a manifestação afetiva provocada pelo HIV a partir de movimentos contranarrativos: seja a partir da escrita em blogs, com alcance maior na internet; em diários, com construções íntimas de reflexões sobre o HIV e sobre a Aids, sobre a sociedade e sobre si; em conversas, não esconder que se vive com HIV e tornar-se referência em seu círculo social quando alguém, ou algum conhecido, descobre seu status sorológico como positivo para HIV. O livro traz sujeitos que desmistificam a partir do próprio entendimento 
do mundo o que é viver com HIV e, de certa forma, contribuem com as contranarrativas do HIV e da Aids, pois permitiram que seus relatos pudessem compor uma obra e alcançar um público maior, talvez um público que ainda têm desconhecimento total sobre o que é o HIV e a Aids, ou que ainda não tem grande conhecimento sobre o assunto e busca aprender mais. É impossível descrever esse público, mas descrevo como esses relatos são importantes para as contranarrativas do HIV e da Aids.

Primeiro, precisamos compreender que as contranarrativas possuem diferentes tipos de alcance. Há aquelas privadas (DUARTE, 2017; DAMASCENO, 2019), restritas a uma comunidade virtual. Há aquelas que são comandadas pelo sistema de saúde e, aos poucos, buscam reformular o entendimento sobre a infecção e corrigir erros estigmatizantes do passado (PASSOS e BARROS, 2009). E há aquelas íntimas (TIMERMAN e MAGALHÃES, 2015), que se constroem por experiências pessoais e podem estar com todas as pessoas que vivem com HIV e com toda a sua comunidade afetiva. Nessas contranarrativas construídas pelas experiências individuais e singulares, percebe-se o descontentamento em descobrir as narrativas do HIV e da Aids e todo o processo de exclusão gerado por elas. Assim, esses relatos também constroem intimidade com os leitores e criam conexão com o que é relatado, porque trata-se de uma troca afetiva por meio das palavras (AHMED, 2014). Os sujeitos se expressam e eu, como pesquisador e escritor, sou impactado por ser leitor atento de suas escritas e por ser pesquisador ainda mais atento pela importância de suas escritas. Por isso teço essas narrativas nessa pesquisa, porque elas, de certa forma, apresentaram-me parte do que eu entendo como contranarrativas.

Um dos relatos que escolho é sobre Rafael, nome fictício, que ao receber o diagnóstico de Aids, quando os níveis os linfócitos CD4 no sangue estavam abaixo de 500, padrão desejável, sentiu a manifestação de seus afetos em seu corpo e genuína necessidade de escrever sobre o mal-estar sentido, tanto por causa do efeito da medicação, quanto das incertezas sociais trazidas pelas narrativas do HIV e da Aids. Rafael criou um blog intitulado "Diário de um jovem soropositivo", em que anotava todos os incômodos sentidos durante esse momento. Esse fato de nutrir um blog com distintos textos, principalmente com recortes de sua própria biografia, tornou um poderoso instrumento de entendimento sobre seus próprios afetos e emoções a partir da escrita e da compreensão do peso das narrativas do HIV e da 
Aids sobre a sua própria realidade social. O blog tornou-se um diário pessoal para tirar de sua individualidade a culpa colocada pelas narrativas ao mesmo tempo que ressignificava o que era viver com HIV. As narrativas que principalmente atingiam a Rafael eram metonímicas, ou seja, associavam instantaneamente o HIV à morte, a Aids à morte. A metáfora de que se tratava de uma "peste gay" ou que se conectava diretamente com os homossexuais não lhe atingiu, porque Rafael acreditava que "pegar HIV era uma realidade completamente distante. Não chegava a se apoiar no mito de que homens não são contaminados por mulheres, como muitos acreditam. Nem na falsa ideia de que só os homossexuais correm risco. Simplesmente não pensava no assunto" (TIMERMAN e MAGALHÃES, 2015, p. 15). Ou seja, as narrativas que o envolviam não eram metafóricas, senão metonímicas, como se percebe na descrição de seus relatos. Como introduzirá o documentário "Cartas para Além dos Muros" (2019), a prerrogativa "Precisamos Falar sobre Isso, é muito nítida nos relatos de Rafael, pois ele não pensava sobre o assunto. Porém, por mais específica seja essa descrição sobre as narrativas e as contranarrativas de Rafael, ele "se deu conta de que o mais complicado em ter HIV não é a doença ou o tratamento, mas sim o impacto que esse diminuto vírus tem sobre as relações" (TIMERMAN e MAGALHÃES, 2015, p. 15)

As relações de Rafael se referem às amorosas, de relacionamento e compromisso. Esse impacto sobre suas relações se construiu pela incerteza, desconhecimento e medo que sua companheira manifestava, pois, mesmo conversando com ginecologista, professores de medicina e terapeutas, ela não conseguiu manter a relação, mesmo sendo sorodiscordante. Timerman e Magalhães (2015) relatam como essa história continuou e terminou:

até que, por fim, enviou a ele um e-mail com o assunto 'Tristeza', em que explicava que não conseguiria se relacionar com o rapaz. Ele, então lhe respondeu: - Tudo bem... Mas vamos nos encontrar pra conversar, tomar um café? $\mathrm{E}$ a resposta que foi: Acho melhor não. Rafael conta o desfecho da história: - Ela sumiu e, depois de um mês, reapareceu. Fomos a uma festa, e ela me convidou pra continuar a noite na casa dela. Mas aí eu não quis mais. Fiquei machucado com a maneira como ela agiu, de nem querer me ver. E, dessa vez, ela me parecia estar agindo por impulso, porque estava pressionada pelas amigas, que queriam saber por que a gente tinha terminado, por que a gente não tinha transado. (TIMERMAN e MAGALHÃES, 2015, p. 15) 
Em visitas a infectologistas, Rafael foi entendendo melhor o que era viver com HIV com suas relações, um deles até se posicionou:

- Rafael, como médico de soropositivos há tantos anos, é natural que eu enxergue o lado dos meus pacientes. E o que eu vejo é que aqueles que começam a contar a todos podem sim vir a sofrer com isso. Amigos se afastam, relacionamentos tornamse mais difíceis. Há quem lide bem com isso. E há quem não lide bem com isso. O que precisa ficar mais claro é que, se você quer fazer isso, é por opção, e não por obrigação. A sua obrigação, como a de qualquer outra pessoa, soropositiva ou não, é se proteger e, para isso, a camisinha basta. (TIMERMAN e MAGALHÃES, 2015, p. 16)

As contranarrativas também são construídas a partir dos encontros entre as pessoas que vivem com HIV e seus infectologistas. É a experiência desse profissional que é transmitida ao paciente, uma visão própria do mundo contribuída por diversas visões de outras pessoas que vivem com HIV. É um compartilhamento íntimo em um consultório capaz de aquietar afetos tristes. Como conclusão do relato de Rafael, Timerman e Magalhães (2015) colocam:

\begin{abstract}
Se, no início, o HIV se tornou o assunto central de sua vida, tomando boa parte de seu tempo, sua energia e seus pensamentos - sobretudo pelo sofrimento imposto pelos primeiros remédios , hoje assumiu proporções mais reais. Uma boa medida disso é seu blog, que no princípio recebia atualizações diárias e agora vem sendo 'alimentado' com mais parcimônia. Rafael estuda encerrá-lo. - A 'vida normal' está de volta. Mas aprendi também que ela sempre esteve aqui. Vida é assim mesmo: sempre tem um obstáculo. (TIMERMAN e MAGALHÃES, 2015, p. 17)
\end{abstract}

A partir do relato de Rafael, é possível compreender como a escrita lhe foi importante na construção de suas próprias contranarrativas, na expressão de seus afetos e suas emoções pelos momentos mais duros que enfrentou e que não compreendia muito bem. Desenhar suas palavras em um blog para engajar nas suas relações com outros e com si próprio é a expressão individual das contranarrativas, que precisam ser manifestadas e aquiescidas no sujeito e dialogar com todo o processo desencadeado com o encontro com o HIV e com as suas narrativas. A escrita autobiográfica para Rafael, traduzida também em seu interesse em cultivar um blog, marcou uma peça importante das contranarrativas, a expansão, em rede online, de sua vivência com HIV com efeitos desejados também de alcançar outras pessoas inquietas pelo encontro com as narrativas do HIV e da Aids. 
Além de Rafael, outra personagem importante das histórias tecidas por Timerman e Magalhães (2015) é a história de Flor. Uma mulher, de cidade pequena, com dificuldade de lidar com o vírus HIV, principalmente porque tem medo de ser descoberta enquanto busca remédios nos postos de saúde. A manifestação de afetos, traduzidos por emoções, a exemplo de tensão e medo, é relatada durante a entrevista porque eles sempre se manifestam nesse momento em que deve buscar os remédios. Paira a tensão de encontrar alguém conhecido. E existe justificativa para essa manifestação, "em duas ocasiões, isso aconteceu, de fato. Numa delas, como ainda não tinha sido vista, aguardou do lado de fora; na outra, precisou inventar uma desculpa" (TIMERMAN e MAGALHÃES, 2015, p. 26). Esse constante medo em ser descoberta, é explicado na percepção dela:

- Piora o drama do 'falar ou não falar'? De repente, eu conto para a pessoa, ela vai querer desabafar com alguém, daí desse alguém vai para outro alguém, e assim por diante. Então, se eu começo a me precipitar e a contar pra gente que não é de extrema confiança, daqui a pouco a cidade inteira está sabendo. E aí, em qualquer lugar que eu for, o HIV vai chegar antes de mim. Eu não vou mais ser a Flor, vou ser a 'soropositiva'. (TIMERMAN e MAGALHÃES, 2015, p. 26)

Flor não quer ser a encarnação das narrativas do HIV e da Aids, porque as narrativas são corrosivas e destroem os corpos, preenchem de afetos tristes e traduzem emoções depreciativas com si próprio. As contranarrativas deveriam repensar esse papel e tornar natural entender que o HIV está presente na sociedade e que as pessoas que vivem HIV possuem uma vida normal, embora estejam sempre propícias a tropeçar nas narrativas do HIV e da Aids e de encontrar pessoas dispostas a manifestar preconceitos e estigmas. Assim como Rafael,

uma maneira que Flor encontrou para lidar com suas aflições foi escrever anonimamente num blog. Em seus textos, bota para fora o que estiver lhe incomodando e, assim, alivia o pensamento dos problemas. O blog chama-se Drama da Flor, numa referência ao codinome adotado pela moça para tratar dos assuntos referentes ao HIV sem expor sua identidade. (TIMERMAN e MAGALHÃES, 2015, p. 28)

Preciso ressaltar que tanto o blog de Rafael quanto o blog de Flor não possuem mais domínio disponível para consulta. Tornaram-se importantes, na existência online, na época em que blogs eram bem difundidos como conectividade 
social. Mas sempre serão importantes para seus criadores, porque eles constituíram momentos de autodescoberta e de criação e de fortalecimento das contranarrativas do HIV e da Aids, e serviram de apoio a outras pessoas que recorreram, em algum momento, à internet para entender melhor o efeito do HIV e da Aids sobre os corpos e sobre a sociedade e se encontraram com dois blogs de personalidades diferentes, repletos de textos escritos ao longo de um tempo de descobertas pessoais. Os blogs, embora possam pareçam insignificante para uma sociedade totalmente desconectada com o gênero blog como conectividade social, já se constituíram como fontes de contranarrativas.

Marcio, outro personagem abordado nos recortes de Timerman e Magalhães (2015), ressignifica as narrativas do HIV e da Aids de uma forma totalmente diferente da de Rafael e Flor. Ele se tornou um símbolo dentro de seu círculo de amizades de resiliência ao assumir, mesmo percebendo os efeitos estigmatizantes das narrativas do HIV e da Aids no seio social, o HIV publicamente com seus contatos próximos. Apesar de não ser empecilho algum para Marcio, e que não deveria ser para ninguém, assumir o HIV ou ser submetido a um exame sigiloso em local de trabalho pode influir na vida profissional. Descobriu o HIV a partir de um exame,

o diagnóstico, realizado em 1989, quando ele tinha 27 anos de idade, foi involuntário. A empresa em que trabalhava submeteu todos os funcionários a um check-up sem informá-los de que o exame de HIV seria incluído. Diante do resultado positivo de Marcio, a empresa o orientou a procurar cuidados médicos. Vinte dias depois, ele foi demitido por telefone. (TIMERMAN e MAGALHÃES, 2015, p. 37)

É importante reforçar que o Ministério do Trabalho pró́be que as companhias "submetam seus funcionários ao teste de HIV de forma obrigatória, seja na admissão, seja em qualquer outro momento" (TIMERMAN e MAGALHÃES, 2015, p. 37). Quem vive com HIV não possui nenhuma obrigação de revelar. E jamais deve ser submetida ou ser pressionada a falar sobre isso. O que se deve fazer, ao invés de forçar alguém a informar o status sorológico, é tornar a sociedade acolhedora, em suas narrativas e em suas práticas, com as pessoas que vivem com HIV. 
Da força das contranarrativas construídas a partir de Marcio, observa-se que assumir que vive com HIV o fez um ponto seguro para explicar e acolher pessoas que recentemente descobrem que vivem com HIV. Ele se tornou uma referência, e

de tempos em tempos, ele recebe uma ligação do tipo: - Eu sei que você nem me conhece direito, mas eu estou te ligando porque o meu amigo fulano falou que você pode me ajudar. É quando se vê na situação de usar a própria experiência para ajudar alguém que acabou de receber o diagnóstico de HIV-positivo. Nessas situações, costuma marcar uma conversa para acalmar a pessoa e orientá-la quanto aos cuidados que precisa tomar. - As pessoas ainda chegam a mim bem assustadas. Não sabem nem o que perguntar. Mais ou menos elas sabem que existe remédio, mas o impacto da notícia ainda está no campo do emocional. Geralmente, falam pra mim: 'Eu tô assustado, não sei o que fazer...'. Ou, muitas vezes, dizem simplesmente: 'Me fala que vai dar tudo certo'. Aí eu respondo: 'Vai dar tudo certo, se você quiser que dê certo'. Se a pessoa coloca isso na cabeça, faz o que tem que ser feito: agradece que existe uma medicação eficiente pra controlar o vírus, toma os remedinhos todos os dias e segue a vida. Por outro lado, tem gente que entra numa fase de rejeição e paranoia tão longa - a pessoa se afasta de todo mundo, perde a fome, não dorme... Aí começa a ficar doente mesmo. Conheço um rapaz, ex-namorado de um amigo, que, aos 24 anos, descobriu que estava com HIV e, em quatro meses, morreu. Deitou na cama e ficou esperando. Eu até tentei conversar com ele, mas percebi claramente que ele não ouvia o que eu falava. Já tinha feito a escolha dele. Pra muita gente, remédio é uma coisa invasiva demais. 'Pô, eu vou viver tomando remédio?', a pessoa pensa. Claro que ninguém gosta de ser dependente de medicamento nenhum, mas, pra mim, isso não é algo de outro mundo. Tomo os meus comprimidos diariamente, como a minha mãe toma o remédio dela pra hipertensão. (TIMERMAN e MAGALHÃES, 2015, p. 38)

Marcio se tornou ponto de apoio às pessoas que lhe procuravam. Uma comunidade de pessoas que descobrem que vivem com HIV e não aceitam o efeito das narrativas do HIV e da Aids e buscam por explicações outras. Marcio mostrava que sua experiência, não só vivendo com HIV, como também a experiência construída a partir das experiências compartilhadas pelas pessoas que já o procuraram, forneceu-lhe chaves para expandir suas próprias versões das contranarrativas. Mostrou que HIV não é morte, principalmente quando a pessoa está determinada a seguir com o tratamento. E mostrou-se também como um ponto de apoio, capaz de ser replicado, um dia, pelas pessoas que o procuraram quando se depararam com as narrativas do HIV e da Aids. 
As contranarrativas se originam em distintas manifestações. Para além daquelas cultivadas em redes sociais, dos textos publicados em blogs ou em determinadas figuras que se mostram abertas a trocar experiências e conversar sobre o HIV, escolhi um documentário que sintetiza as narrativas do HIV e da Aids e nos fornece novas indagações acerca das contranarrativas, principalmente sobre sua produção e manifestação.

O documentário "Carta para Além dos Muros" (2019), dirigido por André Canto, revela em um diálogo com a sociedade as narrativas do HIV e da Aids. Com diversos integrantes de movimentos sociais ligados à Aids, médicos infectologistas e dermatologistas, jornalistas e escritores, para citar alguns, a narrativa é tecida por eles a partir da experiência própria, dos relatos autobiográficos, com a infecção e com o estado clínico provocado pela Aids. Não se trata de um documentário totalmente voltado à construção de contranarrativas da infecção, senão uma apresentação das narrativas e, a partir da narrativa autobiográfica, o tecimento das contranarrativas e das duras críticas aos efeitos de exclusão e distanciamento dos corpos que vivem com HIV. O título "Carta para Além dos Muros" é referente às cartas escritas por Caio Fernando Abreu, enquanto internado em um hospital, que conferia "à linguagem o potencial libertador da escritura que a cama de hospital e o muro não possibilitavam ao corpo que a aqueles se circunscrevem, ainda que ao corpo que [se] escreve lhe doa escrever" (INÁCIO, 2016, p. 490-491).

As narrativas são construídas cronologicamente, desde um momento préepidêmico até o ano de 2019, momento de estreia do documentário. Desde essa época, até o meu presente - o momento em que escrevo essas palavras no ano de 2021 - as narrativas se construíram e persistiram por novos atores, florescendo novas pessoas dispostas a manifestar as contranarrativas do HIV e da Aids. Grande parte da discussão do documentário se complementa com o segundo capítulo de minha dissertação. O documentário se apresenta mais como uma exposição das narrativas do HIV e da Aids, com a inclusão de testemunhas desse momento de surgimento e de ascensão da infecção no país, e desses relatos autobiográficos percebem-se construções de contranarrativas a partir da desmistificação dos grupos de risco, das metáforas e metonímias envolvidas no processo narrativo da infecção, além do esforço de ressignificar as palavras e desestigmatizar os corpos.

Muitos dos relatos autobiográficos apresentavam elementos comuns: amigos que se foram em decorrência de infecções oportunistas. Tornava-se, como foi relato 
algumas vezes no documentário com palavras diferentes, impensável que estivessem preparados para se familiarizar com a rotina da morte. Adaptar-se com a rotina da morte não apenas física, como também a morte social, porque o HIV sempre acompanhou círculos de exclusão (CARTA PARA ALÉM DOS MUROS, 2019).

Percebo que o documentário traz um olhar totalmente diferente sobre a pessoa que vive com HIV. Alguns elementos são captados desde o início: ruas e avenidas de São Paulo (SP) representando a vida cotidiana com pessoas, carros, prédios. Essa imagem construída apresenta a realidade e a normalidade da vida da pessoa que vive com HIV. Essa construção de um dia normal em São Paulo (SP) se contrapõe totalmente à imagem de uma das primeiras reportagens do Fantástico, no dia 27 de março de 1983, incluídas no documentário, sobre o surgimento da Aids. Dessa reportagem, percebem-se músicas de suspense, imagens hospitalares, ruídos de monitores nos quartos e uma narração de reportagem em tom investigativo. Esse contraste gritante de imagens mostra duas imagens diferentes construídas sobre os corpos que vivem com HIV. Os trechos de reportagens jornalísticas ao longo do documentário revelam uma fronteira de exclusão e afastamento com essas pessoas. Enquanto o documentário, por apresentar a vida cotidiana, revela um antagonismo àquela época. Agora veem-se rostos, tocam-se neles, e eles sorriem, envelhecem, choram e estampam a realidade de uma vida em metrópole.

José Silvério Trevisan, escritor, é uma das pessoas entrevistadas para comentar como o fenômeno midiático da Aids no Brasil começou a ser noticiado. Com referência aos Estados Unidos e às narrativas transnacionais, primeiro lugar de aumento dos casos de Aids no mundo e o lugar que forjou a definição dos 5Hs, relata que muito das notícias divulgadas na mídia nacional eram influenciadas pela mídia estadunidense e não havia ineditismo em relação ao caráter das narrativas do HIV e da Aids. Em um trecho de sua fala, Trevisan ressalta "eu estava aterrorizado... Aterrorizado não é a palavra... Eu estava chocado com o nível de grosseria de como o tema estava sendo tratado" (CARTA PARA ALÉM DOS MUROS, 2019). É interessante perceber que, como descrito na seção de afetos e emoções desse trabalho, temos dificuldade de escolher palavras para expressar adequadamente nossos afetos porque não temos a certeza de quais serão mais capazes de capturar aquilo que sentimos (GILBERT, 2013; AHMED, 2014). Na busca por compreender qual era a melhor palavra que pudesse traduzir seus afetos 
em emoção, Trevisan encontra a palavra aterrorizado. Como escritores, sabemos o significado e o peso das palavras em nossas vidas. Estar aterrorizado pelo contato com as narrativas do HIV e da Aids pode servir de impulso à produção das contranarrativas, à compreensão de que essas narrativas estigmatizantes não deveriam prevalecer sobre a sociedade.

É importante compreender que as contranarrativas também surgem paralelas ao aparecimento das narrativas do HIV e da Aids. Encabeçadas principalmente pelos movimentos LGBTQIA+, lutava-se por reconhecimento e por assistência sanitária. Artur Kalichman, médico sanitarista, entrevistado durante o documentário, ressalta que

\begin{abstract}
o começo do movimento social se contrapondo a Aids vem muito do movimento gay, do movimento gay americano, acaba dando origem à ONGs mais voltadas para Aids, quanto lá quanto aqui [...]. O primeiro programa de Aids foi no Estado de São Paulo, e foi uma resposta à comunidade gay que estava preocupada porque estava atingindo ela diretamente. (CARTA PARA ALÉM DOS MUROS, 2019)
\end{abstract}

As contranarrativas começaram desde cedo a serem exigidas pelos movimentos LGBTQIA+, pois queria-se apagar uma culpa inexistente sobre a comunidade e sobre os corpos. Trata-se, inclusive, de uma luta contra o tempo para ressignificar essa infecção. Mas a cada nova reportagem e a cada novo passo da epidemia, tornou-se mais difícil para expandir as contranarrativas (BARATA, 2006). Nessa época, grupos sociais, principalmente aqueles ligados à comunidade LGBTQIA+ e uma parcela da classe médica, tentavam combater o preconceito e o estigma do HIV e da Aids, principalmente porque combater esse estigma era combater o estigma contra os homossexuais. Tornava-se quase uma construção metonímica: associar o estigma da Aids ao estigma dos homossexuais. Tudo isso em um cenário onde pairava o misticismo envolvendo uma doença fatal (CARTA PARA ALÉM DOS MUROS, 2019).

Por isso, também ressalto a relevância de pensarmos que as contranarrativas são movimentos tão velhos quanto às primeiras marcas estigmatizantes provocadas pela interpretação do HIV nos corpos humanos. Precisamos entender que as contranarrativas surgem também do momento de exposição das próprias narrativas. O documentário é fruto dessa exposição. Conhecer as narrativas do HIV e da Aids e ouvir algumas vozes que interpretam autobiografias próprias é um impulso à 
reflexão. Refletimos também a partir do momento em que somos induzidos por um viés, nesse caso, somos induzidos a compreender como as narrativas do HIV e da Aids corroeram e corroem vidas. A reflexão que nos é esperada desse momento de exposição implica expandirmos as contranarrativas em nossas vidas. Por suposto, o termo que cunho aqui, contranarrativas, não é dito ou descrito ao longo do documentário, porque esse deveria ser um movimento natural de reflexão de ressignificação. Os afetos manifestados em mim ao longo do documentário guiaram-me a essa reflexão e a esse reforço narrativo: as contranarrativas nos são apresentadas e cabe a nós expandi-las a partir de nossas vidas ou silenciá-las por um silenciamento forçado. Um silenciamento que se escolhe fazer por determinações próprias ou mais cômodas.

Outra indagação que me afeta a partir da exibição do documentário é sobre a contextualização. Penso nesse assunto de uma forma que também não me exclua dessa pergunta, porque também construí da forma que achei mais apropriada para a pesquisa. É necessário sempre contextualizarmos as narrativas do HIV e da Aids, mesmo quando nosso foco é ressignificar a infecção por meio de suas narrativas? Trata-se de um silêncio que não consigo preencher muito bem. O documentário, assim como minha pesquisa, contextualizou as narrativas do HIV e da Aids antes de começar a abordar a urgência de desestigmatizar a infecção. Teríamos o mesmo efeito de acolhimento social se simplesmente colocássemos em exposição às novas gerações e às gerações já cientes da questão do HIV as contranarrativas sem contextualizá-las por sua origem? Dessa forma, não precisaríamos explicar as metáforas e as metonímias, nem mesmo manter vivo em nós mesmos as narrativas internalizadas do HIV e da Aids. Ao invés de falarmos que se tratou de uma "peste gay", falaríamos que a infecção não possui rosto e a melhor forma de erradicar o HIV e a Aids do mundo é a partir da prevenção e tratamento. É importante manter presente que um dia a Aids foi considerada "peste gay" e todas as outras atrocidades estigmatizantes que impuseram na sociedade a separação entre grupos? A maneira de nos relacionarmos com a infecção mudou?

São perguntas que não possuo respostas suficientemente robustas para colocá-las em minha dissertação, mas, de toda forma, inserem-se em minha agenda de pesquisa. O que me cabe explicar e argumentar é que, independentemente dos caminhos adotados, - contextualização das narrativas para a manifestação das contranarrativas ou apenas a construção das contranarrativas sem contextualização 
alguma que possa reviver afetos tristes - é urgente falar sobre isso. No fim do documentário, levanta-se uma hashtag, \#PrecisamosFalarSobreIsso, para mover as contranarrativas nos círculos sociais dos telespectadores. Tratou-se sempre de que o HIV e a Aids acompanhava círculos de exclusão na sociedade, como reforçou o cantor e youtuber Gabriel Estrela. Esse fato reforça a importância de movimentos sociais LGBTQIA+ na luta por saúde e ressignificação, porque seus corpos são importantes e merecem atendimento de saúde de qualidade. Além disso, ele nos indaga: por que se vigia tanto o corpo que vive com HIV? (CARTA PARA ALÉM DOS MUROS, 2019). A pergunta colocada por Gabriel Estrela ainda nos mostra como é inesgotável compreender as narrativas e contranarrativas do HIV e da Aids, principalmente porque as perspectivas pelas quais nos apoiamos para entender o mundo são diferentes.

\section{4 \\ Conclusão}

As contranarrativas surgem da não aceitação das narrativas do HIV e da Aids. Surgem como movimento de contestação. Todo processo de ressignificação, e de construção de significados outros, não parte somente da individualidade. É um movimento coletivo de ressignificar um passado estigmatizante de uma epidemia. Devemos ficar atentos ao nosso redor e perceber como o HIV e a Aids são narrados. Se a persistência desse passado aparecer, talvez caiba a nós propormos uma nova reflexão sobre a epidemia e desfazer os efeitos de fronteiras que apartam. Não é uma tarefa fácil. Tornar-se agente do movimento de contranarrativas nos propõe muitos desafios, principalmente se abraçamos a causa para nossas vidas.

Identificar os elementos de uma narrativa - principalmente os elementos enraizados na estigmatização - é o ponto central para ressignificar uma narrativa. Fala-se de homossexualidade, mas não se fala de práticas vulneráveis independente da sexualidade. As narrativas escondem e colocam determinadas pessoas nos holofotes da epidemia, sem se atentar às práticas. As contranarrativas procuram direcionar os holofotes aos verdadeiros vetores da infecção, sem reforçar a ideia de que o HIV e a Aids possuem um rosto. Embora as narrativas estivessem centralizadas e estampadas nos noticiários, as contranarrativas estão 
descentralizadas. São focos de contranarrativas que emergem e impactam as pessoas dentro do alcance possível. A descentralização se ilustra em grupos do Facebook, em blogs, em contas do Instagram e do Twitter, em obras literárias e cinematográficas. Não sei como mensurar o alcance e nem sei se isso é possível. As contranarrativas, mesmo descentralizadas, impulsionam a ressignificação e estão presentes nas instituições. A UNAIDS, a maior referência do combate à epidemia de HIV, coloca em prática o projeto de ressignificar a epidemia e conceber os impactos da estigmatização das narrativas.

As contranarrativas, aos poucos, ganham espaço e excluem as narrativas do HIV e da Aids como modo explicativo da infecção. Embora o processo ainda seja lento, ele é constante. Talvez toda constância provoque resultados emblemáticos na sociedade, por mais tardio que esse resultado possa aparecer. É o sujeito, individual e coletivo, na ação de ressignificar que transforma o que se quer narrar sobre o HIV e sobre a Aids. As fronteiras são ressignificadas e passam a acolher. Pelos caminhos que eu for passar, trago comigo a certeza de que ressignificar é preciso. E incluir é urgente. 


\section{5}

\section{Considerações Finais}

Se começar era desafiador, apresentar minhas considerações finais nem deveria ser um obstáculo. Mas é esse o momento que eu preciso enxugar a minha escrita e minhas reflexões ao longo de muito tempo em cima de minha pesquisa e lhes mostrar pontos concisos e objetivos. Para que essa conclusão não se torne um ensaio, apresento cinco tópicos para me guiar e guiar-lhes por essa curta leitura. A primeira reflexão se pautará na minha escrita e como as metodologias abordadas por mim contribuíram para a construção dessa pesquisa e como eu as vejo desafiadoras como metodologias possíveis. A segunda reflexão se constrói sobre o antagonismo, não tão antagônico assim, das narrativas e das contranarrativas. A terceira reflexão se baseia na questão do HIV e da Aids sobre as fronteiras construídas sobre os corpos e como a economia afetiva rebuliça a vida das pessoas que vivem com HIV e de suas comunidades afetivas. A quarta reflexão é sobre o processo de ressignificação das epidemias narrativas do HIV e da Aids e qual deveria ser o nosso papel nesse processo de reproduzir significados outros. A quinta reflexão é sobre possíveis caminhos futuros que essa pesquisa poderá se desenvolver, é sobre reflexões íntimas com os leitores porque toda a dissertação foi construída a partir de minha intimidade com as palavras e com a construção da pesquisa.

Foi desafiador propor uma reflexão a partir da primeira pessoa. Falhei muitas vezes. Porém, compreendi que quando nos propomos a nos expressarmos em primeira pessoa em um trabalho acadêmico não estamos nos propondo a escrever literatura, como já apontou Inayatullah (1998), estamos apenas nos guiando com aquilo que vemos com nossos próprios olhos. A impessoalidade da terceira pessoa apareceu em muitos pontos da escrita, mas esteve sempre guiada pelos objetivos metodológicos de edificar uma pesquisa a partir de meus afetos e de minhas emoções. É um encontro constante, com nós mesmos, quando refletimos sobre o processo de escrita. A escrita deixa de se tornar um instrumento de expressão de conhecimento para se tornar um instrumento de expressão de nós mesmos pelo conhecimento. A abordagem autobiográfica das Relações Internacionais nos guia 
por nossas próprias impressões diante dos fatos transnacionais na nossa frente. Parar e observar, escrever e revisar, tornaram-se verbos fundamentais para quem se aventura na autobiografia. Como tecelão, propondo-me a observar a vida pelos olhares alheios a mim, observei como a autobiografia das pessoas que vivem com HIV tornava-se fundamental na construção de conhecimento sobre as narrativas e as contranarrativas do HIV e da Aids. Elas escreviam a partir de elas mesmas e teciam com suas próprias palavras, despreocupadas com estilo e técnica para escrever, como as narrativas transnacionais do HIV e da Aids atingiam-nas. Manifestavam paixões, que as deixavam ora tristes, ora felizes, nas palavras que escolhiam para narrar a própria jornada. A autobiografia não veio a partir de mim, embora eu tenha guiado a pesquisa a partir de meus afetos e de minhas emoções, também de meu contato com as narrativas excludentes do HIV e da Aids, senão vieram dos outros para mim. O meu processo de mudança, de aprender e reaprender sobre o HIV e a Aids, foi fortemente contribuído pelas autobiografias que li, sublinhei e coloquei nesse trabalho. O processo de escrita em primeira pessoa nunca foi inteiramente sobre mim, sobre minhas impressões, sobre minhas decisões nas escolhas das palavras e nos rumos tomados ao longo desse tempo escrevendo. O processo de escrita em primeira pessoa foi sobre as vidas alheias sobre mim, sobre histórias que não vivi, mas ouvi atentamente o que o outro ouviu com seus próprios ouvidos. Não se tratou apenas de ver aquilo que não vimos e não vivemos, senão englobou todas as descrições possíveis dos sentidos dessa experiência: os ouvidos atentos aos murmúrios, à televisão narrando a epidemia de HIV, aos médicos nos hospitais, aos monitores cardíacos, às músicas cantadas; o tato atento ao toque, aos abraços, à violência física sofrida, às agulhas, às anamneses; o olfato atento ao cheiro hospitalar, à vida normal urbana, aos suores; o paladar atento às medicações que surgiam e traziam esperança.

A abordagem autobiográfica e autoetnográfica das Relações Internacionais permitem abrir caminhos outros na construção do conhecimento, e na construção dos sujeitos construtores também de conhecimento, ao trazer os eventos transnacionais e internacionais como íntimos às experiências singulares e próprias. Viver intrinsicamente a uma guerra, a uma crise, a uma epidemia global, a uma pandemia, e transformar os afetos e as emoções geradas a partir desses encontros é repensar como o conhecimento também pode ser formulado na disciplina, a partir de nós mesmos. Não se trata ainda de desprezar todas as outras abordagens 
positivistas que se desfazem da intimidade do pesquisador, porque a academia se constrói a partir de metodologias possíveis, a partir de visões concretas e que atendam a necessidade de construir verdades na ciência. Não é sobre escrever literatura. É sobre abranger a inclusão de metodologias outras na disciplina e compreender que o sujeito também se faz presente no internacional e que possui voz e a manifesta em palavras escritas.

A segunda reflexão se refere a minha participação como tecelão de narrativas, responsável por escolher as narrativas autobiográficas que são apresentadas na pesquisa, além de colher outros trabalhos para costurar pensamentos e relacioná-los com as narrativas autobiográficas expostas, refleti também sobre a construção das narrativas e das contranarrativas do HIV e da Aids. Dividi-as em algumas seções ao longo da pesquisa, principalmente diferenciando quais eram e como se produziam as narrativas transnacionais do HIV e da Aids. Desse encontro, explorei as narrativas autobiográficas dos sujeitos que entraram em contato com essas narrativas e sofreram com o processo de fronteira gerado pelas narrativas. A fronteira da exclusão e inclusão tornou-se fundamental para a construção também das contranarrativas, pois ao excluir esses sujeitos da sociedade moralmente aceita, eles se uniam e ressignificavam as narrativas, produzindo contranarrativas da infecção. As contranarrativas surgem como movimento de ressignificação pelas pessoas que não aceitam as epidemias narrativas de exclusão do sujeito, de estigmatização de sua existência, de desumanização por viver com HIV. As contranarrativas surgem a partir do encontro do sujeito com as narrativas. Eles as ressignificam por não as acolher como explicadoras de uma realidade, senão como motivadoras de uma degradação social. As narrativas que excluem não se separam das contranarrativas que incluem. Embora possa parecer antagônica essa relação, de narrativas e contranarrativas, é importante ressaltar que elas não se excluem. Ou seja, a existência da ressignificação por meio das contranarrativas não apaga a propagação potencial das narrativas, que ainda existem em partes da sociedade. $\mathrm{O}$ que me cabe é compreender que somos responsáveis também em manifestar as contranarrativas do HIV e da Aids sempre que possível e mostrarmos aos outros que o senso comum sobre o HIV e a Aids, muitas vezes baseado nas narrativas da infecção, mostra-se excludente. As narrativas manifestam afetos e emoções sobre o sujeito individual e coletivo, e desse encontro, a urgência das contranarrativas se mostra sempre presente, ou se mostra desnecessária. Ressignificar não é uma 
manifestação afetiva natural a todos nós. É um verbo que precisa de sujeito para colocá-lo em ação.

A terceira reflexão, brevemente mencionada no parágrafo anterior, abrange os efeitos de fronteiras criados pelas narrativas do HIV e da Aids e de como esses efeitos excluem os sujeitos individuais da coletividade. Parte dessa interpretação se deve à abordagem extensivista do Estado no controle da epidemia ao qualificar quem eram as pessoas suscetíveis ao HIV e à Aids, denominando-as de "grupos de risco". Com efeitos nítidos das narrativas transnacionais, o grupo dos $5 \mathrm{H}$ nos Estados Unidos e os "grupos de risco" no Brasil produziam efeitos muito semelhantes: determinar quem eram as pessoas perigosas à sociedade. Nessa ideia de contaminação, de ser contagiante para a sociedade, essas pessoas eram estigmatizadas e passaram a cultivar segredos sobre o status sorológico. Quando o corpo indicava os efeitos das infecções oportunistas já na manifestação da Aids, o corpo se mostrava visivelmente infectado e o segredo já era difícil de manter. As narrativas de doença enigmática para os médicos e para os cientistas propuseram fronteiras de distanciamento dessas pessoas: não se sabia o que era nem como se transmitia. Porém, esse efeito de fronteira, de exclusão e distanciamento dessas pessoas, continuou mesmo com a descoberta do HIV. Ficou construído no imaginário social, com a ajuda das narrativas midiáticas, a constante ideia de enigma e de morte. Mostrava-se e falava-se de morte todos os dias. A Aids virou morte. O HIV virou morte. E mesmo com os antirretrovirais, esses efeitos de fronteira, de começar a incluir a vida normal com o tratamento contínuo, não se desfizeram. As narrativas autobiográficas mostraram que as primeiras reações à descoberta sorológica, mesmo em uma época com antirretrovirais efetivos e sem grandes efeitos adversos, a imagem vinda à cabeça era de mistério, de morte, de exclusão, de medo. Os afetos e as emoções manifestavam sobre o sujeito a partir das narrativas, a partir do que ele sabia sobre o HIV e a Aids. A economia afetiva - a manifestação múltipla de afetos e emoções - impactava totalmente a capacidade de agir das pessoas diante das narrativas, ou as impulsionava à produção de uma realidade outra. Porém, não se pode dizer que as narrativas impactam somente as pessoas que vivem com HIV, porque a orientação de afetos tristes dessas narrativas também impacta às pessoas de suas comunidades afetivas, às pessoas que compreendem os efeitos de exclusão dessas narrativas. $\mathrm{O}$ sujeito individual e 
coletivo se impacta com as narrativas do HIV e da Aids, assim como se mobiliza à construção da ressignificação narrativa.

A quarta reflexão é sobre a ressignificação. As narrativas do HIV e da Aids foram ilustradas ao longo do segundo capítulo. Vimos que as epidemias narrativas foram desenhadas a partir de processos narrativos de outras doenças também, como a peste bubônica, o câncer, a sífilis, a tuberculose, por exemplo. A ilustração de uma sociedade contaminada, ao invés de nomear a infecção pelo HIV, representa parte dessas narrativas, principalmente retomando os fluídos corporais como venenosos e responsáveis por contaminar. O corpo contaminado é o corpo marcado, o corpo excluído. A narrativa da contaminação representa e divide a sociedade em corpos contaminados e corpos puros. Os corpos puros são moralmente cristãos, heterossexuais e não apresentam nenhum desvio à heteronormatividade. Enquanto os corpos contaminados são ilustrados como alienígenas, alheios à sociedade, com sexualidades desviantes, com tendência à injeção de substâncias ilícitas. Cresceu a percepção de corpos descartáveis com o HIV, porque a infecção se construiu nas margens da sociedade e sua narrativa reforçava a essa posição. Não se falavam de vetores ou práticas vulneráveis da epidemia. Falava-se sobre rostos e designava grupos com rostos similares. A Peste gay. O câncer rosa. Novamente a morte. São as narrativas permanentes. Narrativas sempre formadas pelas figuras de linguagem: metáforas e metonímias. Constituíram elementos importantes para as narrativas e continuam a representar o imaginário da infecção.

Mas em contato com essas narrativas, a ressignificação surge como movimento impulsionado pelas pessoas que não aceitam essas narrativas degradantes. O processo de rejeitar as narrativas do HIV e da Aids se aglutina ao processo de dar significados outros ao que se ouviu. Ao descobrir grupos de riscos, ressignifica-se e explica-se que qualquer um está susceptível à infecção, desde que esteja exposto às práticas vulneráveis. A narrativa que se criou, é reinterpretada com a intenção de desfazer os efeitos de fronteiras e retirar a culpa sobre determinados grupos colocados às margens da sociedade. Ao descobrir associações metonímicas que HIV é Aids, explica-se que HIV, se não tratado, inclui a pessoa no estado social e de saúde da Aids, além de reforçar a ideia de que esse processo não é instantâneo, leva-se um tempo para essa transição. Por isso a importância dos antirretrovirais, de impedir que o HIV se torne Aids e que a Aids se torne morte. Ressignificar a morte talvez seja um dos grandes objetivos principais das contranarrativas do HIV 
e da Aids. Trata-se de explicar exaustivamente a urgência de manter um tratamento contínuo de antirretrovirais e também trabalhar na frente de testagem e acolher às pessoas que descobrem viver com HIV antes que ocorra essa transição para a Aids. É sobre compreender a vida, nada mais além disso. É reforçar a importância da vida em oposição às histórias antigas de morte generalizada por causa da Aids. Embora ainda seja uma realidade, a morte em decorrência de infecções oportunistas, devese preencher as lacunas globais que impedem que um tratamento existente e efetivo chegue à pessoa que vive com HIV.

É um constante processo de ressignificação que se manifesta no processo de rejeição das narrativas do HIV e da Aids. O efeito principal da ressignificação é que um dia as narrativas estigmatizantes do HIV e da Aids deixem de produzir sentido para grande parte da população. As narrativas precisariam ser vistas como parte constituinte do começo da epidemia e não ainda como persistentes para ilustrar essa realidade epidêmica quatro décadas depois dos primeiros casos. A única persistência que nos cabe é sobre o processo de ressignificação. É persistindo sobre recontar essa epidemia que seremos capazes de impulsionar narrativas que acolhem e que nos fortalecem.

Por fim, a última reflexão que quero propor é muito mais intimista. E não precisamos todos dessa intimidade com a pesquisa? Não necessariamente precisamos entregar nossas impressões e nossas afecções na escrita da pesquisa de tudo que nos moveu ao longo do processo de construção. A intimidade nos é única e singular. Não experimentamos intimidades idênticas, embora possamos compartilhar de intimidades próximas. Optar por expandir a nossa intimidade para a pesquisa, a fim de nos tirarmos o fardo de carregar o mundo inteiro, pode parecer saudável quando buscamos por metodologias outras. A autobiografia, a autoetnografia, tecer narrativas e contranarrativas me mostraram o quanto a intimidade com a nossa escrita pode nos proporcionar bons frutos e pode propor à academia construções válidas de ciência. Se somos seres vivos e estamos suscetíveis a sentirmos as mais diversas manifestações afetivas e emocionais em contato com nossos objetos de pesquisa, por que seríamos menos cientistas se expressarmos nossas opiniões sinceras, em primeira ou em terceira pessoa, em nossas pesquisas? Parece que para os positivismos, isso é inviável. Mas compreendendo a estética nas Relações Internacionais, talvez seja necessário recuperarmos os traçados humanos, até de nós mesmos, e expormos em notas de 
rodapé, parágrafos aleatórios, introduções ou considerações finais. Qual mal nos caberia se os traçados humanos presentes de nossas vivências singulares e múltiplas pudessem contribuir com o diálogo com o outro? Um outro mais próximo de nós do que imaginamos. Eu não escrevo para ser guardado em uma biblioteca virtual. Eu escrevo porque quero ser ouvido. E todos que escrevem querem ser ouvidos. É a polifonia que constrói a ciência. E claro, nenhuma reflexão minha deve ser imposta. Ver o que o outro viu com seus próprios olhos é urgente. Verdadeiramente ver com todos os sentidos. Escrever esse encontro não é necessário, mas nos impulsiona - ao menos me impulsionou - à desfeita das fronteiras que nos separam.

Além das contribuições intimistas que a escolha da metodologia pode trazer, preciso falar que desbravar ainda mais os afetos e as emoções na disciplina de Relações Internacionais é fundamental para incluir mais espaços possíveis na pesquisa, com visões e escritas intimistas e concretas. A realidade internacional nos atravessa. Somos atingidos afetivamente pelo noticiário internacional, pelo impacto do Internacional na realidade política interna, pelas decisões políticas internas conectadas com interesses transnacionais, em resumo, estamos a todo momento sentindo o internacional, seja de uma forma que não compreendemos muito bem, seja de uma forma que nos é possível toda essa expressão.

A relação dos estudos linguísticos, estilísticos, de comunicação em minha dissertação é um dos pontos centrais que busquei contribuir com a disciplina. Precisamos notar o impacto que as comunicações transnacionais geram no cotidiano e como elas são capazes de construir e determinar vidas. As narrativas e as contranarrativas buscaram ilustrar o poder da comunicação em vidas humanos e certamente estará marcado em mim como continuação de pesquisa. Porém, cabeme assinalar que esse processo de narrativa e de contranarrativa não é exclusivo às Relações Internacionais. Refletir como a nossa realidade é narrada, as posições tomadas e direcionadas pelo ato de narrar uma realidade, é fundamental para construirmos nossas posições no mundo. A partir das narrativas transnacionais, consegui perceber como o HIV e a Aids foram tratados nos Estados Unidos e no Brasil. A comunicação é fundamental na construção de realidades e a forma como o HIV e a Aids foram construídos nos revela o trabalho que teremos para reconstruir narrativas de inclusão.

$\mathrm{Na}$ construção das pesquisas, ainda inquietante para mim é entender se a contextualização é necessária. Posso falar de HIV e de Aids somente a partir das 
contranarrativas, sem revisitar o passado/presente das narrativas da exclusão? Uma pergunta sem respostas ainda e talvez nem haja respostas corretas ou erradas. A minha decisão de trazer as narrativas do HIV e da Aids serviu de base para apoiar as reflexões e os exemplos de contranarrativas. Entretanto, somente a partir da contextualização eu fui capaz de entender que, em partes, eu reproduzia e ilustrava quais eram as narrativas para explicar quais contranarrativas emergiram. Poderia ter optado por um caminho que partisse das contranarrativas e buscar não reavivar, ou mostrar por uma primeira vez para quem pouco sabe sobre a epidemia de HIV, as narrativas. Mas como pesquisador, que reflete constantemente sobre os rumos iniciais e finais de sua pesquisa, assumi a necessidade de contextualizar as narrativas para entendê-las em suas multiplicidades. Assumindo a primeira posição a partir das contranarrativas, as futuras pesquisas me levarão a novos olhares.

As considerações finais também são momentos de despedidas, de partidas, de abandonos. Uma vez escrito, tudo traduzido sobre você nesse instante se marca no tempo. Ser íntimos de nossas pesquisas nos dificulta a terminar e nos impõe sérias dificuldades para formular como ela deve terminar. Da mesma forma que comecei, pretendo terminar. Essa dissertação não é uma ficção. As palavras e a escrita dela terminam aqui, mas eu espero que todos os afetos e as emoções manifestadas em mim, e nos prováveis leitores dessa pesquisa, possam nos mover a uma realidade outra. Uma realidade em que somos todos incluídos. Incluídos na simples e mais bela manifestação de acolher as múltiplas vivências. 


\section{Referências Bibliográficas}

AHMED, Sara. The Cultural Politics of emotion. Nova lorque: Routledge, 2014.

AMY, Lori. Listening for the elsewhere and the not-yet: Academic labor as a matter of ethical witness. In: INAYATULLAH, Naeem. Autobiographichal International Relations - I, IR. Londres: Routledge, 2010.

ARADAU, Claudia; HUYSMANS, Jef. Critical Methods in International Relations: The politics of the techniques, devices and acts. Londres: Queen Mary University of London, 2014.

BARATA, Germana Fernandes. A primeira década da Aids no Brasil: o Fantástico apresenta a doença ao público (1983 a 1992). São Paulo: Universidade de São Paulo, Departamento de História, 2006.

BARDHAN, N. Transnational AIDS-HIV News Narratives: A Critical Exploration of Overarching Frames. Mass Communication and Society, v.4, n.3, p. 283-309, 2001.

BAXEN, J. Using narratives to develop a hermeneutic understanding of HIV/AIDS in South Africa. Compare: A Journal of Comparative and International Education, v.38, n.3, p. 307-319, 2008.

BLEIKER, Roland. The Aesthetic Turn in International Political Theory. Millennuium: Journal of International Studies, v.30, n.3, p. 509-533. Londres, 2001.

BRAGANÇA, Lucas; GOVEIA, Fábio. Narrativas do HIV/Aids no Twitter e suas correlações com a juventude brasileira contemporânea. Intercom: Sociedade Brasileira de Estudos Interdisciplinares da Comunicação. Curitiba, 2017.

BRASIL. Ministério da Mulher, da Família e dos Direitos Humanos; Ministério da Saúde. Prevenção da Gravidez na Adolescência, 2019. Disponível em: <http://portalarquivos.saude.gov.br/campanhas/prevencao agravidez/?fbclid=lwAR2V7hKuxKHa4F7BSqGgfZ6mpk_MfzJtd957xozpy 675q9NYQylLQGI_Kfl\#/>. Acesso em: 19 maio. 2020.

BRETON, David Le. Antropologia dos Sentidos. Petrópolis: Vozes, 2016. 
CARTA para Além dos Muros (Documentário). Direção: André Canto. Produção: André Canto. Roteiro: André Canto; Gabriel Estrela; Ricardo Farias; Gustavo Menezes. São Paulo: Canto Produções, 2019.

CARVALHO, Carlos Alberto de. Afetar e ser afetado pelo acontecimento: coberturas jornalísticas da Aids e impactos sociais. Intercom: Revista Brasileira de Ciências da Comunicação, v.38, n.2. São Paulo, 2015.

CHAN, Stephen. Accidental scholarship and the myth of objectivity. In: DAUPHINEE, E.; INAYATULLAH, N. Narrative Global Politics: Theory, History and Personal in International Relations. Abingdon: Routledge, 2016.

CIMINO, James. Nós gays levamos a culpa, mas os heterossexuais são responsáveis pela maioria das infecções de HIV. The Intercept Brasil, 2020. Disponível em: <https://theintercept.com/2020/09/04/hivheterossexuais-gays-preconceito/>. Acesso em: 08 de outubro de 2020.

CRENSHAW, K. Mapping the Margins: Intersectionality, Identity Politics, and Violence Against Women of Color. Stanford Law Review. v. 43, n 6 , p. 241-299. Stanford, 1991.

DAMASCENO, Éverson de Brito. et al. Algo tão simples de viver e controlar, mas difícil de compartilhar e defender: HIV/Aids, segredos e socialidades em uma rede social on-line. Botucatu: Interface, 2019.

DAUPHINEE, E. The ethics of autoethnography. Review of International Studies, v. 36, n. 03, p. 799-818, 2010.

DAUPHINEE, E.; INAYATULLAH, N. Narrative Global Politics: Theory, History and Personal in International Relations. Abingdon: Routledge, 2016.

DAVIES, S. E. What contribution can International Relations make to the evolving global health agenda. International Affairs, v. 86, n. 5, p. 11671190, 2010.

DOURADO, Inês; SANTOS, Melquisedec; SILVA, Luis A. V. Entre idas e vindas: histórias de homens sobre seus itinerários ao serviço de saúde para diagnóstico e tratamento de HIV/Aids. Physis. Revista de Saúde Coletiva, v.25, n.3, p. 951-973. Rio de Janeiro, 2015.

DUARTE, Felipe Mateus; NETTO, Gilberto Rios Alves; SILVA, Luís Augusto Vasconcelos da. Sociabilidades "positivas" em rede: narrativas de jovens em torno do HIV/Aids e suas tensões cotidianas. Physis. Revista de Saúde Coletiva, v.27, n.2, p. 335-355. Rio de Janeiro, 2017. 
EDKINS, Jenny. Objects Among Objects. In: INAYATULLAH, Naeem. Autobiographichal International Relations - I, IR. Londres: Routledge, 2010.

ELBE, S. HIV/AIDS and the Changing Landscape of War in Africa. International Security, v.27, n.2, p. 159-177, 2002.

ELBE, S. Bodies as Battlefields Toward the Medicalization of Insecurity. International Political Sociology, v.6, n.3, p. 320-322, 2012.

EPSTEIN, Charlotte. The Power of Words in International Relations: Birth of an Anti-Whaling Discourse. Cambridge: Massachusetts Institute of Technology Press, 2008.

PESSOA com HIV é despesa para todos no Brasil, diz Bolsonaro. EXAME Disponível em: <https://exame.com/brasil/pessoa-com-hiv-e-despesapara-todos-no-brasil-diz-bolsonaro/>. Acesso em: 19 mar. 2020.

EZZY, D. Illness narratives: time, hope and HIV. Social Science \& Medicine, v.50, n.5, p. 605-617, 2000.

FERREIRA, Aurélio Buarque de Holanda. Mini Aurélio: o dicionário de língua portuguesa. Coordenação de edição Marina Baird Ferreira, 8. ed. Curitiba: Positivo, 2010.

FREEDMAN, J.; POKU, N. The socioeconomic context of Africa's vulnerability to HIV/AIDS. Review of International Studies, v.31, n.04, 2005.

FRISSO, G. L. O HIV/Aids nas Relações Internacionais: saúde global e cooperação no caso da Sociedade Moçambicana de Medicamentos. Foz do Iguaçu: Relações Internacionais e Integração, 2018. 98p.

FRISSO, G. L. O regime político da heterossexualidade e a migração sexual. Revista Espacialidades, v.17, n.1, p. 387-412, 2021.

GARCIA, Othon M. Comunicação em prosa moderna. 27. ed. Rio de Janeiro: FGV Editora, 2010.

GILBERT, Jeremy. Common Ground: Democracy and Collectivity in an Age of Individualism. Londres: Pluto Press, 2013.

GRMEK, Mirko. O enigma do aparecimento da Aids. Estudos avançados IEA-USP, v.9, n.24, São Paulo, 1995. 
GRUBE, A.; BOEHME-DUERR, K. AIDS in International News Magazines. Journalism Quarterly, v.65, n.3, p. 686-689, 1988.

HE, B. Global social justice at the WTO: The role of NGOs in constructing global social contracts. International Affairs, v.83, n.04, p. 707-727, 2007.

HEINZEN, B. The politics of AIDS and International cooperation in response to AIDS. International Affairs, v.73, n.01, p. 170-170, 1997.

HELLER, J. Rumors and Realities: Making Sense of HIV/AIDS Conspiracy Narratives and Contemporary Legends. American Journal of Public Health, v.105, n.01, p. 43-50, 2015

HOOKS, bell. Theory as Liberatory Practice. Yale Journal of Law \& Feminism, 1992.

INÁCIO, E. C. Carga zerada: HIV/AIDS, discurso, desgaste, cultura. Via Atlântica, v.29, p. 479-505, 2016

INAYATULLAH, Naeem. If Only You Could See What I have Seen with Your Eyes: Staging an Encounter Between Social Science and Literature. Looking at the World Through Non-Western Eyes. Columbia: University of South Carolina, 1998.

INAYATULLAH, Naeem. Autobiographichal International Relations - I, IR. Londres: Routledge, 2010.

JESUS, Diego Santos Vieira; TÉLLEZ, Claudio Andrés. Concerto para nenhuma voz? Arte e Estética no estudo das Relações Internacionais. Examãpaku, v.07, n.03. Curitiba, 2014.

KIND, Luciana; SOUZA, Emilene Araujo. Vidas que seguem: narrativas ficcionais de jovens vivendo com HIV/Aids. Psicologia em Revista, v.23, n.03. Belo Horizonte, 2017.

KOBLENTZ, G. D. Biosecurity Reconsidered. Calibrating Biological Threats and Responses. International Security, v.34, n.04, p. 96-132, 2010.

KOSCHUT, Simon. et al. The Forum: Discourse and Emotions in International Relations. International Studies Review, v.00. p. 1-27. Oxford, 2017. 
LERAY, Wallace. Alô, Ana Paula Valadão: vem aprender sobre HIV e Aids e parar de ser preconceituosa. São Paulo: Catraca Livre, 15 set. 2020. Disponível em: <https://catracalivre.com.br/saude-bem-estar/alo-anapaula-valadao-vem-aprender-sobre-hiv-e-aids-e-parar-de-serpreconceituosa/>. Acesso em: 05 out. 2020.

LEWIS, Isobel. Not funny in the 1980s, not funny now: Dave Chappelle criticized for making Freddie Mercury joke on SNL. Independent, 2020. Disponível em: <https://www.independent.co.uk/arts-entertainment/tv/ news/dave-chappelle-snl-freddie-mercury-aids-trump-coronavirusb1719689.html>. Acesso em: 22 abr. 2021.

LITTLEMORE, Jeannette. Metonymy: Hidden Shortcuts in Language, Thought and Communication. Cambridge: Cambridge University Press, 2015.

MAIA, Miguel Angelo Barbosa; NEVES, Claudia Abbês Baêta. Qual a potência do apoio institucional no campo da saúde pública? Interface, v.18, p. 21-31. Botucatu, 2014.

MASSUMI, Brian. Parables for the virtual: Movement, Affect, Sensation. Londres: Duke University Press, 2002.

MATTEO, Giovanna de. O paciente mais demonizado da história: a melancólica saga de Gaetan Dugas. Aventuras na História, Uol, 2020. Disponível em: <https://aventurasnahistoria.uol.com.br/noticias/ reportagem/o-paciente-mais-demonizado-da-historia-a-melancolica-sagade-gaetan-dugas.phtml>. Acesso em: 10 mar. 2021.

McINNES, C.; LEE, K. Health, security and foreign policy. Review of International Studies, v. 32, n. 01, p. 5, 2006.

McINNES, C.; ROEMER-MAHLER, A. From security to risk reframing global health threats. International Affairs, v.93, n.06, 2017.

McINNES, C.; RUSHTON, S. HIV/AIDS and securitization theory. European Journal of International Relations, v.19, n.01, p. 115-138, 2012.

McINNES, C. HIV, AIDS and conflict in Africa why isn't it (even) worse. Review of International Studies, v.37, n.02, p. 485-509, 2010.

MONTEIRO, José Lemos. A Estilística: Manual de análise e criação do estilo literário. Petrópolis/RJ: Vozes, 2009. 
NASCIMENTO, Dilene Raimon do. A construção de si: uma narrativa em torno da experiência da AIDS. Revista de História Regional, v.3, n.02, p. 157-166, 1998.

NUNES, J. Questioning health security Insecurity and domination in world politics. Review of International Studies, v. 40, n.05, p. 939-960, 2014.

OWEN, G.; CATALAN, J. "We never expected this to happen": narratives of ageing with HIV among gay men living in London, UK. Culture, Health \& Sexuality, v.14, n.01, p. 59-72, 2012.

PASSOS, E.; BARROS, R. B. de. Pistas do Método da Cartografia, pesquisa-intervenção e produção da subjetividade. Rio de Janeiro: Editora Sulina, 2009.

PICQ, Manuela L. Simultaneous Translation, Finding my core in the periphery. In: DAUPHINEE, E.; INAYATULLAH, N. Narrative Global Politics: Theory, History and Personal in International Relations. Abingdon: Routledge, 2016.

PIN-FAT, Véronique. Writing narrative as ethics and philosophy in International Relations: Reflections on a difficulty in writing a research monograph. Journal of Narrative Politics, v.03, n.01, p. 27-37, 2016.

PRINS, G. AIDS and global security. International Affairs, v.80, n.05, p. 931-952, 2004.

PUNTER, David. Metaphor. The New Critical Idiom. Abingdon: Routledge, 2007.

REGINA, Cláudia. Mirko Drazen Grmek. Instituto de Estudos Avançados da Universidade de São Paulo, 2013. Disponível em: <http://www. iea.usp.br/pessoas/pasta-pessoam/mirko-drazen-grmek>. Acesso em: 07 dez. 2020.

RUIZ, M. V. Border Narratives, HIV/AIDS, and Latina/o Health in the United States: A Cultural Analysis. Feminist Media Studies, v.2, n.01, p. 37-62, 2002.

RUTH, Leys. The Turn to Affect: A Critique. Chicago: The University of Chicago, 2011.

SAFATLE, V. O circuito dos Afetos, corpos políticos, desamparo e o fim do indivíduo. São Paulo: Cosac Naify, 2015. 
SHAFFER, V. A.; ZIKMUND-FISHER, B. J. All Stories Are Not Alike. Medical Decision Making, v.33, n.01, p. 4-13, 2012.

SILVA, F. R.; GUEDES, R. S. A mídia impressa e a construção narrativa sobre a AIDS no Brasil no final do século XX: Uma relação perigosa. Rev. C \& Trópico, v.44, n.01, p. 121-140, 2020.

SONTAG, Susan. A Doença como Metáfora. São Paulo: Ed. Graal, 1984.

SONTAG, Susan. AIDS e suas Metáforas. São Paulo: Ed. Graal 1989.

SPINOZA, B. de. Ethics. Oxford and New York: Oxford University Press, 2000.

SPIVAK, G. C. Pode o subalterno falar? 1. ed. Belo Horizonte: Editora da UFMG, 2010.

SQUIRE, C. Neighbors Who Might Become Friends: Selves, Genres, and Citizenship in Narratives of HIV. The Sociological Quarterly, v.40, n.01, p. 109-137, 1999.

STEVENS, P. E.; TIGHE DOERR, B. Trauma of discovery: Women's narratives of being informed they are HIV-infected. AIDS Care, v.9, n.05, p. 523-538, 1997.

TIMERMAN, Artur; MAGALHÃES, Naiara. Histórias da Aids. São Paulo: Ed. Autêntica, 2015.

UNAIDS. Guia de Terminologias do UNAIDS. 2017.

UNAIDS. Estatísticas, 2020. Disponível em: <https://unaids.org.br/ estatisticas/>. Acesso em: 30 mar. 2021.

WINSKELL, K.; OBYERODHYAMBO, O.; STEPHENSON, R. Making sense of condoms: Social representations in young people's HIV-related narratives from six African countries. Social Science \& Medicine, v.72. n.06, p. 953-961, 2011. 